\title{
Remarkable teleostean fishes from the Late Jurassic of southern Germany and their phylogenetic relationships
}

\author{
Gloria Arratia ${ }^{1}$ \\ With 22 figures and 5 tables
}

\begin{abstract}
Complete descriptions, as preservation permits, are provided for new Late Jurassic taxa (e.g., †Ascalabothrissops voelkli $\mathrm{n}$. gen. and n. sp., $\nmid$ Anaethalion zapporum n. sp., and $\nmid$ Elopsomolos frickhingeri $\mathrm{n}$. gen. and $\mathrm{n}$. sp.); the phylogenetic positions of these taxa are given, as well as an evaluation of the European teleosts during the Late Jurassic.

The relationships among certain fossil and extant teleosts are evaluated based on 191 unweighted morphological characters by using cladistic principles. The results suggest that $\nmid$ Ascalabothrissops $\mathrm{n}$. gen. from the Kimmeridgian of Schamhaupten is the sister-taxon of $\nmid$ Pachythrissops from the Tithonian of Bavaria, and consequently is an ichthyodectiform. $\dagger$ Anaethalion zapporum n. sp., an elopiform, stands in an unresolved polytomy with $\dagger A$. angustus, $\dagger A$. knorri, and a clade formed by $\dagger A$. angustissimus and more advanced elopiforms. The new results confirm Arratia (1997) that $\dagger$ Anaethalion, as presently understood, is a paraphyletic taxon. †Elopsomolos frickhingeri $\mathrm{n}$. gen. and n. sp. forms a polytomy with †Elopsomolos sp. 1 and 3 , and [Elops + Megalops]. Monophyly of the Kimmeridgian and Tithonian genus $\dagger$ Elopsomolos is not certain.

Following the new phylogenetic hypothesis, that includes new taxa and new characters, the elopomorphs stand as the primitive sister-group of osteoglossomorphs and more advanced teleosts. The new information does not affect the phylogenetic position of the main extant teleostean clades and confirms previous results by Arratia (1991, 1996, 1997, 1999).

The analysis of the elopiforms through time shows that the group had an important radiation during the Late Jurassic, to be replaced by new genera and species during the Cretaceous, and again during the Cenozoic. From numerous genera living in the past, elopiforms are represented now by two genera, Elops and Megalops.
\end{abstract}

Key words: Fishes, Teleostei, †Ichthyodectiformes, Elopiformes, Late Jurassic, phylogeny.

\section{Zusammenfassung}

Soweit es die Erhaltung zulässt, werden vollständige Beschreibungen der drei neuen spätjurassischen Taxa $\nmid$ Ascalabothrissops voelkli $\mathrm{n}$. gen. et $\mathrm{n}$. sp., $\nmid$ Anaethalion zapporum n. sp., und †Elopsomolos frickhingeri n. gen. et n. sp. gegeben. Die phylogenetische Stellung dieser Taxa als auch anderer spätjurassischer europäischer Teleosteer ist analysiert.

Die Verwandtschaftsbeziehungen innerhalb einiger fossiler und rezenter Teleosteer wurden auf der Basis von 191 nicht gewichteten morphologischen Merkmalen mit Hilfe der kladistischen Methode evaluiert. Als Ergebnis zeigt sich, dass $\nmid$ Ascalabothrissops $\mathrm{n}$. gen. aus dem Kimmeridgium von Schamhaupten das Schwestertaxon von †Pachythrissops und damit ein Ichthyodectiformer ist. $\nmid$ Anaethalion zapporum n. sp., ein Elopiformer, steht in einer nicht auflösbaren Polytomie mit $\nmid A$. angustus, $\dagger A$. knorri, und einer Gruppe gebildet aus $\dagger A$. angustissimus und weiter fortgeschrittenen Elopiformen. Die neuen Ergebnisse bestätigen Arratia (1997), dass $\nmid$ Anaethalion, wie zur Zeit umgrenzt, ein paraphylethisches Taxon darstellt. $\dagger$ Elopsomolos frickhingeri $\mathrm{n}$. gen. et $\mathrm{n}$. sp. bildet eine Polytomie mit †Elopsomolos sp. 1 und 3, und [Elops + Megalops]. Die Monophylie der Gattung $\dagger$ Elopsomolos aus dem Kimmeridgium und Tithonium ist nicht gesichert.

Nach der neuen phylogenetischen Hypothese, die neue Taxa und neue Merkmale einbezieht, sind die Elopomorphen die primitive Schwestergruppe der Osteoglossomorphen und weiter fortgeschrittener Teleosteer. Die neuen Ergebnisse beeinflussen die phylogenetische Stellung der rezenten Hauptgruppen der Teleosteer nicht und bestätigen frühere Ergebnisse von Arratia $(1991,1996,1997,1999)$.

Die Analyse der Elopiformen zeigt, dass die Gruppe eine bedeutende Radiation im Spätjura erlebte; neue Gattungen und Arten traten in der Kreide auf und dann wieder im Känozoikum. Im Gegensatz zu den zahlreichen fossilen Gattungen sind die Elopiformen heute nur durch zwei Gattungen vertreten, Elops und Megalops.

Schlïsselwörter: Fische, Teleostei, $\nmid$ Ichthyodectiformes, Elopiformes, Oberer Jura, Phylogenie.

1 Museum für Naturkunde, Institut für Paläontologie, Invalidenstr. 43, D-10115 Berlin, Germany. Received April, accepted June 2000 


\section{Introduction}

The fossiliferous localities of Bavaria, southern Germany, represent without doubt the richest fossil $(\dagger)$ fish localities in the world. They are a succession of Upper Jurassic localities (Fig. 1) of different age (Kimmeridgian. Tithonian Malm Z2, and Tithonian Malm Z3). Unfortunately. the specimens have often been identified simply as "Solnhofen limestone" or "Solnhofen" in museum collections.

Fishes from the Upper Jurassic of Bavaria have been already studied over 200 years. The first illustrations appeared in the work of Knorr (1755: pls. 23: figs 2, 3, 26a: figs 1-4, 28: fig. 2 , and 29: figs 2-4). Later, fishes illustrated by Knorr (1755) were given names by Blainville (1818) (for details see Arratia 1997: 61).

Numerous publications with descriptions of new genera and species of teleosts from the region were produced in the 19 th century and the beginning of the 20th century (e.g.. Agassiz 1833-44, Blainville 1818, Münster 1834. 1839a, b, 1842, Wagner 1861. 1863, Vetter 1881. Woodward 1895, Eastman 1914. Biese 1927. Weitzel 1933). Among these new taxa were genera such as Thrissops, †Pachythrissops, †Ascalabos, and ${ }_{\uparrow}$ Leptolepis. All small fishes were considered under the name $\dagger$ Leptolepis, so that species such as $\nmid$ L. voithii, sprattiformis etc. were included in that genus. Unfortunately, research on the fishes was slowed down for many years because it was wrongly believed that no new information would come from the quarries of the Upper Jurassic of Bavaria.

The research by Nybelin was fundamental to changing previous interpretations of many Late Jurassic teleosts from Bavaria. He demonstrated that the genus $\dagger$ Leptolepis is restricted to the Early Jurassic. In addition, he created the genera $\lceil$ Leptolepides and $\uparrow$ Tharsis, and recognized $\uparrow A s c a-$ labos as a valid genus (Nybelin 1974). Earlier, Nybelin (1964) created the genus $\dagger$ Anaethalion for certain forms from the Upper Jurassic of Bavaria; he revisited the genus in 1967. This work was continued by revisions of Taverne on $\dagger$ Ascalabos, $\uparrow$ Allothrissops, and $\dagger$ Leptolepides (Taverne 1975a, b, 1981).

A research program on teleostean taxa of the Upper Jurassic, Malm Z2, of different localities of Bavaria was started by Arratia about 20 years ago. The research resulted in the revision of

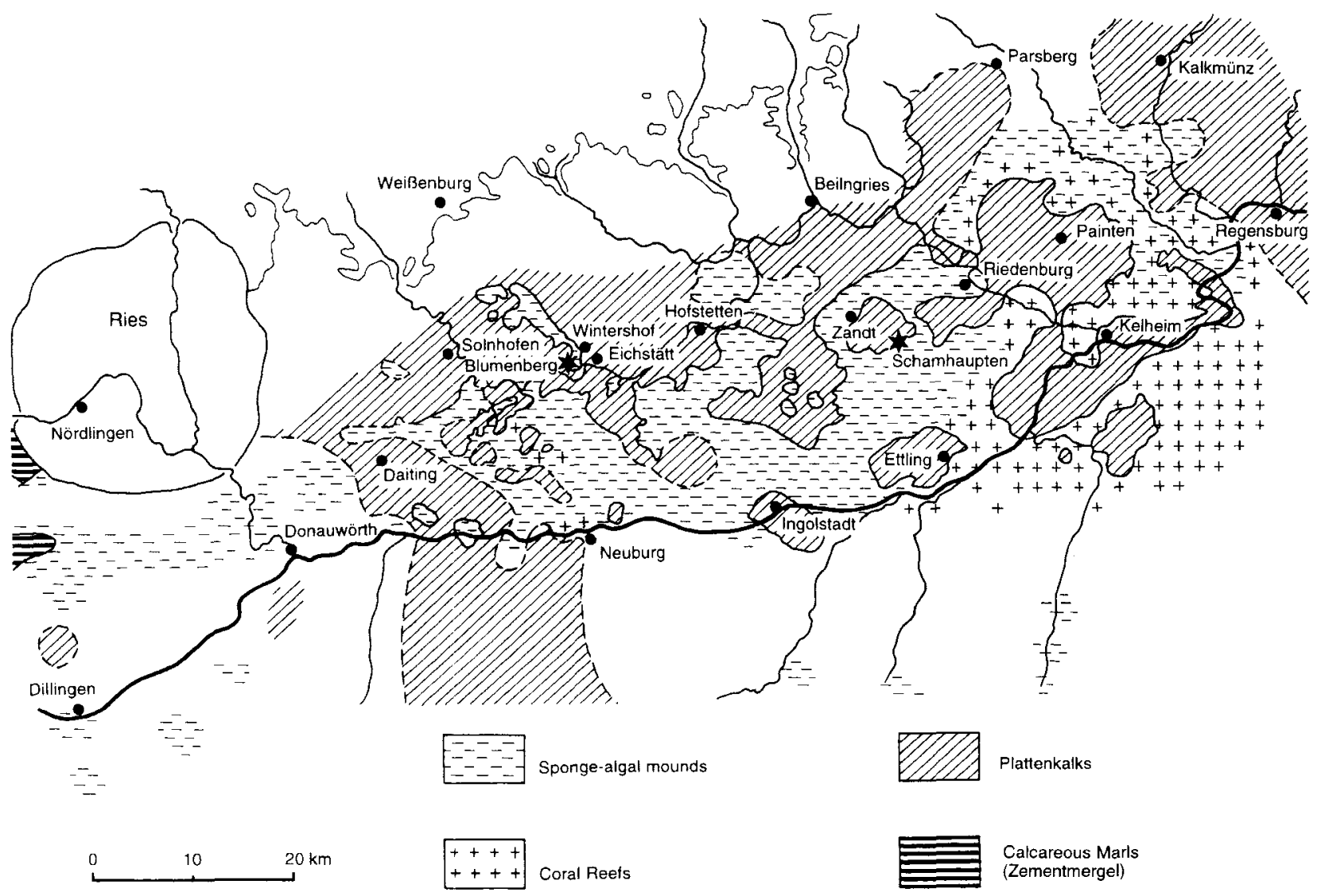

Fig. 1. Distribution of Plattenkalk basins and reef areas in the southern Franconian Alb during early Tithonian times (slightly modified from Viohl 1996). Stars represent localities bearing fishes studied herein 
$\dagger$ Anaethalion, the description of the new genera $\dagger$ Eichstaettia (Arratia 1987a) and †Orthogonikleithrus (Arratia 1987b), and detailed revisions of the genera $\dagger$ Ascalabos, $\dagger$ Pachythrissops, Elopslike fishes, $\dagger$ Leptolepides, and $\dagger$ Orthogonikleithrus (Arratia 1997). Furthermore, new localities were included so that Elops-like forms were also described from the Kimmeridgian of Schamhaupten, and probably the oldest ostariophysan from Malm Z3 of Mühlheim (Arratia 1997). Recently, new 'pholidophoriforms' belonging to the genus $\dagger$ Siemensichthys were described from the Kimmeridgian of Schamhaupten and Malm Z2 of Eichstätt, Kapfelberg, and other localities from the Solnhofen Limestone (Arratia 2000). Many of these findings have been fundamental to understanding the phylogenetic relationships of primitive teleosts. They give a new interpretation of the evolutionary history of some of the main clades of teleosts (Arratia 1996, 1997, 1999, 2000). Whereas some Late Jurassic teleosts from Bavaria are basal teleosts (e.g., $\dagger$ Tharsis, $\dagger$ Ascalabos), others represent the oldest records of the supercohort Elopomorpha (e.g., †Elopsomolos, †Anaethalion), of the so called 'salmoniforms' (e.g., †Leptolepides, †Orthogonikleithrus), and probably of the ostariophysans (e.g., $\dagger$ Tischlingerichthys).

During this long research project, I have found several specimens in museum collections which do not belong to any of the valid taxa. I waited years to find more specimens to provide a more complete description. After so many years of negative results, I decided to publish my findings as a way to stimulate new excavations in the region, and also, scientific research of the material. (Additional specimens are in the hands of some private collectors who are not willing to deposit the specimens in a museum.)

The goal of this contribution is to describe some interesting, rare teleosts recovered in recent excavations in Bavaria and material from Blumenberg that was unidentified for many years, and to determine their probable phylogenetic relationships to other teleosts.

\section{Material and methods}

The fossil material examined belongs to the institutions listed below:

BSPG, Bayerische Staatssammlung für Paläontologie und historische Geologie, München;

JM, Jura Museum, Eichstätt (SOS identifies fishes from Solnhofen Limestone and SCH from Schamhaupten);

MB, Institut für Paläontologie, Museum für Naturkunde der Humboldt-Universität, Berlin.
For outgroup taxa and comparative material of fossil and Recent teleosts examined see lists of material in Arratia (1997: 13-17, 1999: 269-273).

Methods of preparation: Most of the specimens have been mechanically prepared by the author. Specimens JM SCH30 and JM SCH85 were prepared by Mr. G. VölkI (Jura Museum, Eichstätt).

Phylogenetic methods: Several cladistic analyses following the cladistic principles (Hennig 1966. Wiley 1981) were performed using PAUP (Phylogenetic Analysis Using Parsimony) software (versions 3.1) of Swofford (1993) on a Macintosh computer to test the characters used in the diagnoses of the new taxa and to test their phylogenetic position within the Teleostei. All characters are unweighted, unordered, and considered to be simple and independent of one another (Kluge \& Farris 1969). Outgroup comparison was used (Farris 1982, Kluge 1985) to polarize hypotheses of character transformations. The polarization of characters follows Maddison et al. (1984). Different outgroups were used in the different phylogenetic analyses; they are stated in the matrices and lists of characters included below (Appendices 1,2).

Terminology: Some of the terminology of actinopterygian dermal cranial bones implying homology with other osteichthyans is unsatisfactory, and a combined terminology is sometimes used. Few authors have addressed the question of homology of certain head bones across major actinopterygian groups (e.g., Jollie 1962, Schultze \& Arsenault 1985, Schultze 1993; for more references see Arratia \& Schultze 1999). Following the homologization of dermal skull bones in osteichthyans, I identify the so-called frontal in actinopterygians as the parietal and the so-called parietal as the postparietal throughout this paper.

For the terminology of the caudal skeleton, I follow Arratia \& Schultze (1992). Many adult fossil and extant teleosts have two ural centra; consequently, a caudal skeleton with two ural centra is commonly called a diural caudal skeleton. However, numerous teleosts present more than two ural centra during ontogeny and in addition, the two ural centra are not always homologous (for details see Schultze \& Arratia 1988, 1989 and Arratia \& Schultze 1992). The early ontogenetic condition of the fossils studied here is unknown; therefore, I am unable to determine whether the so-called ural centrum 1 is formed by the fusion of ural centrum $!$ and 2 (in polyural terminology), or it is only formed by ural centrum 2 as it is observed in numerous extant teleosts. I face the same problem with the so-called ural centrum 2 that may be formed by a fusion of ural centra $(3,4$, etc.), or it may correspond to ural centrum 4 alone. Due to the fact that I am uncertain about the homology of the ural centra in the fossils described below, I prefer to identify them as 'first' and 'second' ural centra, without compromising the presence of ural centrum $1,2,3$, etc.

\section{Systematic paleontology}

Division Teleostei sensu Arratia, 1999

Order $\dagger$ Ichthyodectiformes Bardack \& Sprinkle, 1969

Family? Allothrissopidae Patterson \& Rosen, 1977

\section{$\dagger$ Ascalabothrissops n. gen.}

Diagnosis (based on a combination of features): Small fusiform teleost with dorsal fin origin placed posterior to half of standard length, 
almost directly over anal fin [*]. Entopterygoid with conical teeth. Narrow preopercle with broad sensory tubules reaching the posteroventral margin of bone. With 41 vertebrae, about 19 caudals (including preural centrum 1) [\%]. Neural spines of abdominal vertebrae short. Slender. long epipleural bones lateral to the last rib and first haemal arches. Caudal vertebral autocentra thick and with smooth surface [\%]: with narrow neural and haemal arches fused to the middle region of each centrum in caudal region [*]. Caudal vertebrae with neural and haemal spines narrow and long including that of preural centrum $2[*]$. Preural centrum 1 with rudimentary neural spine. 'First' ural centrum with rudimentary neural arch. Hypurals 1 and 2 fused to a large 'first' ural centrum. Two long epurals [*]. Anterior series of three long and slender uroneurals. Uroneural 1 reaching preural centrum 2 . With three epaxial fringing fulcra. Two dorsal and two ventral scutes preceeding the caudal fin [*]. Large cycloid scales; vertical rows composed of three scales in dorsal part of flank. below dorsal fin [*]. (Uniquely derived characters among allothrissopid ichthyodectiforms are identified by ["].)

Etymology: Refers to the curious overall similarities of the new genus to both $\uparrow$ Ascalabos $\mathrm{v}$. Münster, 1939b (a basal teleost) and $\uparrow$ Pachythrissops Woodward, 1919 (an ichthyodectiform).

Type species: $\nmid$ Ascalabothrissops voelkli $\mathrm{n}$. sp.

\section{$\dagger$ Ascalabothrissops voelkli $\mathbf{n}$. sp.}

Figs 2-7

Diagnosis: Same as for genus.

Holotype: JM SCH 30a. b. complete specimen preserved in part and counterpart.

Type locality and age: Schamhaupten. near the town of Eichstätt (Fig. 1). Late Jurassic. Kimmeridgian

Etymology: The specific name honors $\mathrm{Mr}$. Giuseppe Völkl who has dedicated a significant part of his life to the preparation of specimens deposited in the Jura Museum. He especially has helped me with the preparation of numerous specimens, always doing his best.

Description: The small fish (Figs $2 \mathrm{~A}, \mathrm{~B}, 3$ ) of about $91 \mathrm{~mm}$ total length and about $80 \mathrm{~mm}$ standard length (SL) has a large head of about $28 \%$ in SL. The pelvic fin originates at the middle of SL. Dorsal and anal fin origins are posteriorly placed. The fish has a predorsal length of about $63 \%$ in SL and a preanal length of about $66 \%$ in SL. The peduncle depth is about half of body depth. The tail is small (about $18 \%$ of SL).

All head bones are severely damaged, with the few exceptions described below. The cranial roof (Fig. 4A, B) has preserved thin, elongate parietal bones [ $=$ the so-called frontal bone in teleosts] whose suture with the postparietal [= parietal] is not observed. The broad supraorbital sensory canal extends posteriorly into the postparietal bone. Anterior to the parietal is an incomplete mesethmoid with an elongate, narrow lateral wing. Ventral to the lateral ethmoid is a piece of the ethmovomerine region; two conical teeth, interpreted as vomerine teeth, are preserved. A ventrolateral, triangular lateral ethmoid is placed just in front of an incomplete anterior sclerotic bone. The elongate, narrow parasphenoid seems to be edentulous and its ascending process small. Part of a chondral bone, here identified as prootic, sutures with the ascending process. Another chondral bone lies dorsal to the prootic; this bone is interpreted as the sphenotic. because of its position.

The circumorbital series is only represented by infraorbital 2 and a piece of infraorbital 3 (Fig. 4A). The infraorbital canal running through infraorbital 2 is very broad. A piece of the anterior sclerotic bone is preserved.

The upper jaw (Fig. 4A, B) is composed of a triangular elongate premaxilla bearing a row of conical teeth along its ventral margin. The maxilla is incomplete and preserved only at its anterior and posterior ends; it is a strong bone bearing a short articular process and a row of conical teeth at its oral margin. The supramaxillae are destroyed. The lower jaws (Fig. 4A, B) are represented mainly by the anterior parts of both dentaries. The lower jaw extends anterior to the premaxilla as it does in $\dagger$ Ascalabos and in $\dagger$ Pachythrissops (Arratia 1997: figs 14A, B, 15, 16, 22A, B). Each dentary has a deep coronoid process and a row of conical teeth at its oral margin. The quadrate-mandibular articulation is placed below the posterior half of the orbit. A slender small gular plate lies between both dentaries.

The pterygoid bones (Fig. 4A, B) are represented by a piece of the metapterygoid, and a damaged entopterygoid. A few conical teeth are found in the area commonly occupied by the entopterygoid and consequently they are interpreted as entopterygoid teeth. Anterior to the entopterygoid is a piece of a thin bone that has preserved four conical teeth and is interpreted as the dermopalatine. The hyomandibula (Fig. 4A) 

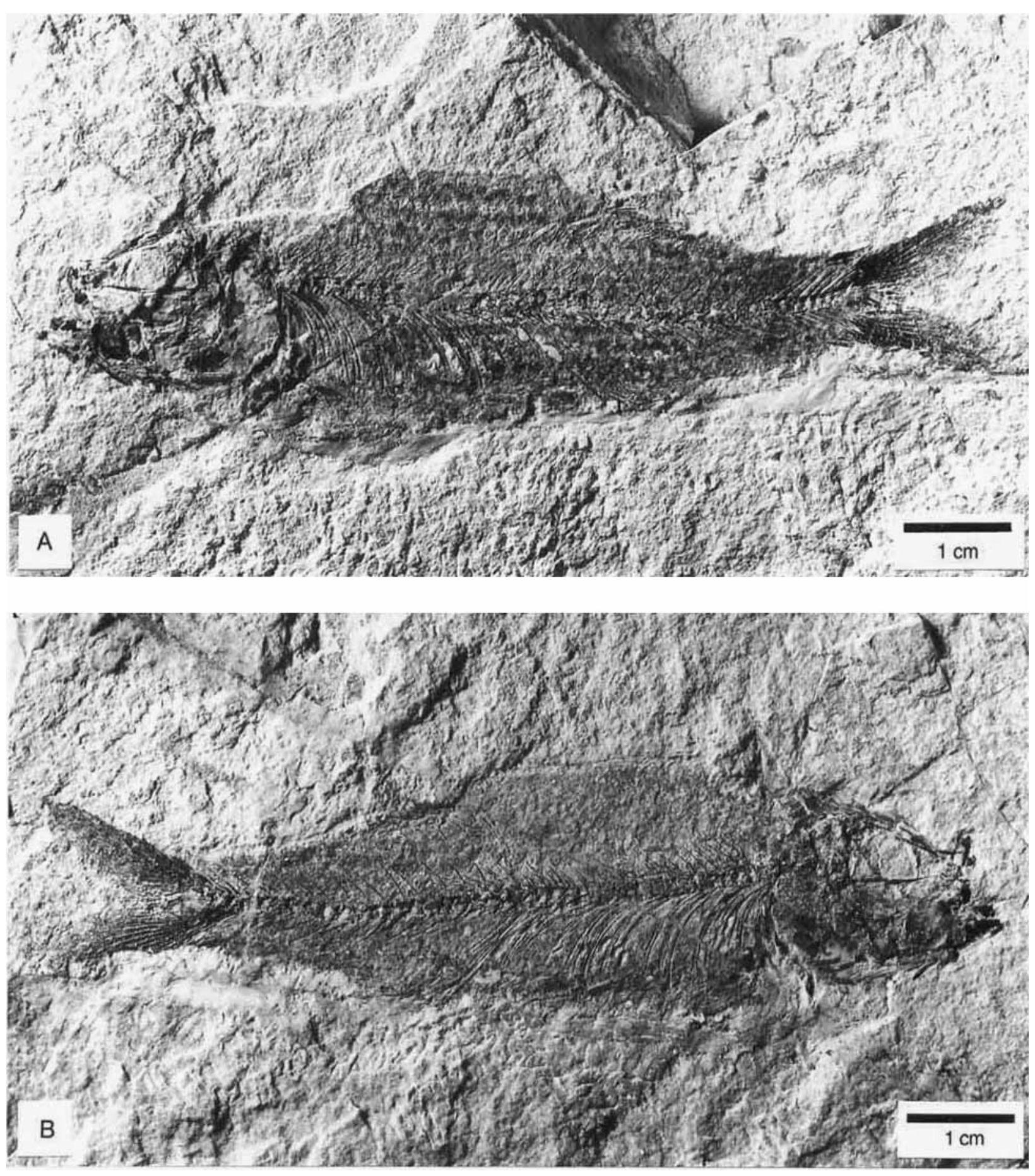

Fig. 2. †Ascalabothrissops voelkli $\mathrm{n}$. gen. and $\mathrm{n}$. sp. from the Kimmeridgian of Schamhaupten, Bavaria. A. Lateral view of holotype JM SCH 30a. B. Lateral view of holotype JM SCH 30b

is a deep, narrow bone with an anterior membranous outgrowth, slightly larger than that in $\dagger A s c a$ labos voithii (Arratia 1997: fig. 18A); the outgrowth is partially covered by part of the metapterygoid. The symplectic is a styliform, long bone.

The preopercle (Fig. 4A) has a curious shape: it is slightly expanded at its ventral $\operatorname{limb}$, and then, it narrows considerably producing an elongate dorsal limb. The preopercular sensory canal is moderately broad, with moderately broad tubules extending close to the ventral and posterior margins of the bone. There are six tubules at the ventral limb. The opercle is deeper than long, its dorsal margin is gently rounded, and the bone is broader at its contact with the subopercle. Five branchiostegal rays are incompletely preserved.

There are 41 vertebrae; about 19 caudals (including preural centrum 1) and 22 abdominals; 


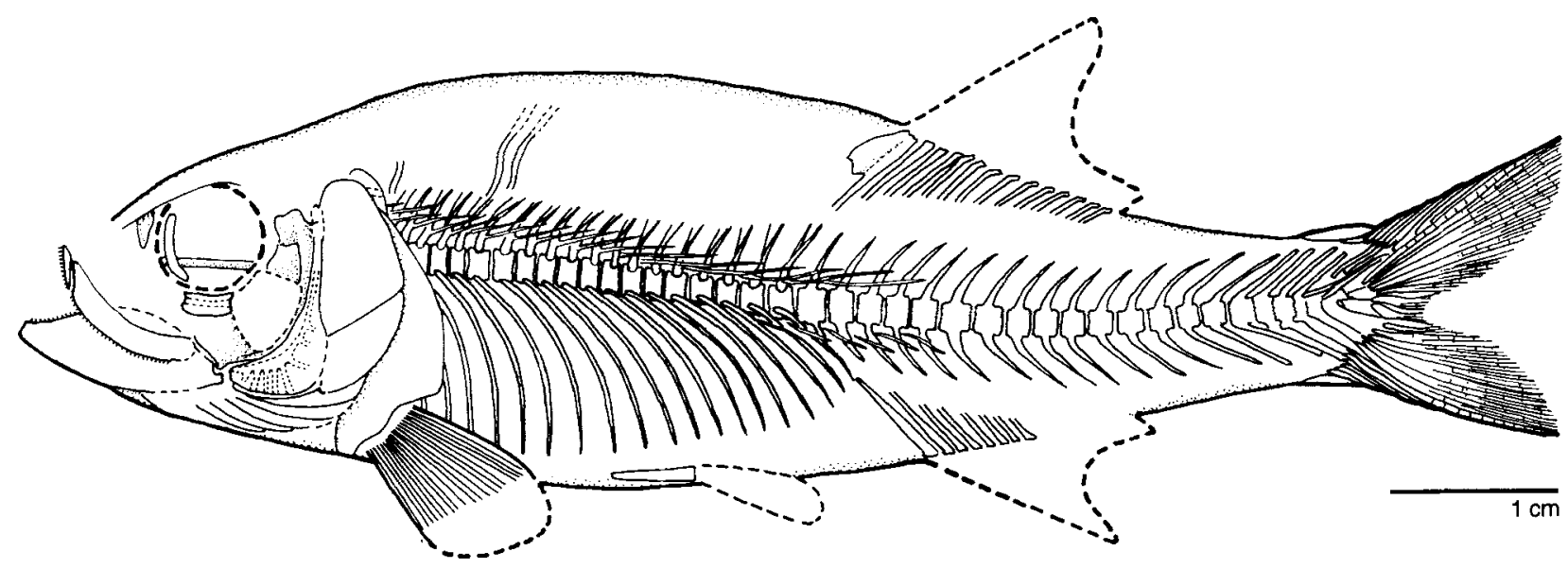

Fig. 3. Ascalubothrissops velkii n. gen. and n. sp. from the Kimmeridgian of Schamhaupten, Bavaria. Restoration in lateral view

the limit between the abdominal and caudal regions of the vertebral column is unclear. The vertebral column is almost straight like in $\dagger$ Pachythrissops (Arratia 1997: fig. 22A. B) and lacks the curious curvature present in $\uparrow$ Ascalabos (Arratia 1997: fig. 15). The surface of the vertebrae (Figs 5,6) is smooth, without any kind of ornamentation. The anterior abdominal vertebrae (Fig. 4A) are slightly squarish in shape and their size increases caudally. Abdominal vertebrae have autogenous neural arches: the left and right halves of each arch are not fused into one spine as in the last abdominal and all caudal vertebrae. The caudal vertebrae (and also the abdominals) bear narrow neural and haemal arches and the spines are short (not reaching the margins of the trunk) and narrow lacking any sort of membranous outgrowths (Fig. 5). The neural and haemal arches of anterior and midcaudal vertebrae sit in the middle of the dorsal and ventral margin of each centrum, respectively. Last caudal vertebrae have both the neural and haemal arches slightly displaced posteriorly and the spines are slightly inclined toward the horizontal. The centra have small anterior and posterior projections, not always very distinct, which look like rudimentary pre- and postzygapophyses.

There are about 20 pairs of long ribs preserved; most of them almost reach the ventral margin of the body, except for the last ones which become shorter. Each rib articulates on a ventrolateral cavity of the centrum.

Only a few. displaced supraneural bones (Fig. 4A) are preserved. They are slender. elongate. and apparently do not extend between the first dorsal pterygiophores like those in other basal teleosts. There are long. fine epincurals (Fig. 4A. 5). However, due to incomplete preser- vation, it is not possible to establish whether the last epineurals are free bones or processes of the neural arches of the abdominal vertebrae. Each epineural is formed by compact bone and remains of cartilage are not observed inside the perichondral ossification. The first ones are thicker than other epineurals and extend almost parallel to the vertebral column. The last epineurals reach the middle of the base of the dorsal fin. Slender, elongate epipleural bones are present below the last abdominal and first caudal centra (Fig. 5). Apparently, they are free, lying laterally to the last ribs and to the haemal arches and short haemal spines of the first caudal vertebrae.

From the pectoral girdle (Fig. 4A) only a piece of the supracleithrum and a long, slightly broad cleithrum are preserved. The supracleithrum carries a section of the lateral line, and because of its position, it is asumed here that the exit of the lateral line was at the dorsal region of the bone. The pectoral fin has approximately 20 rays with long unsegmented bases and finely branched distally.

Both pelvic plates (Fig. 5) are preserved. They are triangular in shape and as broad anteriorly as posteriorly. They retain calcified cartilage in both extremes. Both plates are in close contact medially and not only at their posterior ends as occurs in $\dagger$ Ascalabos (Arratia 1997: fig. 19C). Both pelvic fins overlap each other; therefore, the number of rays is unknown.

The dorsal fin (Fig. 5) is incompletely preserved. Fourteen pterygiophores support the rays. The first pterygiophore has a broad membranous expansion anteriorly and is much more expanded than the first pterygiophore in $\dagger$ Ascalabos (Arratia 1997: fig. 19B). With the exception of the first pterygiophore all others are thin, nar- 

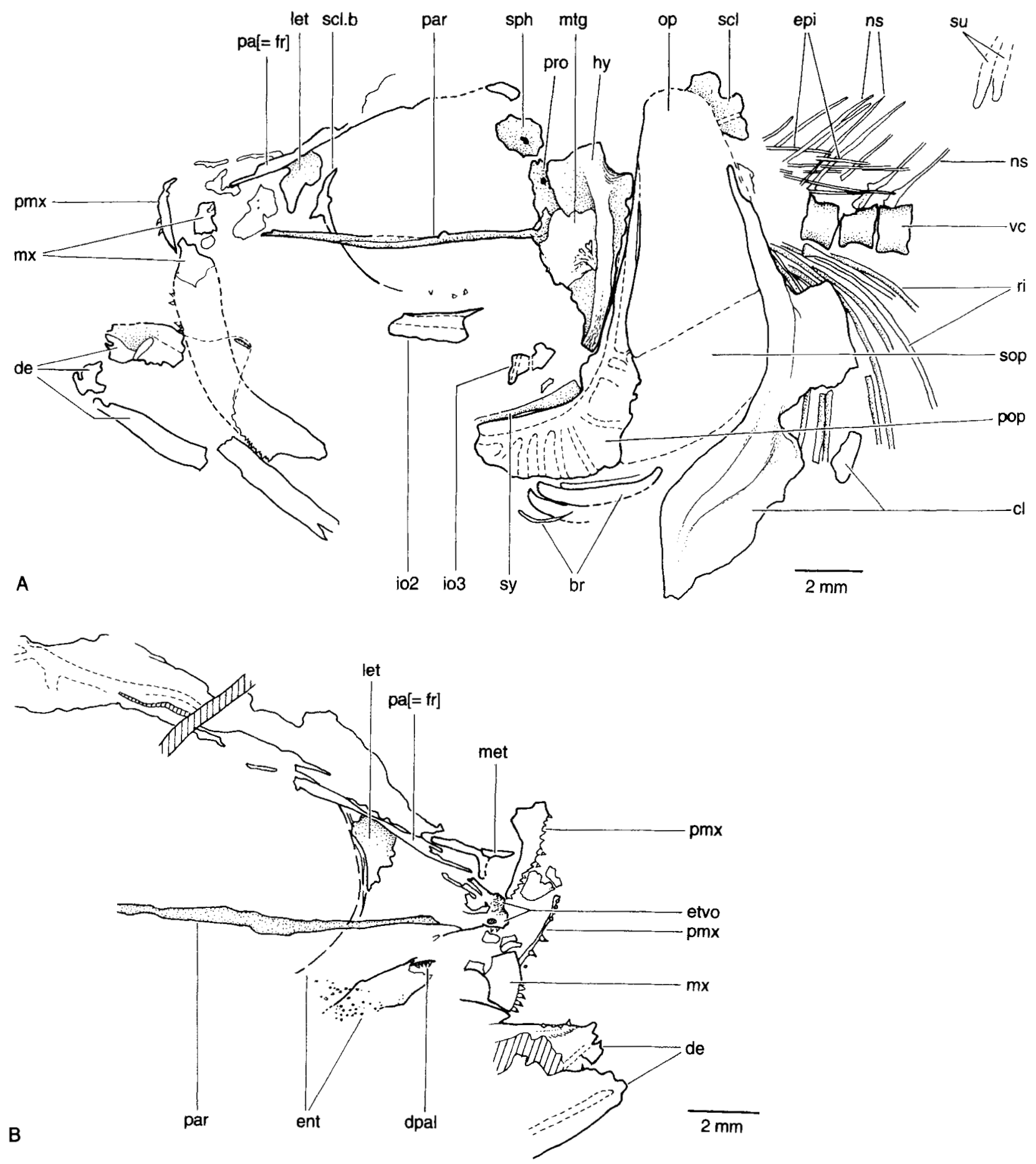

Fig. 4. †Ascalabothrissops voelkli n. gen. and n. sp. from the Kimmeridgian of Schamhaupten, Bavaria. Some head bones in lateral view. A. Holotype JM SCH 30a. B. Holotype JM SCH 30 b.

br, branchiostegal ray; cl, cleithrum; de, dentary; dpal, dermopalatine; ent, entopterygoid; epi, epineural bone; etvo, ethmovomerine region; hy, hyomandibula; io2-3, infraorbital bone 2-3; let, lateral ethmoid; met, mesethmoid; mtg, metapterygoid; mx, maxilla; ns, neural spine; op, opercle; pa[= fr], parietal bone [so-called frontal bone]; par, parasphenoid; pmx, premaxilla: pro, prootic; ri, rib; scl, supracleithrum; scl.b, sclerotic bone; sop, subopercle; sph, sphenotic; su, supraneural bone; sy, symplectic; vc, vertebral centrum;

row elements that are well separated from the distal tips of the neural spines. There are eight anal pterygiophores preserved. The first two are the longest and strongest. The anal rays are considerably damaged so that it is not possible to establish their total number.
Five preural vertebrae support the caudal rays (Fig. 6). The preural centra lack the lateral crest present on the lateral surface of the preural centra in $\dagger$ Ascalabos and in the ichthyodectiforms (Arratia 1991, 1997). The neural spines of preural centra 5-2 are narrow and moderately long 


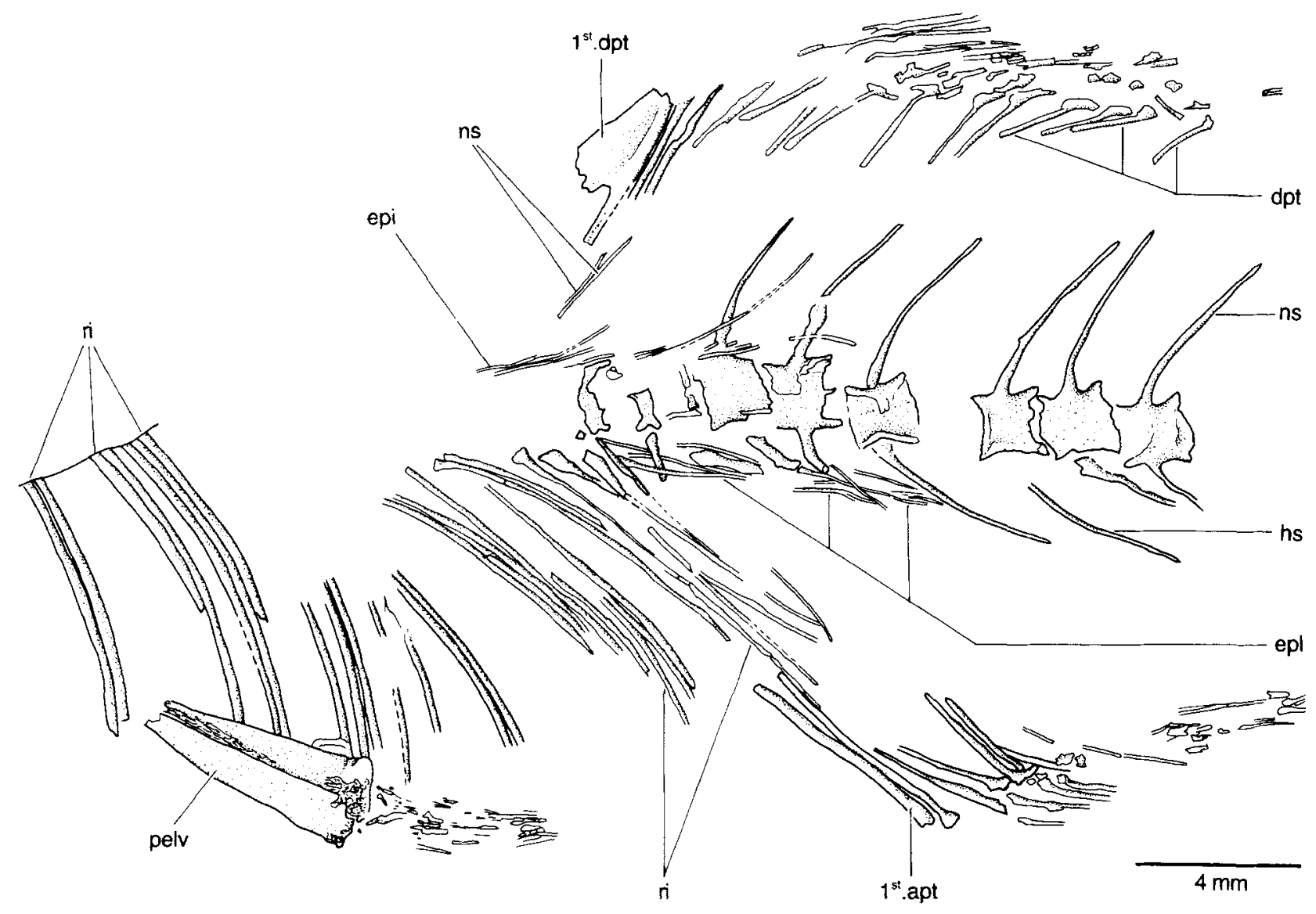

Fig. 5. $\dagger$ Ascalabothrissops voelkli n. gen. and n. sp. from the Kimmeridgian of Schamhaupten, Bavaria. Abdominal and caudal vertebrae and associated elements. pelvic plate. and dorsal and anal fins (JM SCH 30a).

dpt, dorsal pterygiophore: epi. epineural bone: epl. epipleural bone: hs. haemal spinc; ns, neural spine; pelv, pelvic bone; ri,

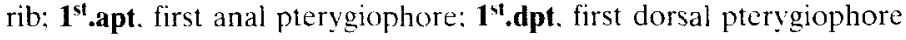

and their inclination toward the horizontal progresses caudally. Preural centrum 1 has a complete neural arch and a rudimentary neural spine. The haemal spine of preural vertebra 5 (and anterior vertebrae) is shorter and narrower than the other preural vertebrae; haemal spines 4-1 are broad elements whose distal tips are covered by the rays.

The 'first' ural centrum (Fig. 6) is considerably large and is fused to the hypurals 1 and 2 . Because of its size and relation to the hypurals it is assumed here that this centrum corresponds to the fusion of ural centra 1 and 2 following the polyural terminology (for details see Schultze \& Arratia 1989 and Arratia \& Schultze 1992). This centrum has an elongate, rudimentary neural arch. The 'second' ural centrum is partially covered by the uroneurals and bases of dorsal hypurals; therefore, its length is unknown.

There are two long. slightly broad epurals (Fig. 6): the epurals and the second uroneural support the epaxial rays or basal fulcra. Five uroneurals are present. The relation of the uroneurals between them, and their shapes and sizes resemble more the condition in the ichthyodectiform $\dagger$ Occithrissops (see below) than in $\dagger$ Ascalabos. The first uroneural reaches preural centrum 2 and uroneurals 2 and 3 reach the 'first' ural centrum. The fifth uroneural is short and slender.

Only five hypurals (Fig. 6) are visible; most dorsal hypurals are covered by the bases of the principal caudal rays. Hypurals 1 and 2 are fused at their bases and both fuse with the 'first' ural centrum. Hypural 2 is as long as hypural 1; apparently, a diastema between hypurals 2 and 3 is missing.

There are seven epaxial rays (Fig. 6) that look like epaxial fulcra, three elongate fringing fulcra (lying against the first principal caudal ray), 10 dorsal and 9 ventral principal caudal rays, and five ventral rays. There are two dorsal scutes; the first one is broad and large and the second is narrow and elongated. The anterior tip of the first scute is bifurcated; it is unclear whether the posterior tip is also bifurcated. There are two ventral scutes; both are slender and have their anterior tips bifurcated. 


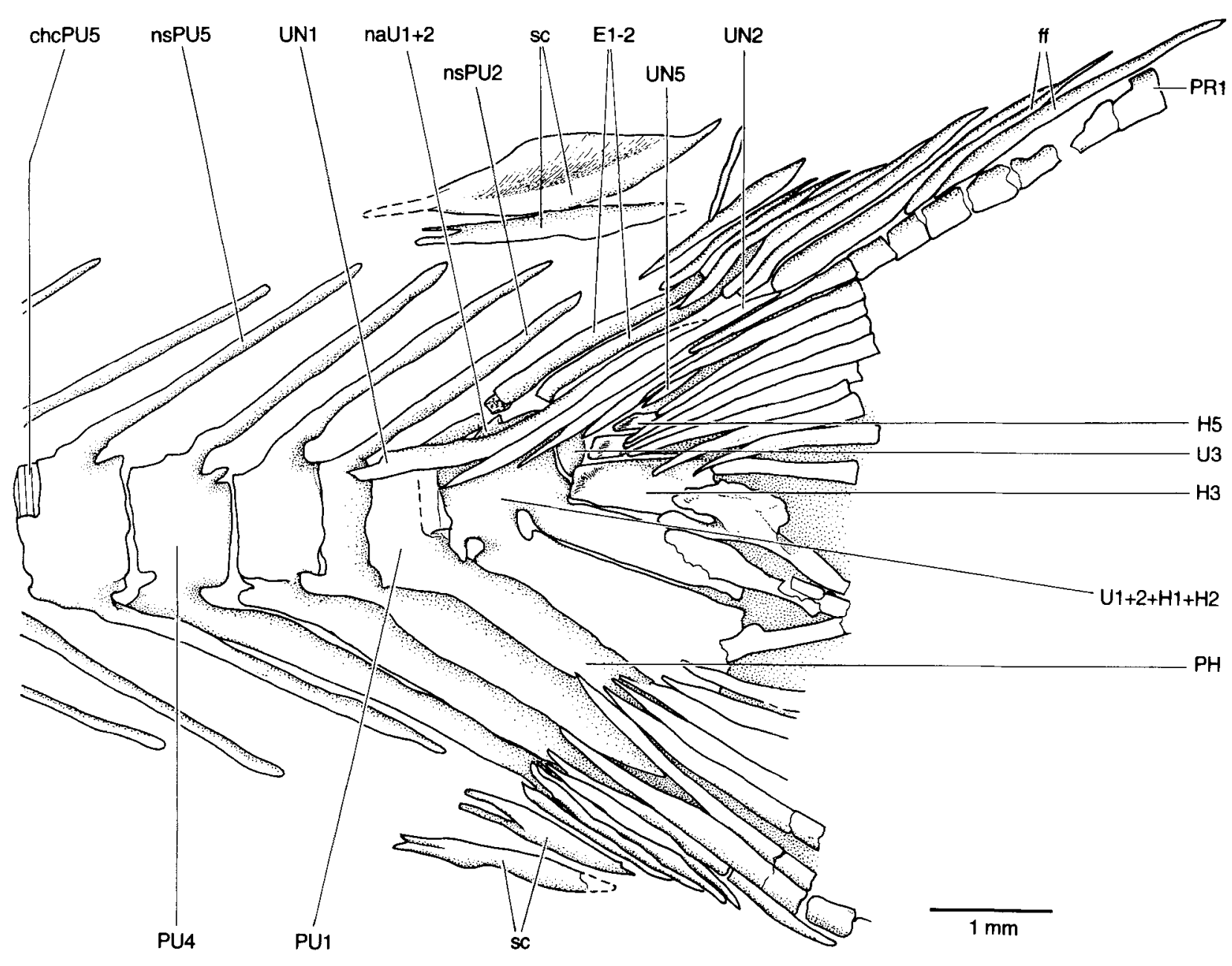

Fig. 6. $\dagger$ Ascalabothrissops voelkli $\mathrm{n}$. gen. and $\mathrm{n}$. sp. from the Kimmeridgian of Schamhaupten, Bavaria. Posterior caudal vertebrae and caudal skeleton (JM SCH 30a).

chePU5, chordacentrum of preural centrum $5 ; \mathbf{E 1 - 2}$, epural 1-2; ff, fringing fulcra; H1-5, hypural 1-5; naU1+2, neural arch of 'first' ural centrum; nsPU2-5, neural spine of preural centrum $2-5 ; \mathbf{P H}$, parhypural; PR1, first principal caudal ray; PU1-4, preural centrum 1-4; sc, scute; U3, ural centrum 3; U1+2+H1+H2, 'first' ural centrum fused with the bases of hypurals 1 and 2; UN1-5, uroneural $1-5$

'Urodermal'(s) (sensu Arratia \& Schultze 1992) are not observed because of poor preservation.

The flexion of the tail begins at the level of the 'first' ural centrum and produces a slight dorsal curvature.

The cycloid scales are large and oval. Scales of the dorsal part of the flank have a few circulii in their anterior field (Fig. 7A); however, scales posterior to the dorsal fin are slightly smaller and have more circulii in the anterior-middle field (Fig. 7B). The preservation of the scales is not good enough to permit a count of scales rows on the whole body.

Comparison and discussion: The first things that call attention to the new fish are the posterior position of the dorsal fin, almost opposite to the anal fin, and the short, compact body with few vertebrae (Figs 2A, B, 3). Thus, my first reaction was to think of a 'hybrid' between $\dagger$ Ascalabos and $\dagger$ Pachythrissops.

$\dagger$ Ascalabothrissops voelkli $\mathrm{n}$. gen. and $\mathrm{n}$. sp. resembles $\nmid$ Ascalabos in several features. For instance: 1) The lower number of vertebrae. Among Jurassic teleosts $\nmid$ Ascalabos is characterized for having few vertebrae, e.g., 34-39 (Arratia 1997), 38-40 (Nybelin 1974), and 43 (Taverne 1975b). $\dagger$ Ascalabothrissops has ca. 41 vertebrae. Such a count is more similar to that of $\dagger$ Ascalabos than to other Late Jurassic teleosts such as the ichthyodectiforms with over 50 vertebrae (Bardack 1965, Patterson \& Rosen 1977), $\dagger$ Leptolepides with 44-50 vertebrae (Nybelin 1974, Taverne 1981, Arratia 1997), †Orthogonikleithrum with 46 or 47 (Arratia 1997), etc. (2) The shape of the caudal vertebrae in both genera is similar (Figs 5, 8A), with slender neural 

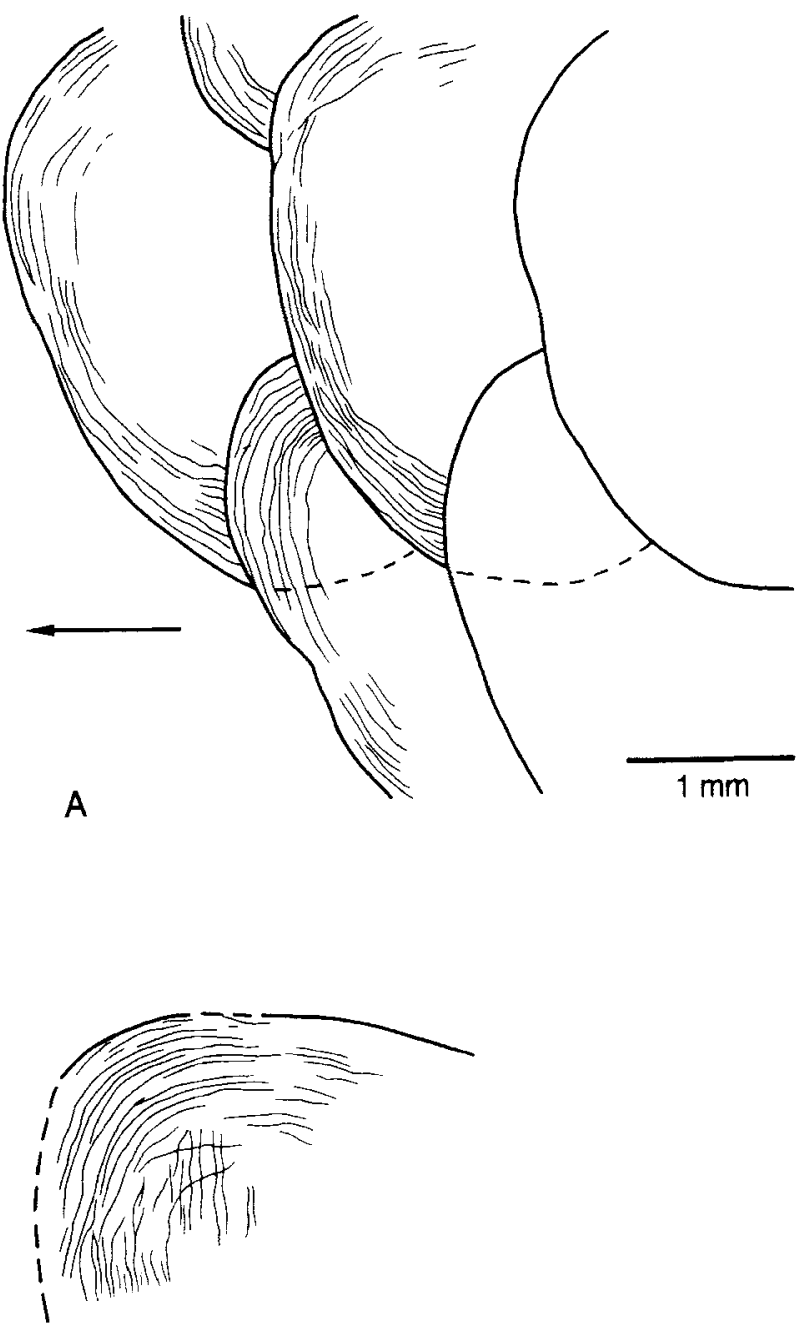

B

Fig. 7. $\nmid$ Ascalabothrissops voelkli $\mathrm{n}$. gen. and $\mathrm{n}$. sp. from the Kimmeridgian of Schamhaupten. Bavaria (JM SCH 30a). A. Scales of the dorsal part of flank. below dorsal fin base. B. Scales of the ventral part of the caudal peduncle. Arrow points anteriorly

and haemal arches and slender neural and haemal spines. However, they differ in that the new fish does not have the longitudinal lateral crest present in the caudal vertebral centra of $\dagger$ Ascalabos. (3) One character of the genus $\dagger$ Ascalabos is the presence of broad sensory canals bearing short tubules ending in a sharp point. The preopercle is characterized by few, short and sharp sensory tubules (Arratia 1997: figs 16, 17A, C; Fig. 9A). In $\dagger$ Ascalabothrissops the sensory canals are broad, but the sensory tubules do not end sharply. In addition, the sensory tubules reach the ventroposterior margin of the preopercle in the new fish (see Fig. 4A). (4) Both genera share the primitive number of principal caudal rays (19), and (5) probably the presence of epaxial basal fulcra. (6) In $\dagger$ Ascalabos, as in the new fish, there are two dorsal scutes preceding the caudal fin. However, their shapes are different.

Despite the general resemblance between the caudal skeleton of $\dagger$ Ascalabos and the new fish (compare Fig. 6 and fig. 20 in Arratia 1997), there are other significant morphological differences such as: 1) A series of epipleural bones lying ventral to the last abdominal and first caudal centra is present in $†$ Ascalabothrissops, whereas few epipleurals placed below the first caudal centra are found in $\dagger$ Ascalabos. (2) A very short neural spine on preural centrum 1 is present in $\dagger$ Ascalabothrissops; in contrast the spine is longer in $\nmid$ Ascalabos. (3) A rudimentary neural arch is present over the 'first' ural centrum in $\dagger$ Ascalabothrissops, whereas a broad arch with a short spine is present in $\dagger$ Ascalabos. (4) Three short epurals are present in $\dagger$ Ascalabos; two long epurals are in $\dagger$ Ascalabothrissops. (5) There are three epaxial fringing fulcra preceding the first principal caudal ray in $\dagger$ Ascalabothrissops, whereas they are absent in $\dagger$ Ascalabos. (6) Two ventral scutes are present in $\dagger$ Ascalabothrissops, only one in $\dagger$ Ascalabos.

On the other hand, the new fish resembles the ichthyodectiforms in the following features: 1) Posterior position of dorsal and anal fins; dorsal fin almost completely opposite to anal fin. Despite such overall similarities, the new fish differs from the Jurassic ichthyodectiforms Occithrissops, Allothrissops, and Thrissops in that the dorsal fin is short and opposed to a long anal fin. That is not the pattern found in $\uparrow$ Ascalabothrissops (Figs 2A, B, 3, 5) with a short anal fin. However, the position of both dorsal and anal fins is shared by $\dagger$ Ascalabothrissops and the ichthyodectiform $†$ Pachythrissops. (2) The ichthyodectiforms commonly have more than 50 vertebrae; however, $\dagger$ Pachythrissops is an exception with 46 or 47 . Still $\dagger$ Ascalabothrissops has fewer vertebrae (ca. 41) than $\nmid$ Pachythrissops. (3) The ichthyodectiforms are characterized by the presence of five to seven uroneurals (see below Fig. 10), the first three or four extending anteroventrally to cover the entire lateral surface of the first, second, or third preural centra (Patterson \& Rosen 1977). The anterior series of uroneurals in the new fish resembles the pattern found in the oldest ichthyodectiform Occithrissops and in the Late Jurassic $\nmid$ Pachythrissops propterus (compare Figs 6 and 10A, B). $\dagger$ Ascalabothrissops n. gen. has two long epurals. Ichthyodectiforms have two to three epurals; however, $\dagger$ Pachythrissops propterus shows intraspecific variation and may present two or three short epurals (Arratia 1997: figs 24, 25). $†$ Ascalabothrissops 
n. gen. differs from the ichthyodectiform caudal skeleton in the presence of a rudimentary neural spine on preural centrum 1 , in the presence of a rudimentary neural arch over the long 'first' ural centrum, the presence of two epurals, the fusion of hypurals 1 and 2 with the 'first' ural centrum, and others (for more differences compare Figs 6 and $10 \mathrm{~A}-\mathrm{D}$ ).

In conclusion, the fish described above is proposed as a new genus and species, $\nmid$ Ascalabothrissops voelkli, because of its autapomorphic characters and its combination of morphological features. Such a combination is unique among Jurassic teleosts. The position of $\dagger$ Ascalabothrissops as the sister-group of $\dagger$ Pachythrissops is explained in the section dealing with phylogenetic analyses (see below).

Division Teleostei sensu Arratia, 1999

Order $\nmid$ Ichthyodectiformes Bardack \& Sprinkle, 1969

Family $\nmid$ Allothrissopidae Patterson \& Rosen, 1977 Genus †Allothrissops Nybelin, 1964

Ty pe species: †Allothrissops mesogaster (Agassiz 1833-44) from the Upper Jurassic, Tithonian, Malm Z2 of Bavaria, Germany.

\section{Allothrissops sp.}

Figs 8, 9, 10C

Material examined: MB. f.7286, a very well preserved caudal skeleton and fin (Fig. 8).

Locality and age: Schamhaupten, near the town of Eichstätt (Fig. 1). Late Jurassic, Kimmeridgian.

Description: Each of the last caudal vertebrae (Figs 8, 9) has a strongly ossified autocentrum ornamented with numerous deep grooves and crests. Both neural and haemal arches are autogenous, with both the neural and haemal spines long and inclined toward the horizontal.

There are five vertebrae supporting the caudal fin rays. The neural spine of preural vertebra 2 is slightly expanded distally and reach the dorsal margin of the body. The neural spine of preural centrum 1 is short and also inclined toward the horizontal. The 'first' ural centrum bears an elongate neural arch, and there is no evidence of neural spine.

The haemal arches of preural vertebrae 4-1 are broad, large, and extend slightly anterior to the anterior margin of each preural centrum. The haemal spine of vertebra 4 and most anterior caudal vertebrae lack anterior and posterior membranous outgrowths and are narrow. The haemal spines of preural vertebrae 3 and 2 are expanded because of the presence of membranous outgrowths which are placed anterior and posterior to the heavily ossified chondral region of the spine. The haemal arch of preural centrum 1 is even larger than the anteriormost arches; it has a very well ossified parhypural, which apparently is slightly expanded distally. A hypurapophysis is absent.

The 'first' ural centrum is long and ornamented similarly to the preural centra. Its posterior part articulates with the 'second' ural centrum and partially with hypural 3 . The 'second' independent ural centrum or ural centrum 3 , is very small, slightly triangular, and bears hypural 3 . Because uroneural 5 and the well developed bases of the dorsal hypurals cover the region, it is impossible to check whether another additional ural centrum is present or not.

Three epurals are present. The first one is long and the other two are slightly narrower and shorter than epural 1 . The three produce a series of decreasing length.

Five uroneurals are preserved. The first four uroneurals cover almost the entire lateral surface of preural centra 3-1, which is an ichthyodectiform character. Uroneural 4 is also as long as uroneural 3 and reaches preural centrum 1 . Because of the relation between structures and comparison with the caudal skeleton of $\dagger$ Allothrissops mesogaster, it is likely that a sixth uroneural was present. Uroneural 1 is slightly expanded anteriorly, lying on the lateroventral surface of preural centrum 3. Caudally, it ends just posterior to the neural arch of the 'first' ural centrum. Uroneural 2 is slightly expanded anteriorly, but not as broad as uroneural 1; its posterior part is elongated, but does not reach the distal ends of uroneurals 3 and 4 . Uroneurals 3 and 4 are also slightly expanded anteriorly, but their posterior parts are expanded and consequently broader than other uroneurals. Both uroneurals extend long below the bases of the epaxial procurrent rays.

Five hypurals and the bases of three more are observed. Therefore, the fish has at least eight hypurals. Hypural 1 articulates ventrolaterally with the 'first' ural centrum; the bone is a massive, strongly ossified element with a broadly expanded proximal region; ventrolaterally, it bears a prominent, thick crest and distally the hypural is so expanded that it supports the bases of five principal caudal rays. Hypural 2 is narrower and smaller than hypural 1 , and unlike other ichthyo- 


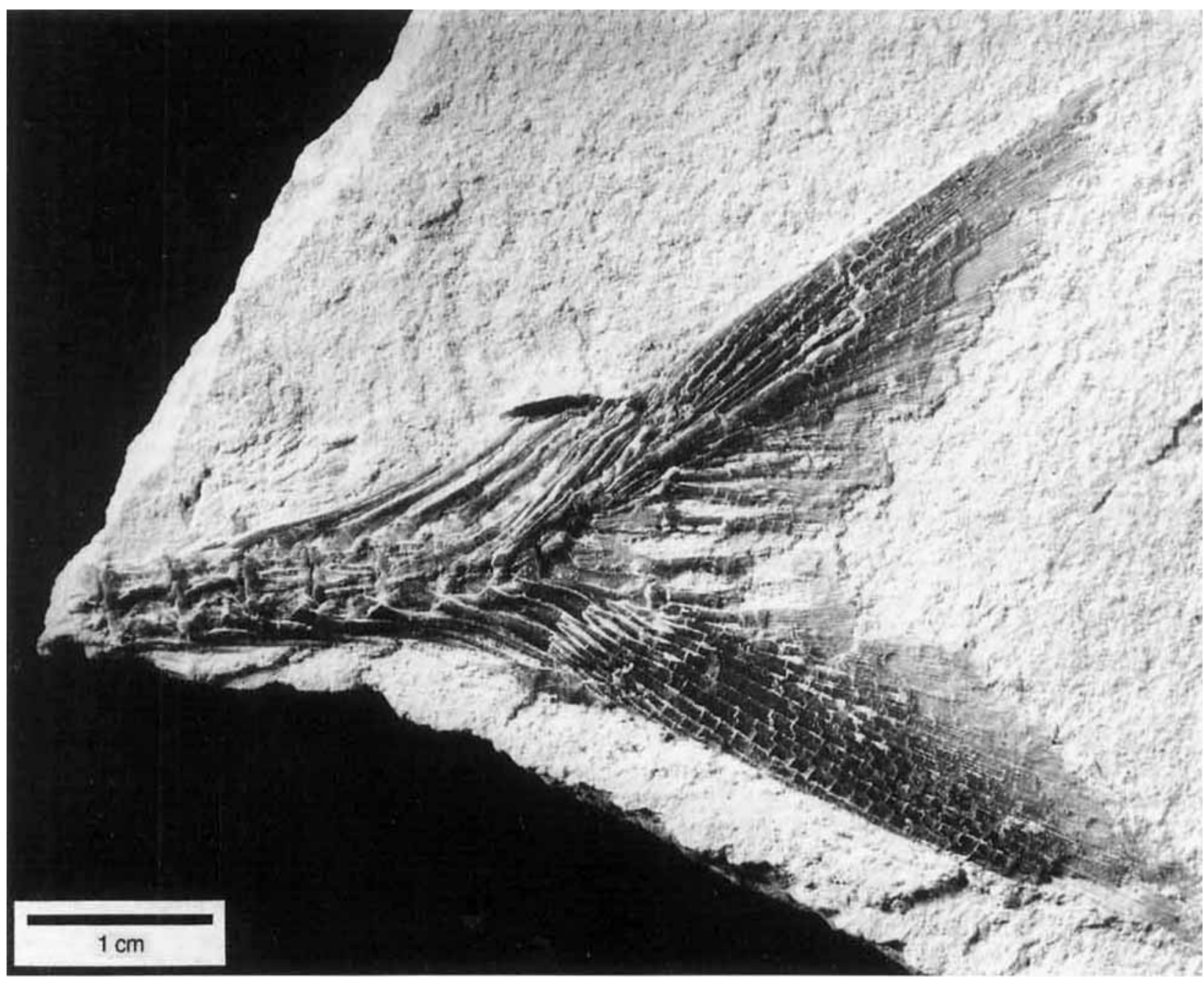

Fig. 8. †Allothrissops sp. (MB. f.7286) from the Kimmeridgian of Schamhaupten. Bavaria. Latcral view of caudal skeleton and caudal fin

dectiforms, is fused to the posterior half of the 'first' ural centrum. An elongate space is left between both hypurals 1 and 2 , and there is a broad diastema between hypurals 2 and 3 . Hypural 3 has a well ossified. laterally expanded base like hypural 4 . The bases of hypurals $5-7$ are preserved only: hypural 8 is partially preserved. The dorsal series of hypurals is almost entirely covered by the bases of the principal rays $1-10$.

'Urodermals' sensu Arratia \& Schultze (1992) are not preserved.

There are seven paired structures which resemble the basal epaxial fulcra in other fishes. four segmented procurrent epaxial rays. 10 dorsal and 10 ventral principal rays, at least two segmented procurrent ventral rays, and four unsegmented rays. The segmentation of the first principal ray is interesting because the long unsegmented base is followed by a series of articulated pieces that have a curious shape and pro- duce the Z- or step-like segmentation characteristic of primitive teleosts. Principal caudal rays $8-10$ have shorter bases than rays $1-7$; the bases of principal rays 8 and 9 bear dorsal, sharp processes like those described by Arratia $(1991,1997)$ in other primitive teleosts. Principal rays 10 and 11 have expanded bases which are finely ossified and cover hypural 3 and part of the hypural diastema and hypural 2, respectively; both rays are the shortest among the principal rays. The total number of 20 principal rays is higher than that in other ichthyodectiforms with 19 rays (e.g., see Patterson \& Rosen 1977, Schaeffer \& Patterson 1984, Arratia 1991, 1997). Twenty principal rays are found in other primitive teleosts (see Schultze \& Arratia 1989, Arratia 1991, 1997).

Dorsal and ventral scutes (Fig. 9) precede the caudal fin. The dorsal scute, moderately narrow and well ossified, reaches anteriorly the neural spine of preural vertebra 4 . The ventral scute, 


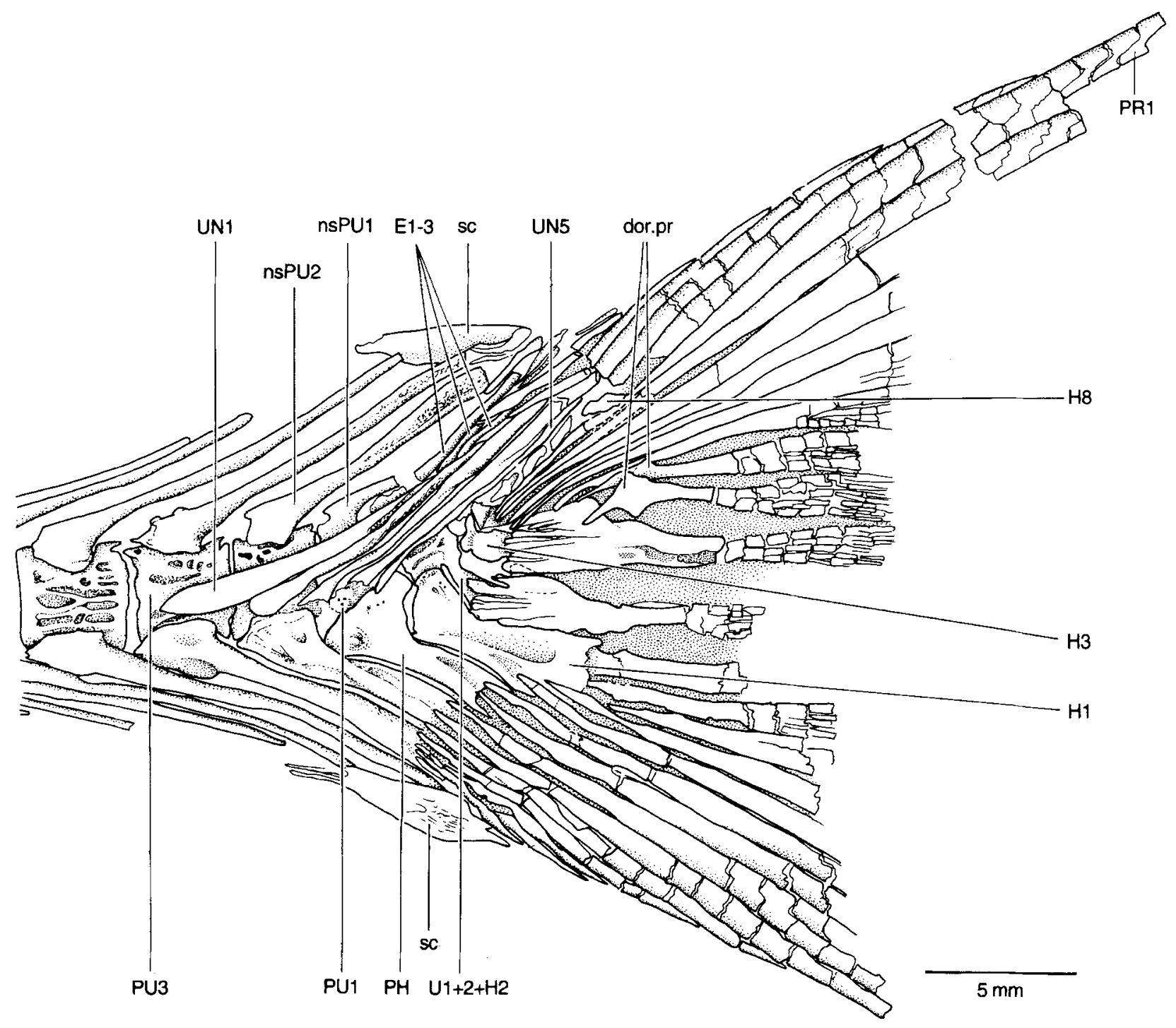

Fig. 9. $\nmid$ Allothrissops sp. (MB. f.7286) from the Kimmeridgian of Schamhaupten, Bavaria. Lateral view of caudal skeleton and caudal fin.

dor.pr, dorsal process; E1-3, epural 1-3; H1-8, hypural 1-8; naU1+2, neural arch of 'first' ural centrum; nsPU1-2, neural spine of preural centrum 1-2; PH, parhypural; PU1-3, preural centrum 1-3; sc, scute; UN1-5, uroneural 1-5; U1+2+H2, 'first' ural centrum fused with the base of hypural 2

also moderately narrow and well ossified, extends until the haemal spine of preural vertebra 6. Two elongate, small structures that look like scutes are posterior to the large ventral scute.

The dorsal flexion of the last preural centra and the ural centra is slight abrupt at the level of preural centrum 1 and caudally.

Comparison and discussion: The caudal vertebrae and the caudal skeleton illustrated in Figures 9 and 10C resemble those of the order Ichthyodectiformes in that the first three or four uroneurals extend anteroventrally to cover the entire lateral surface of the first, second, or third preural centra (Patterson \& Rosen 1977). Among ichthyodectiforms, the caudal skeleton of $\dagger$ Allothrissops sp. is more similar to that of $\dagger$ Allothrissops mesogaster than to those of other Jurassic ichthyodectiforms (compare Figs 9, 10C, $\mathrm{D}$ with $10 \mathrm{~A}, \mathrm{~B}$ ). For instance, the ornamentation of the lateral surfaces of the centra and the shape and angle of the neural and haemal arches and spines resemble the condition in $\dagger A$. mesogaster. $\dagger$ Allothrissops sp. differs from $\dagger A$. mesogaster and other ichthyodectiforms in the fusion of hypural 2 with the 'first' ural centrum and in that the older form from Schamhaupten has the primitive number of principal rays $(10+10)$. whereas $\nmid A$. mesogaster has $10+9$ as in most ichthyodectiforms. As an exception the late Bathonian-Callovian Occithrissops wilsoni has even less $(9+9)$ (Schaeffer \& Patterson 1984: 48). 
$\dagger$ Allothrissops sp. differs from $\uparrow$ Occithrissops in the aspect of the vertebral centra (Fig. 10A. C) and the size and shape of epurals, uroneurals 4 and 5, and in the general proportions of the bones. $\dagger$ Occithrissops has a poorer ornamentation and a thinner autocentrum than $\dagger$ Allothrissops $\mathrm{sp}$.

Vertebrae and caudal skeleton of $\dagger$ Thrissops (e.g., Patterson \& Rosen 1977: figs 13. 14) are in general similar to those of $\dagger$ Allothrissops sp.. but the two genera differ in the fusion of hypural 2 with the 'first' ural centrum and the high number of principal rays of $\uparrow$ Allothrissops $\mathrm{sp}$.

Principal rays 8 and 9 have dorsal processes at their bases in $\uparrow$ Allothrissops and $\uparrow$ Thrissops, but

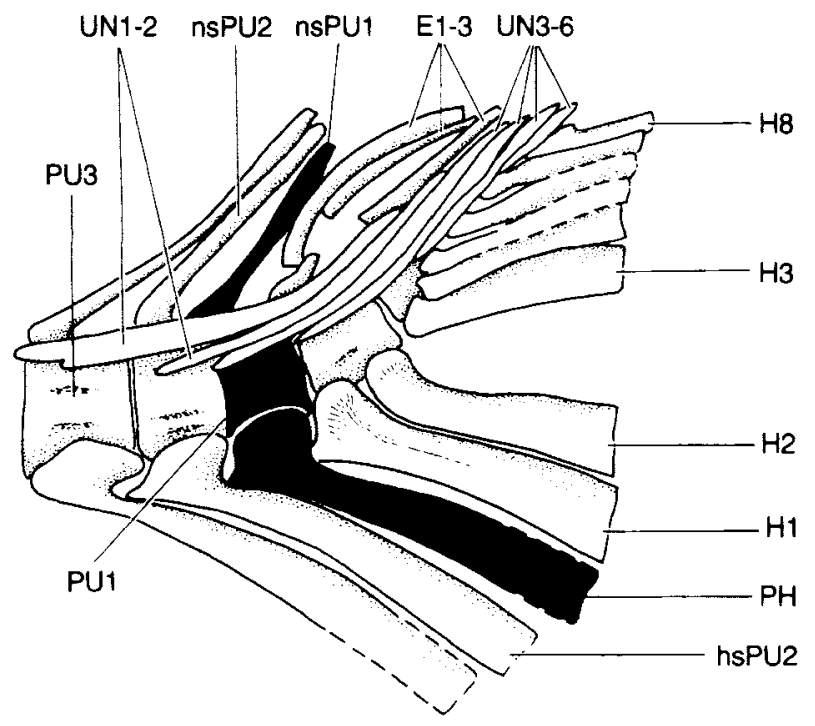

A

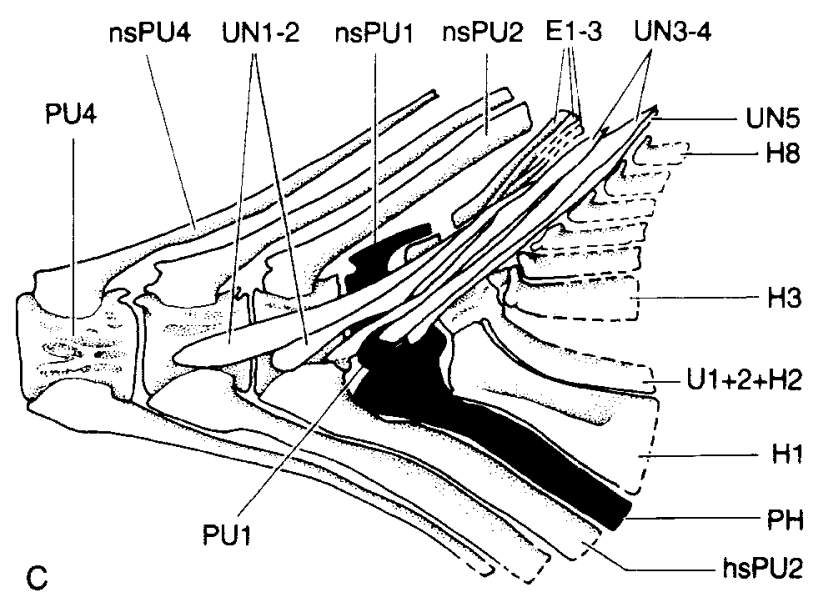

the condition is unclear in fOccithrissops. The presence of these processes is plesiomorphic for basal teleosts and ichthyodectiforms (Arratia 1997, 1999). The bases of the innermost principal rays $(10-11)$ is broadly expanded covering most of the lateral surfaces of hypurals 2 and 3 in $\dagger A l$ lothrissops sp. However, the bases are not as much expanded as in $\dagger$ Occithrissops and $†$ Thrissops.

The fusion between hypural 2 and 'first' ural centrum is unusual among ichthyodectiforms and other teleosts. Similar fusion has been reported from the basal teleost $\nmid$ Protoclupea from the Oxfordian of Chile and from clupeomorphs. Fusion of hypurals with ural centra has been observed
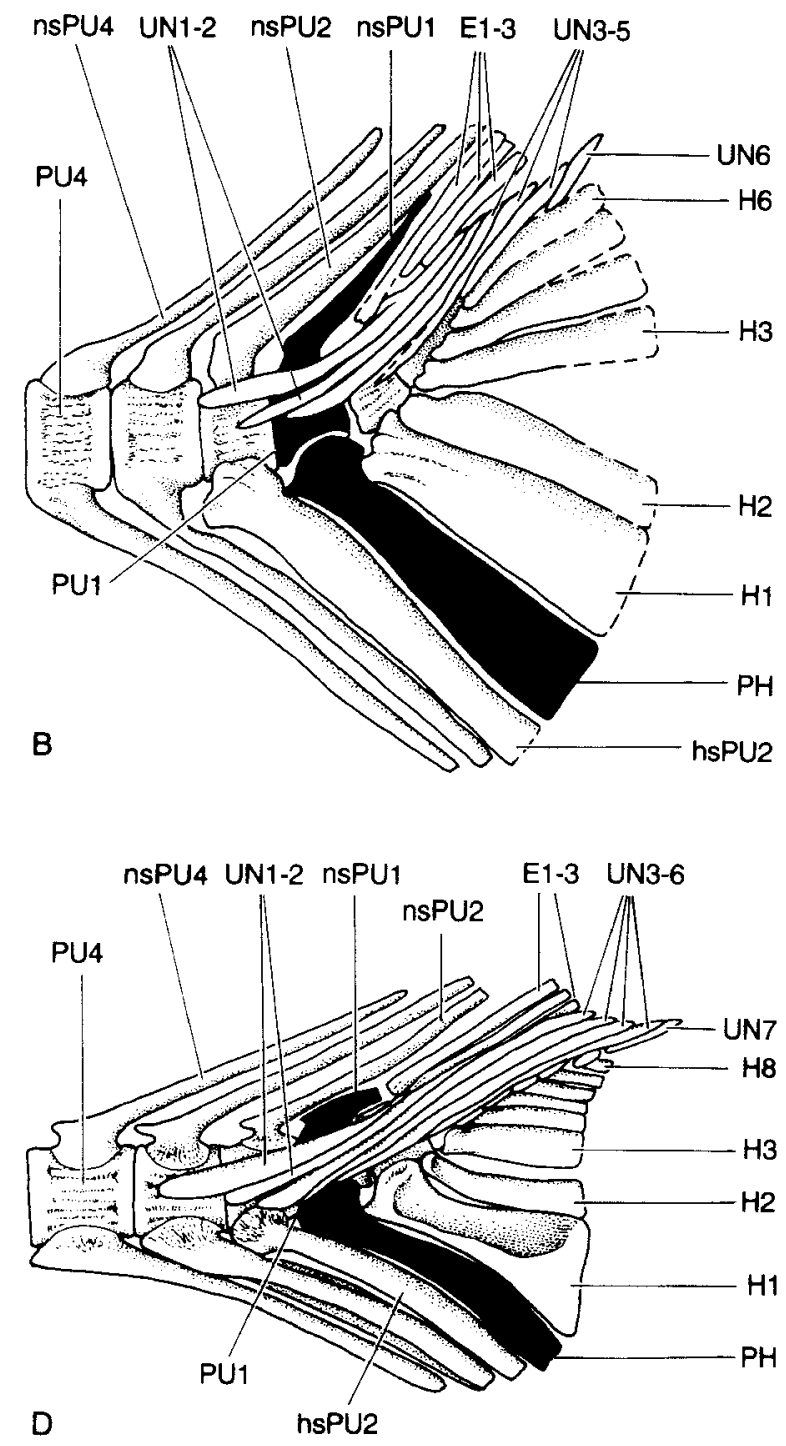

Fig. 10. Restorations of caudal skeleton of certain Jurassic ichthyodectiforms. A. †Occithrissops willsoni from the BathonianCallovian of Hulett. Wyoming. western United States (modified from Schaefer \& Patterson 1984). B. †Pachythrissops propterus from the Tithonian. Malm Z2 of Bavaria. C. $\uparrow$ Allothrissops sp. from the Kimmeridgian of Schamhaupten. D. †Allothrissops mesogaster from the Tithonian. Malm Z2 of Kelheim. Bavaria.

E1-3. epural 1-3: H1-8. hypural 1-8: hsPU2. haemal spine of preural centrum 2; nsPU1-4, neural spine of preural centrum 1-4: PH. parhypural: PU1-4. preural centrum 1-4: U1+2+H2. 'first' ural centrum fused with hypural 2; UN1-7, uroneural $1-7$ 
in late ontogeny of several fossil teleosts. The fusion of hypurals 1 and 2 with the 'first' ural centrum is the primitive condition at the level of $\dagger$ Leptolepis coryphaenoides and more advanced teleosts (Arratia 1996, 1997, 1999). The fusion of only one hypural and the 'first' ural centrum is considered an apomorphic character state. Thus, this specimen is significant because it calls for the need of recovering more specimens of $\dagger$ Allothrissops from this locality.

Division Teleostei sensu Arratia, 1999

Supercohort Elopomorpha sensu Arratia, 1997

Order Elopiformes Greenwood et al., 1966 Genus $\dagger$ Anaethalion White, 1938

Type species: †Anaethalion angustus (v. Münster, 1842) from the Upper Jurassic, Tithonian, Malm Z2 of Bavaria, Germany.

\section{$\dagger$ Anaethalion zapporum n. sp.}

Figs $11-15$

Diagnosis (based on a combination of features): Elongate elopomorph with origin of dorsal fin placed posterior to that of pelvic fin. Antorbital with a long, sharp anteroventral process [*]. Mandibular-quadrate articulation below posterior half of orbit. Maxilla moderately long, almost reaching anterior part of quadrate. Elongate and narrow supramaxillae 1 and 2. Triangu- lar-shaped preopercle, heavily ossified, and with slightly crenulated posterior margin [*]. With 47 vertebrae [*]. Moderately long neural and haemal spines. (Unique characters among $\dagger$ Anaethalion are identified by [*].)

Holotype: JM SCH 85, complete specimen, well preserved (Fig. 11). This is the most informative specimen of $\dagger$ Anaethalion that I have ever examined.

Type locality and age: Schamhaupten, near the town of Eichstätt (Fig. 1). Late Jurassic, Kimmeridgian.

Etymology: The specific name is dedicated to Mr. Manfred Zapp and Mrs. Auguste Zapp (Erlangen, Germany) for their enthusiam collecting and preparing fossils from Schamhaupten and for the gift of some valuable specimens to the Jura Museum.

Description: Slender elopomorph (Figs 11, 12) reaching about $18 \mathrm{~cm}$ total length and $14.4 \mathrm{~cm}$ standard length (SL). The head is large, about $27 \%$ of SL. The origin of the dorsal fin is posterior to that of the pelvic fin. Dorsal fin origin about $56 \%$ of SL and pelvic fin origin about $51 \%$ of SL. Preanal length $71 \%$ of SL. The maximum depth of the body is about $21 \%$ of SL.

The cranial roof (Figs 13,14) has preserved parts of the broad parietal bone and pterotic. The bones are heavily ossified and apparently

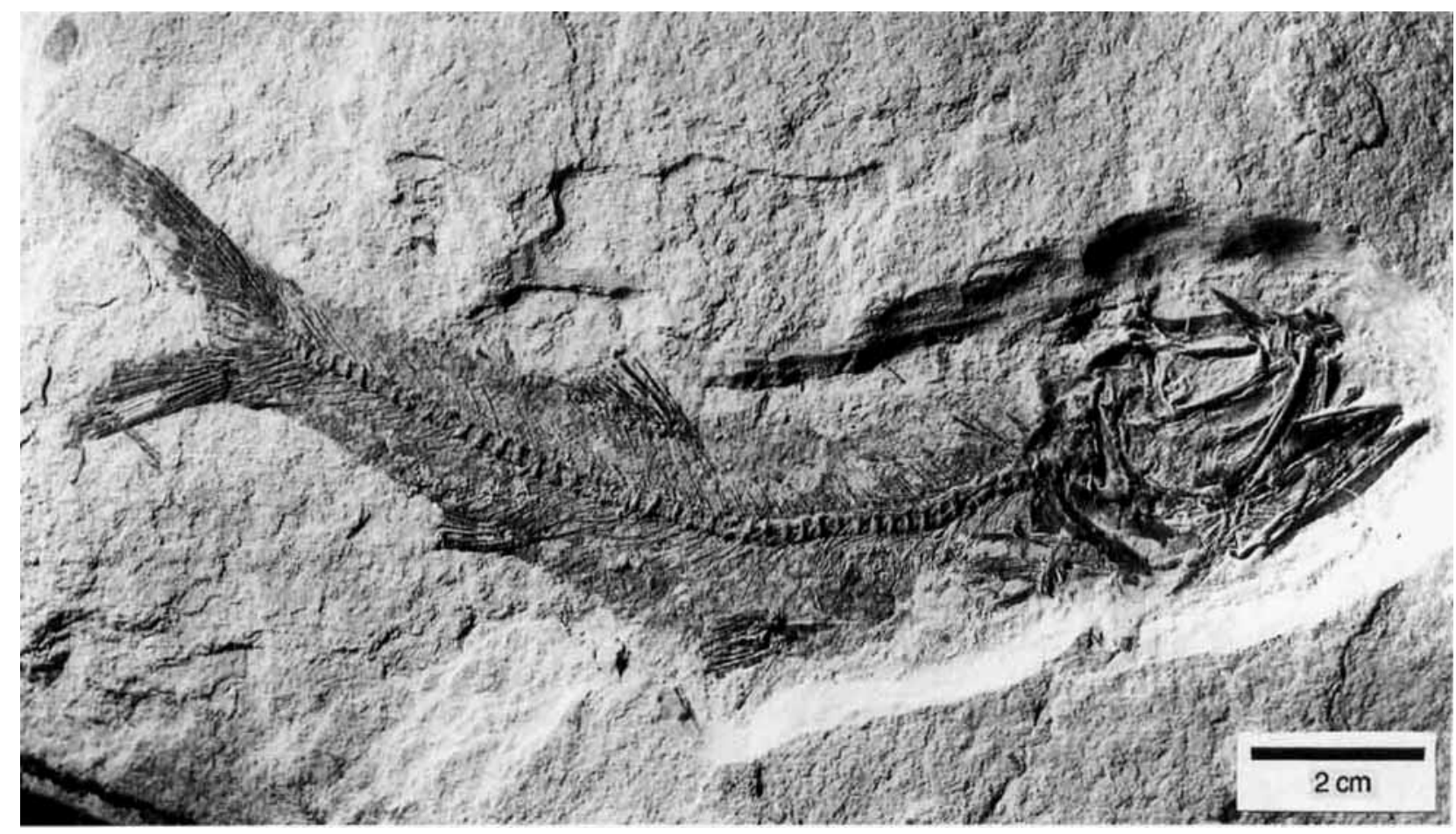

Fig. 11. †Anaethalion zapporum n. sp. from the Kimmeridgian of Schamhaupten, Bavaria. Lateral view (JM SCHA 85) 


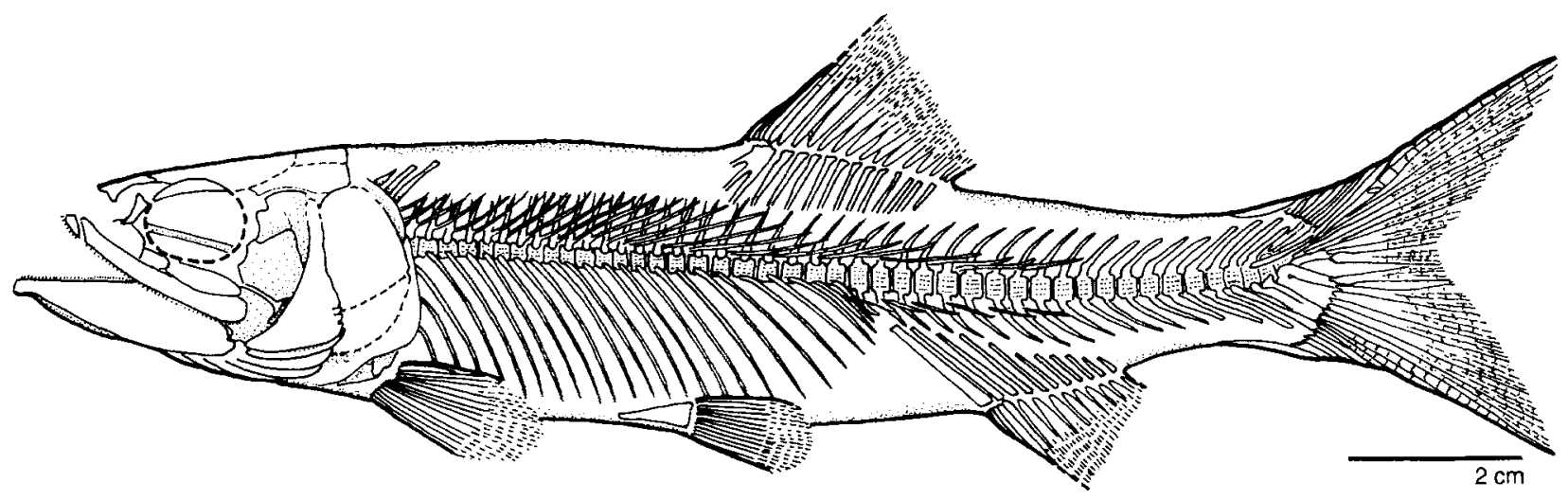

Fig. 12. †Anaethalion zapporum n. sp. from the Kimmeridgian of Schamhaupten. Bavaria. Restoration in lateral view, reversed to the left

the sensory canals run deep because there is no trace of most sensory canals. The broad mesethmoid (Fig. 14) is well ossified: it is slightly arrowlike anteriorly, with well developed lateral processes. The posterior processes are covered by other bones. Like in $\dagger$ Elopsomolos sp. 3 (Arratia 1997: fig. 33A), the pathway of the ethmoidal commissure is accompanied by a few small pores in the bony tube enclosing it. A chondral element lies anterior to the broken parietal bone in between displaced bones; this bone is interpreted here as the lateral ethmoid. The lateral side of the pterotic (Fig. 14) is preserved, as well as a portion of the autosphenotic and prootic. although the dorsal part is partially destroyed. An unknown foramen is observed on the lateral side of the pterotic above the articular facet for the hyomandibula. In addition. the pterosphenoid is preserved. A small orbitosphenoid is anteriorly placed. Another median bone, the basisphenoid, lies above the parasphenoid. The base of the braincase has preserved the posterior process of vomer and part of the parasphenoid. Numerous, small conical teeth are positioned on the ventral face of the parasphenoid, in front of the ascending process. The extension of the parasphenoid toothplate is unknown, because the bone is covered laterally by the metapterygoid.

The circumorbital ring is incompletely preserved. The orbital bones include the two displaced supraorbitals, antorbital, a piece of infraorbital (probably infraorbital 1), and remains of the posterior sclerotic bone (Fig. 14). The supraorbital is an elongate, heavily ossified bone. The antorbital is well ossified; its shape reminds of the bone in $\dagger$ Anaethalion angustissimus, $\uparrow$ Elopsomolos sp. 1, †Elopsomolos sp. 3, and Recent Megalops. However, it has an anteroventral projection larger than that in the above mentioned fishes. The antorbital bears the anterior portion of the infraorbital sensory canal.

The upper jaw is formed by the premaxilla, maxilla, and supramaxillae (Fig. 14). One premaxilla is partially covered by one of the displaced supraorbital bones and the other is represented only by part of its oral margin. The premaxilla is slightly triangular with its oral margin covered by several rows of small conical teeth that resemble villiform teeth. The maxilla is long, reaching the anterior border of the quadrate: its massive articular process is partially covered by the premaxilla. The whole ventral margin (with the exception of the articular process) is covered by numerous small conical teeth. Both supramaxillae are partially preserved. Still it is possible to suggest that they are elongated, narrow bones covering more than half of the dorsal margin of the maxilla, like the condition found in $†$ Anaethalion angustissimus (Arratia 1987).

Both lower jaws are preserved, one in lateral view, the other in medial view (Fig. 14). Laterally, each jaw is formed by a large dentary anteriorly and the angular posteriorly; the suture between both bones is unclear due to poor preservation. The dentary is gently ascending posteriorly producing a posteriorly placed coronoid process; the oral margin of the dentary is covered by numerous, minuscule conical teeth. The medial view shows the articular bone and a large quantity of chondrified cartilage, possibly part of the Meckelian cartilage. The posterior opening of the mandibular sensory canal is placed medially. The postarticular process is elongated and well developed.

Hyomandibula, symplectic, quadrate, metapterygoid, entopterygoid, ectopterygoid, and part of the dermopalatine are preserved (Fig. 14). The hyomandibula preserves completely its dor- 


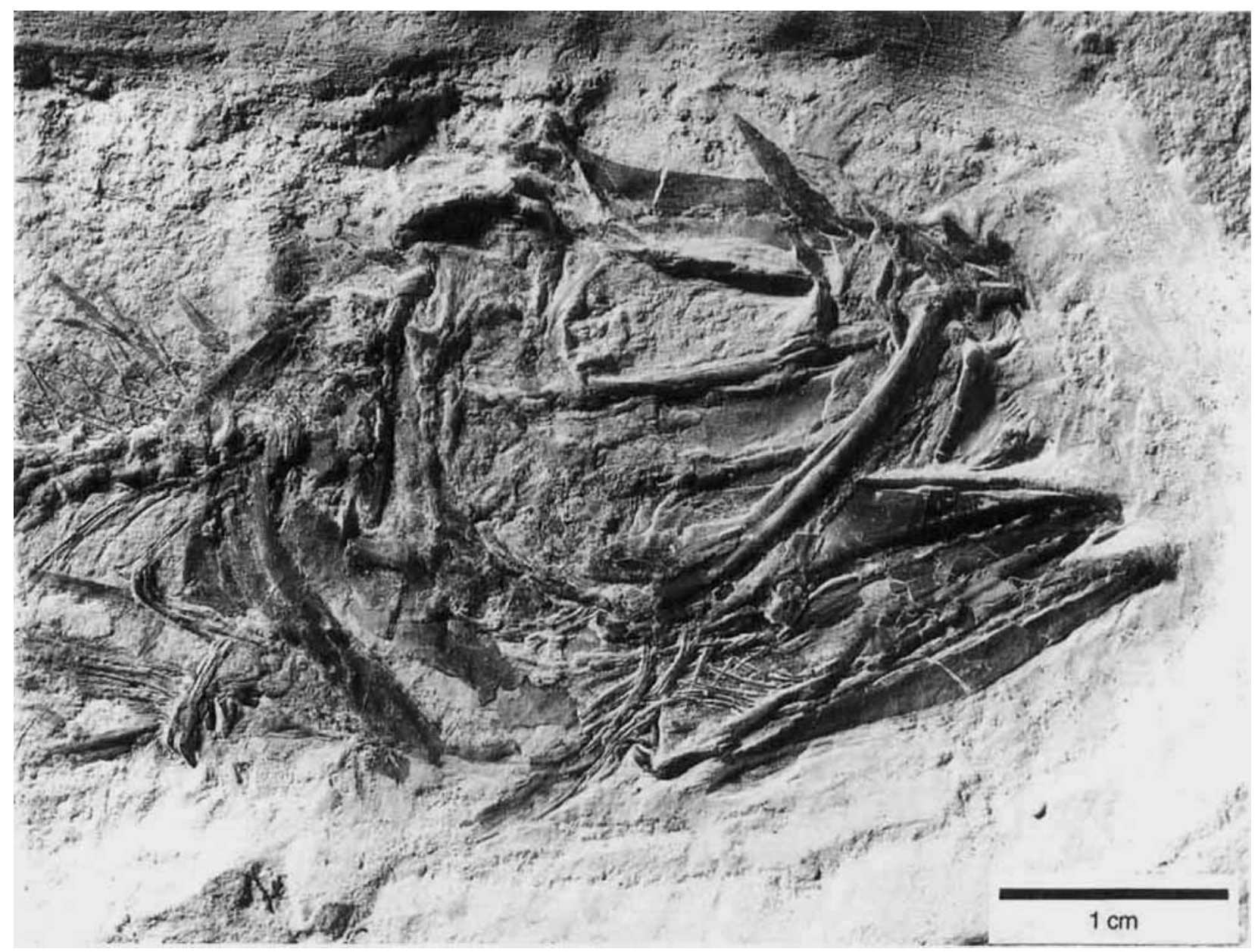

Fig. 13. †Anaethalion zapporum n. sp. from the Kimmeridgian of Schamhaupten, Bavaria. Head, pectoral girdle, and anterior abdominal vertebrae and associated elements in lateral view (JM SCHA 85)

sal part. Its lower part is partially covered laterally by metapterygoid and preopercle. The dorsal part is mainly chondral, but a section of the anterior membranous outgrowth extends anteriorly, close to the posterior limit of the orbit. It is unclear whether the bone has one or two articular facets for the neurocranium. A strongly inclined opercular process is present. The quadrate has its characteristic triangular shape, but it is not projected anteriorly as in †Elopsomolos frickhingeri $\mathrm{n}$. gen. and n. sp. (see below Fig. 17) and in Recent Elops (see Arratia \& Schultze 1991); the posteroventral process is short and sharp like in other $\dagger$ Anaethalion species and in Elops. The symplectic lies medially, between the main body of the quadrate and its posteroventral process. The ectopterygoid is boomerang-shaped as in Elops and bears minuscule teeth medially. A similar dentition is found in the medial side of the large entopterygoid. The metapterygoid is a large squarish bone, with a shape similar to that in Elops; it produces a dorsolateral crest separating the dorsal and ventral chondral regions of the bone. The crest produces a notch in its lateral margin; the processus basalis is incompletely preserved. There is an elongate, slightly displaced bone that is interpreted as the dermopalatine because of its position and the presence of numerous sockets for teeth, ventrally.

The elongate and oval gular plate (Fig. 14) is slightly broader posteriorly than anteriorly. The hyoid arch is not preserved, but branchiostegal rays of both arches (Figs 13, 14). The first branchiostegal rays are smaller than the posterior ones; their total number is unknown because conditions of incomplete preservation. The urohyal is partially covered, but is narrow anteriorly and expands posteriorly producing several projections.

The opercular bones are incompletely preserved. The preopercle (Fig. 14) is an almost triangular-shaped bone, with its ventral limb projected posteriorly and moderately expanded. Its posteroventral margin is slightly crenulated. Opercle and subopercle are narrow bones; the interopercle is destroyed. 


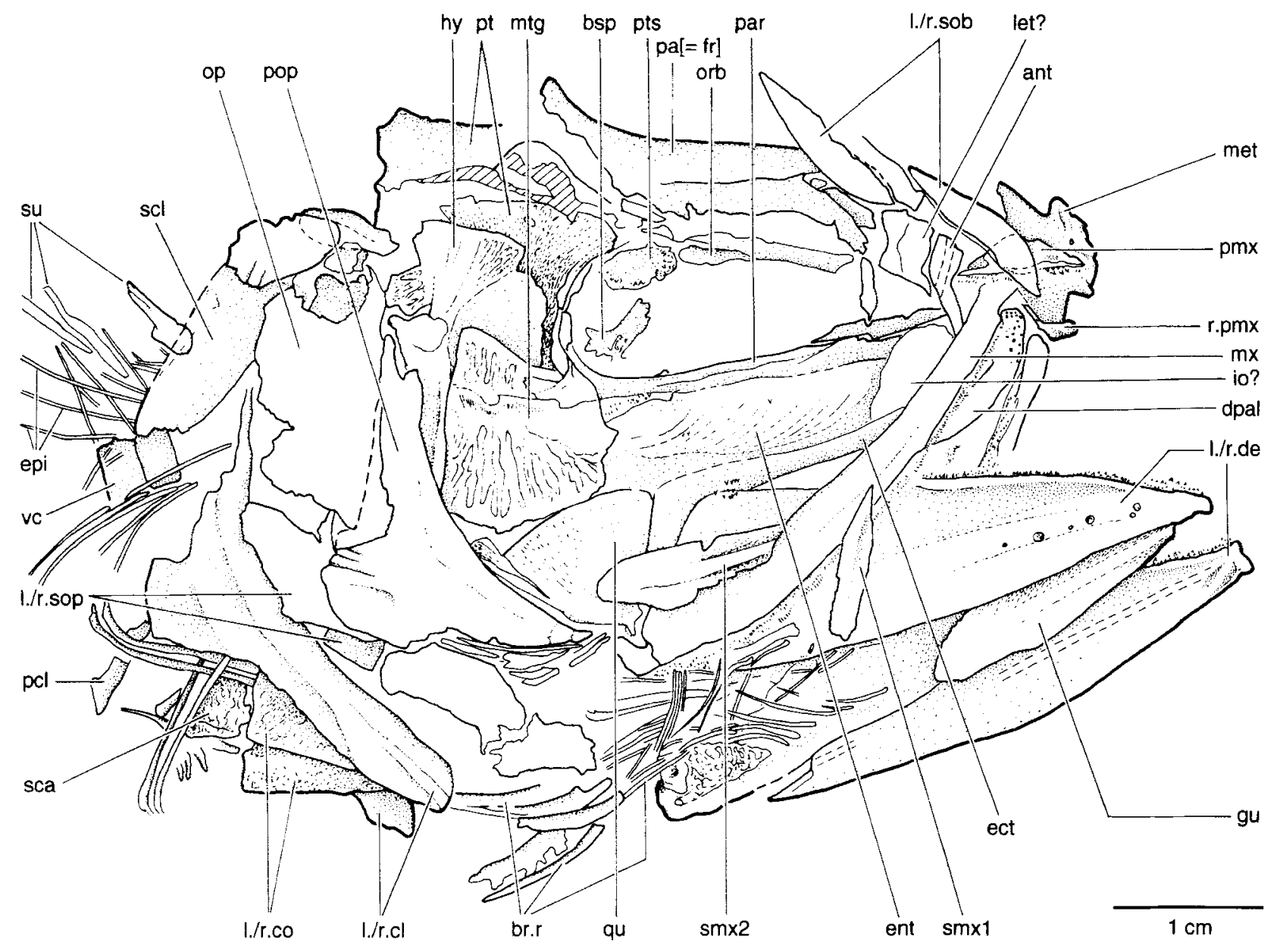

Fig. 14. †Anaethalion zapporum n. sp. from the Kimmeridgian of Schamhaupten. Bavaria. Head, pectoral girdle, and anterior abdominal vertebrae and associated bones in lateral view (JM SCHA 85).

ant, antorbital: br.r. branchiostegal ray: bsp. basisphenoid: dpal. dermopalatine: ect. ectopterygoid; ent, entopterygoid; epi, epipleural bone: gu. gular plate: hv. hyomandibula: io?. infraorbital bone?; let?, lateral ethmoid?; l./r.cl, left and right cleithrum: 1./r.co, left and right coracoid: 1./r.de. left and right dentary: $\mathbf{l} /$ r.sob. left and right suborbital bone; l./r.sop, left and right subopercle: met. mesethmoid: mtg. metapterygoid: mx. maxilla: op. opercle: orb. orbitosphenoid; par, parasphenoid; pcl, postcleithrum: pmx. premaxilla; pop. preopercle: pt. pterotic: qu. quadrate. r.pmx. remain of premaxilla; sca, scapula; smx1-2, supramaxillae 1-2: scl. supracleithrum: su. supraneural. vc. vertebral centrum

There are 47 vertebrae: 20 are caudals. The surface of all vertebral centra is ornamented with numerous longitudinal grooves and fine crests (Figs 11, 12). The neural arches of the abdominal vertebrae are autogenous and both halves of each arch are unfused medially: however, the neural and haemal arches are laterally fused to their centra and both halves of each neural arch are fused producing a single neural spine. Each abdominal centrum has ventrolateral cavities for articulation with ribs. Approximately 25 pairs of ribs are preserved.

Only the first three supraneural bones (Fig. 14) are observed; all others are covered by scales or are destroyed. They are elongate bones. The anterior epineurals (Figs 11. 12) are processes of the neural arches. They are long. slender, almost as long as the neural spines and completely ossified. Posteriormost epineurals lie almost parallel to the vertebral column; it is unclear whether they are processes of the neural arches or free bones. They reach posterior to the dorsal fin until vertebra 37 . Free dorsal intermuscular bones have not been observed posterior to the epineurals. A series of elongate, heavily ossified epipleural bones extends ventral to the vertebral centrum 29 until centrum 36 .

The pectoral girdle (Fig. 14) and fins are incompletely preserved. Part of the posttemporal bone, of the broad and large supracleithrum, of a strong and large cleithrum, and of one postcleithrum are preserved. The dorsal limb of the cleithrum is long, reaching dorsally above the level of the vertebral column. Two endochondral bones are preserved, part of the scapula and both coracoids. The pectoral rays are displaced, and their total number is unknown (more than 10 rays are present). Their bases are long, their 


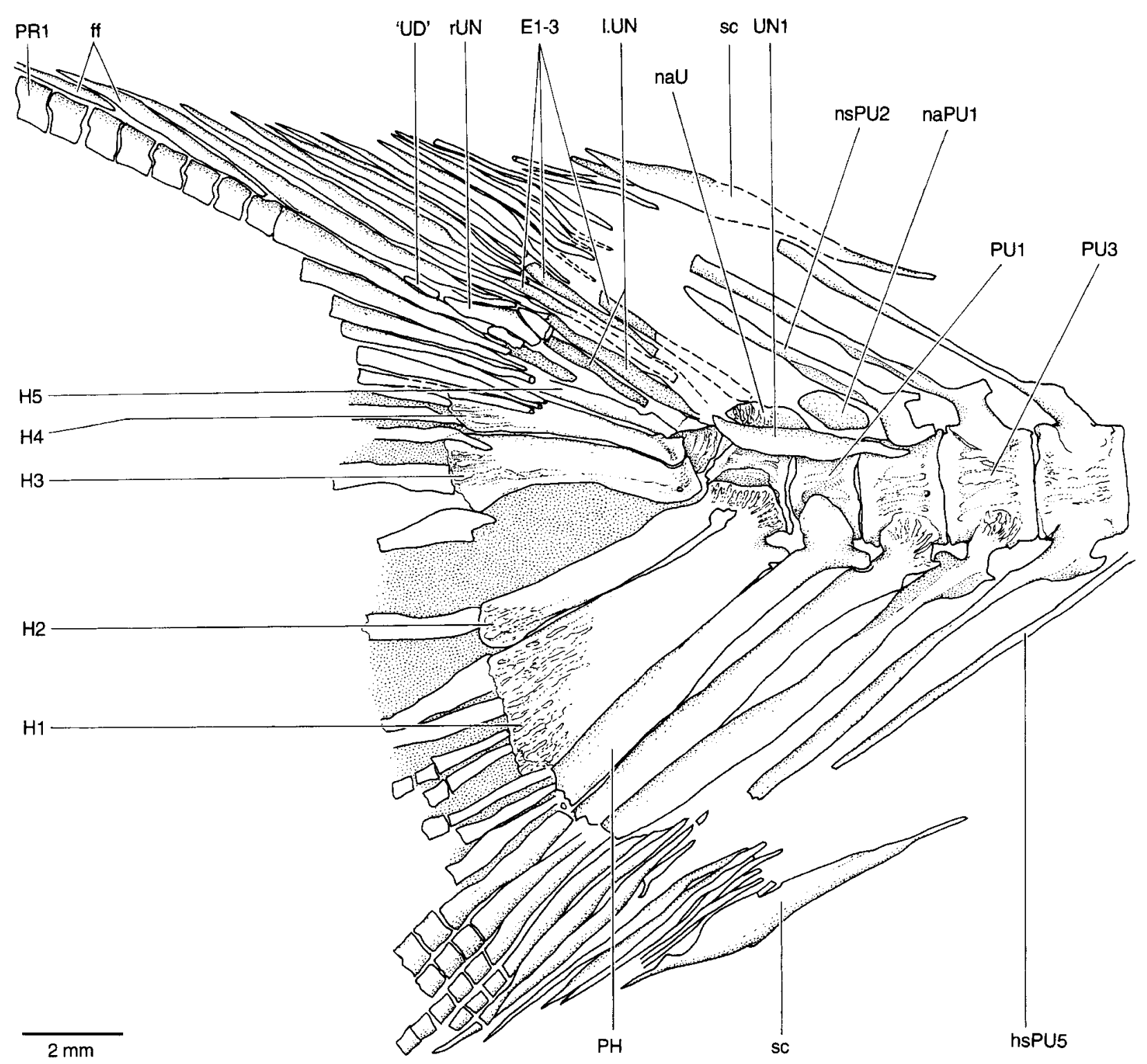

Fig. 15. †Anaethalion zapporum n. sp. from the Kimmeridgian of Schamhaupten, Bavaria. Caudal skeleton in lateral view (JM SCHA 85).

ff, fringing fulcra; hsPU5, haemal spine 5; H1-5, hypural 1-5; I.UN, left uroneural; naPU1, neural arch of preural centrum 1; naU, neural arch of 'first' ural centrum; nsPU2, neural spine of preural centrum 2; PH, parhypural; PR1, first principal caudal ray; rUN, right uroneural; sc, scute; 'UD', 'urodermal'; UN1, uroneural 1

distal ends are destroyed. The triangular pelvic bones are small and overlap each other. The total number of pelvic rays is unknown due to the overlapping of both fins (10 rays are counted in one fin).

The dorsal fin has four simple, small procurrent and 14 soft rays; there are 13 dorsal pterygiophores, the first one is trifurcated. The first proximal pterygiophores are elongated, extending ventrally between the neural spines; they become shorter caudally. The dorsal pterygiophores are formed by at least the proximal and middle elements; the middle elements are mainly cartilaginous. The anal fin has preserved four simple, small procurrent rays and 9 soft rays; there are
11 pterygiophores. The first pterygiophore is narrow and long, but it does not reach the vertebral column ventrally.

The caudal fin (Fig. 11) has both lobes of almost the same size and shape; its posterior margin is deeply concave. The caudal rays (Fig. 15) are supported by five preural vertebrae and ural centra. The size of the centra decreases strongly posteriorly, making preural centrum 1 the smallest of the caudal region. The surface of all these centra is ornamented by longitudinal grooves and fine crests. The neural arches of preural vertebrae, as well as the haemal arches, are broader posteriorly and containing a significant quantity of calcified cartilage surrounded by a fine peri- 
chondral ossification. Preural vertebra 1 lacks a neural spine. The haemal spines of preural centra 5-4 are elongated. and they are slightly narrower than the neural spines of preural centra 31. Hacmal arches 3-1 slightly project anteriorly. and bear an anterior process. as does the base of hypural 1. A hypurapophysis is not present at the haemal arch of the parhypural.

The 'first' ural centrum follows preural centrum 1; it is laterally articulated with hypurals 1 and 2. which are fused at their bases. [Because of its size and relation to the hypurals it is assumed here that this centrum corresponds to the fusion of ural centra 1 and 2 following the polyural terminology (for details see Schultze \& Arratia 1989 and Arratia \& Schultze 1992)]. There is another, heavily ossified ural centrum whose complete size is unknown because it is partially covered by the hypurals and uroneurals. An elongate arch, retaining chondrified cartilage lies above the 'first' ural centrum.

Four incomplete uroneurals (Fig. 15) are preserved. The first one reaches preural centrum 2; the bone is slightly expanded anteriorly. The other uroneurals are very damaged.

Three incomplete epurals are observed: they are elongated, narrow bones.

Five hypurals (Fig. 15) are preserved: the dorsal hypurals are covered by the bases of dorsal principal rays. Hypural 1 is the broadest of the series. Hypural 2 is as long as hypurals 1.3 and 4. There is a broad diastema betw'een hypurals 2 and 3 . The base of hypural 3 articulates with the 'first' and 'second' ural centra.

An oval 'urodermal' is present.

There are 14 epaxial procurrent rays (or epaxial basal fulcra?), two dorsal fringing fulcra. 10 dorsal and 9 ventral principal rays. and about 10 ventral procurrent rays. four of which are segmented. The bases of most rays are incompletely preserved so that it is unknown whether a dorsal process was present at the base of some of the dorsal principal rays. The segmentation of the principal rays is Z- or step-like. The dorsal and ventral scutes are long and narrow: both reach the neural and haemal spines of preural vertebra 6 , respectively.

The last caudal vertebrae produce a slight dorsal flexion.

The cycloid scales are incompletely preserved. and no isolated ones are found.

Comparison and discussion: The new species of $\dagger$ Anaethalion from Schamhaupten differs slightly from other species of the genus in body propor- tions. It shares with $\dagger$ Anaethalion angustus and $\uparrow A$. knorri the position of the quadrate-mandibular articulation (below the posterior half of the orbit) and a maxilla that reaches the quadrate (both characters used in a key for identification of species of $\dagger$ Anaethalion proposed by Arratia 1987a: 25). However, it differs from both species in the anterior position of the anal fin insertion ( $71 \%$ of $\mathrm{SL}$ ); in contrast, in $\dagger A$. angustus it is between 79 to $84 \%$ of SL and in $\dagger A$. knorri it is between 74 to $79 \%$ of SL. It differs from all species of $\dagger$ Anathalion from the Late Tithonian in the lower number of vertebrae (47). $\dagger A$. angustus has $49-53 ; \dagger A$. knorri and $\dagger A$. cf. A. subovatus have 51-52; and $\dagger A$. angustissimus has 51 vertebrae (Arratia 1987a: tab. 1). The preopercle of $\dagger$ Anathalion is not expanded as the bone is in Recent elopiforms (Arratia 1997); the ventral limb is moderately expanded and has few sensory tubules that are short, not reaching the posteroventral margin of the preopercle. In contrast, $\dagger$ Anaethalion zapporum n. sp. has a preopercle moderately expanded and its posterior margin is slightly crenulated.

For information on the phylogenetic relationships of $\uparrow$ Anaethalion zapporum see below.

Division Teleostei sensu Arratia, 1999

Supercohort Elopomorpha sensu Arratia, 1997

Order Elopiformes Greenwood et al., 1966

Family Elopidae Bonaparte, 1846

\section{${ }_{\dagger}$ Elopsomolos n. gen.}

Diagnosis (based on a combination of features): Elongate fishes with very short neural and haemal spines. Enlarged and posteriorly expanded preopercle; preopercular sensory canal with numerous and elongate sensory tubules reaching ventroposterior margin of bone. Broadly expanded posterior infraorbital bones. Anterior ceratohyal fenestrated. About 47 to 53 vertebrae. with strongly ornamented autocentra with elongate ridges and grooves or with numerous foramina. Dorsal limb of cleithrum short, not reaching level of vertebral column. Few fringing fulcra (ca. 3).

Etymology: Refers to the overal similarity of the new fossil genus to extant Elops; ending omolos $($ Greek $)=$ similar.

Content: $\nmid$ Elopsomolos frickhingeri n. sp. (type-species) and probably three other forms previously described as †Elops-like sp. 1 from 
the Kimmeridgian of Schamhaupten, and $\dagger$ Elopslike sp. 2 and sp. 3 from the Tithonian, Malm Z2, Solnhofen Limestone (Arratia 1997). †Elopslike spp. are identified here as †Elopsomolos sp. 1, sp. 2 and sp. 3.

\section{$\dagger$ Elopsomolos frickhingeri n. sp.}

Figs 16-20

Diagnosis: The new species differs from other species of $\dagger$ Elopsomolos and Elops in the following combination of features: Preopercle moderately expanded posteriorly and ventral limb with numerous, branched sensory tubules reaching the margin of the ventral limb. With about 52 vertebrae; reduced number of caudal vertebrae $(\sim 17)$ versus a high number of abdominal vertebrae $(\sim 35)$; consequently, large pleuroperitoneal cavity [*]. Heavily ossified centra, with smooth surfaces and with numerous small foramina [*]. Dorsal fin origin slightly anterior to pelvic fin origin. Neural spines of preural centra moderately inclined toward the horizontal. Neural spine of preural centrum 1 long [*]. Hypurals 1 and 2 fused with 'first' ural centrum [*]. (Unique characters among †Elopsomolos and Elops are identified by $\left[{ }^{*}\right]$.)
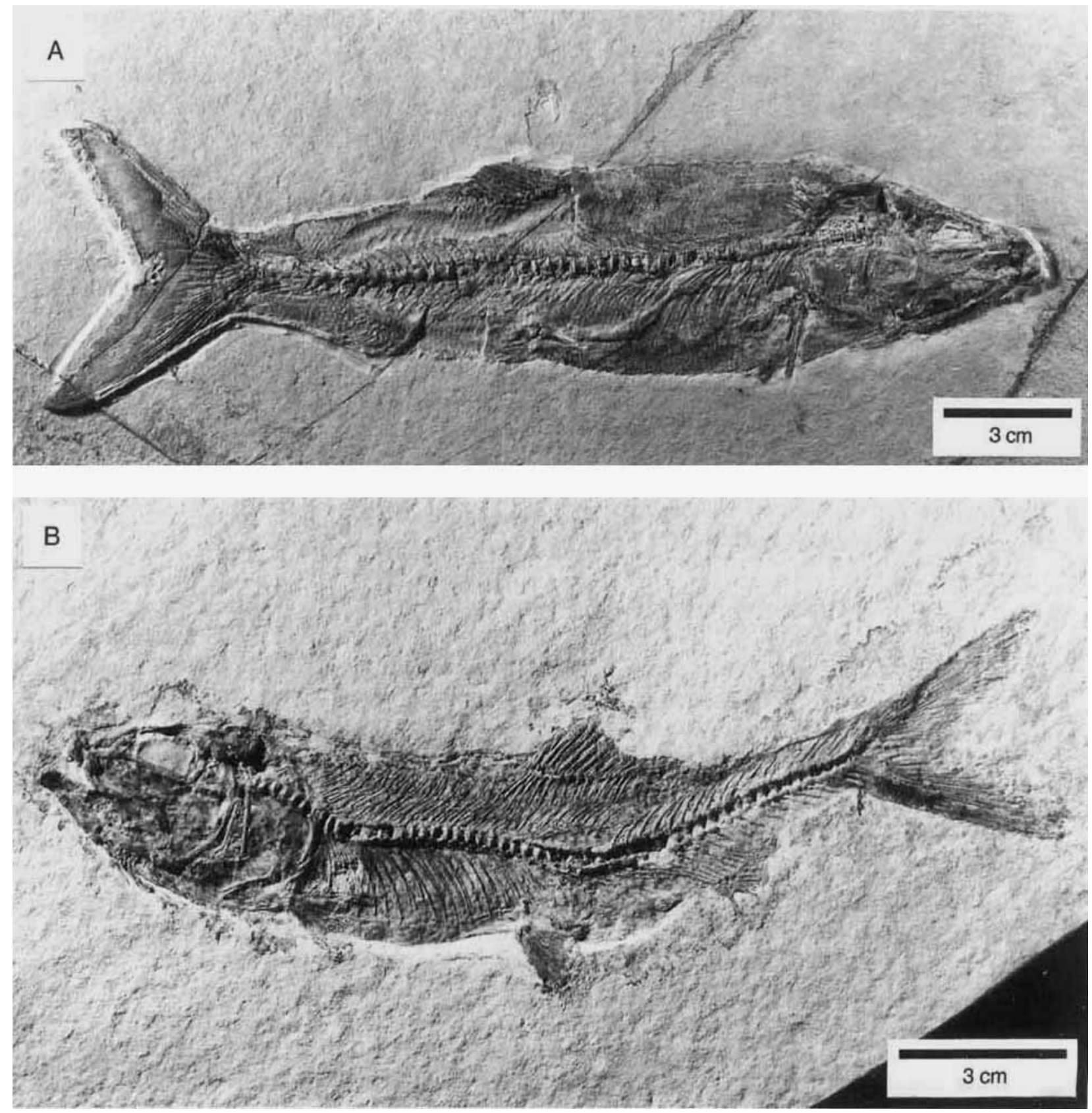

Fig. 16. †Elopsomolos frickhingeri n. gen. et n. sp. from the Upper Jurassic, Tithonian, Malm Z2 of Blumemberg. Bavaria. A Holotype (JM SOS 4393) in lateral view. B. Paratype MB. f.7578 


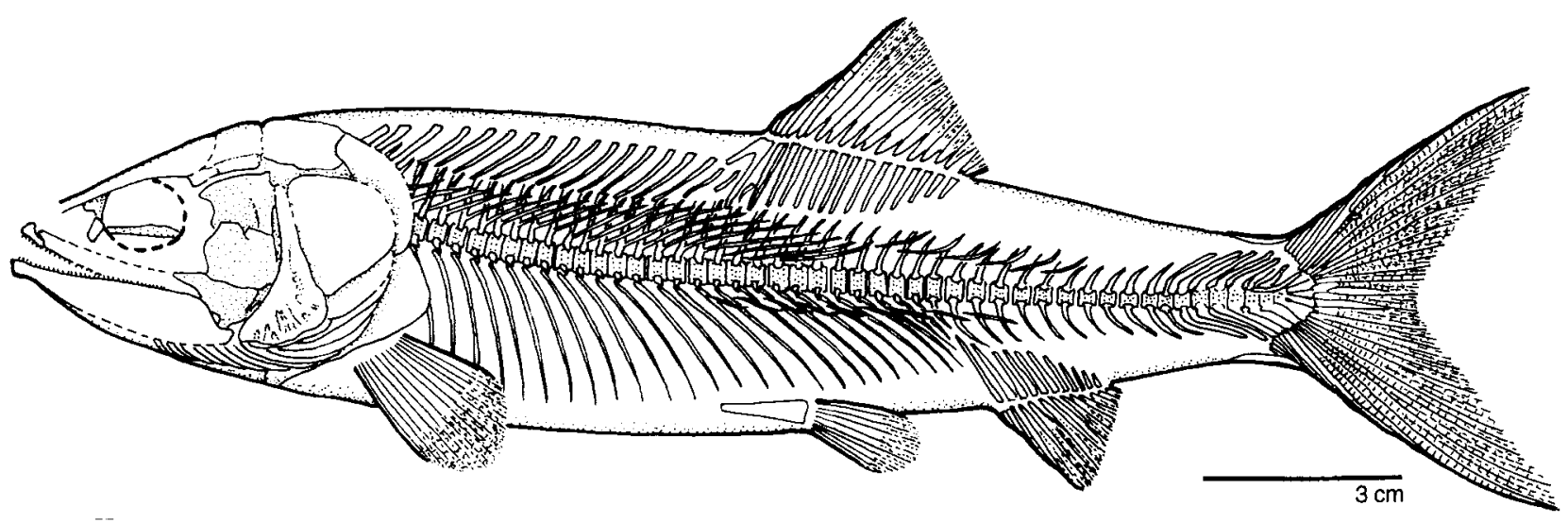

Fig. 17. †Elopsomolos frickhingeri $\mathrm{n}$. gen. and n. sp. from the Upper Jurassic. Tithonian. Malm Z2 of Blumemberg, Bavaria. Restoration in lateral view based mainly on the holotype (JM SOS 4393): reversed to the left. Supraneural bones and dorsal and anal fins are from the paratype (MB. f.7578)

Holotype: JM SOS 4393, complete adult specimen (Fig. 16A) lacking tips of the fin rays.

Paratype: MB. f.7578 a, b, complete juvenile specimen (Fig. 16B), preserved in part and counterpart.

Type locality and age: The holotype was recovered in Blumenberg, near the town of Eichstätt (Fig. 1). The paratype has an unknown provedence in the Solnhofen Limestone. Late Jurassic, Tithonian, Malm Z2.

Etymology: The specific name honors $\mathrm{Mr}$. Karl Frickhinger (Emmering, Germany) because of his contribution to the knowledge of the fauna of the Solnhofen Limestone and because of the gift of some specimens, including the paratype of the new species.

Description: The elongate fish (Figs 16,17) of about $24 \mathrm{~cm}$ total length and $19.7 \mathrm{~cm}$ standard length (SL) has a proportionately long head (head length about 3.6 times $=27.4 \%$ in SL). The head is deep at the level of the opercular region and is markly pointed anteriorly. The orbital cavity is small (about $20 \%$ of head length). The anterior part of the trunk is deeper than the head with maximum depth just behind head. Maximum body depth is $24.3 \%$ of SL. The caudal peduncle is narrow, about half of maximum body depth. Predorsal length is $55.5 \%$ of SL. The dorsal fin originates slightly posterior to half of SL. Prepelvic length is $59.8 \%$ of SL. The origin of the pelvic fins lies slightly posterior to that of the dorsal fin; this condition is observed also in some species of Recent Elops (e.g., E. hawaiensis, and some specimens of E. saurus) and in $\dagger$ Davichthys dubius (Forey 1973: fig. 13). Preanal length is $75 \%$ of SL. The tips of the dorsal and anal fins of the holo- type were destroyed, I suppose, during preparation, because part of the surrounding areas of the fish have been deeply marked in the rock.

Most head bones (Fig. 18) are poorly preserved. The incomplete and elongate parietal bone [ $=$ so-called frontal] does not show the trajectory of the supraorbital sensory canal. Lateral to the parietal remains of the lateral ethmoid are present. The parietal sutures posteriorly with two bones which are interpreted as the pterotic and postparietal. The suture between pterotic and parietal is only partially preserved. The nasal bone and the autosphenotic are not preserved.

The parasphenoid is partially seen. It is unclear whether it bears dentition or not because there are minuscule teeth scattered in the region below the parasphenoid and entopterygoid.

The orbital bones are damaged. However, the paratype preserved a slightly elongate antorbital bone.

The upper jaw (Fig. 18) has preserved parts of the maxillae which bear small villiform teeth. Both lower jaws are incomplete. Each lower jaw (Fig. 18) is elongated and its overall shape is similar to that in $\dagger$ Anaethalion and in Elops. The lateral view of the jaw shows a large dentary and the angular which projects posteriorly in the postarticular process. The suture between dentary and angular is unclear due to incomplete preservation. No exit foramen for the mandibular canal is observed laterally; thus, it is assumed here that the canal exits medially as in $\dagger$ Anaethalion and Elops. The posteroventral part of the dentary extends posteriorly, almost reaching the posterior margin of the jaw; part of the mandibular canal is observed at its middle posterior part. A piece of a chondral bone is visible between the condyle of quadrate and the angular; 
this is interpreted here as part of the articular.

The quadrate-mandibular articulation is posteriorly placed behind the orbit, like the condition in †Anaethalion, †Eichstaettia, Elops, and other elopids. The quadrate (Fig. 18) is a large, triangular bone with its anterodorsal tip projected anteriorly. The posteroventral process is short and sharp and the articular condyle small, resembling the general aspect of the quadrate of Elops (Arratia \& Schultze 1991: fig. 24). The quadrate sutures with a large, squarish chondral bone, the metapterygoid. Although part of the dorsal margin of the metapterygoid is damaged, the presence of both the notch and the processus basalis are evident. A small portion of the hyomandibula (Fig. 18) is preserved, but it is not informative.

The preopercle (Fig. 18) is broad, with its ventral limb bearing numerous ramifications of the preopercular sensory canal that reach close to the ventral margin where they exit through small pores. The posterior margin of the bone is not crenulate like in Elops (Arratia 1987a, 1997). It is assumed here, based on the position of the cleithrum, that the opercle was also an expanded bone. The subopercle seems to be narrow, but it bears a well developed anterodorsal process. The interopercle, apparently, is also moderately narrow. The branchiostegal series (Fig. 18) is incomplete: about 14 rays are preserved; the first one is short and slender, and the following rays become broader and longer posteriorly.

The vertebral column (Figs 16, 17) has about 52 vertebrae including the preural centrum 1 ; the number of caudal vertebrae (17) is half that of abdominal ones. The centra are heavily ossified and ornamented with numerous small, round foramina which become more numerous caudally. The abdominal centra have small articular dorsal cavities for the neural arches and ventrolateral short parapophyses for the articulation of the ribs. The parapophyses enlarge a little posteriorly. Both halves of the neural arches remain unfused in the abdominal region, becoming

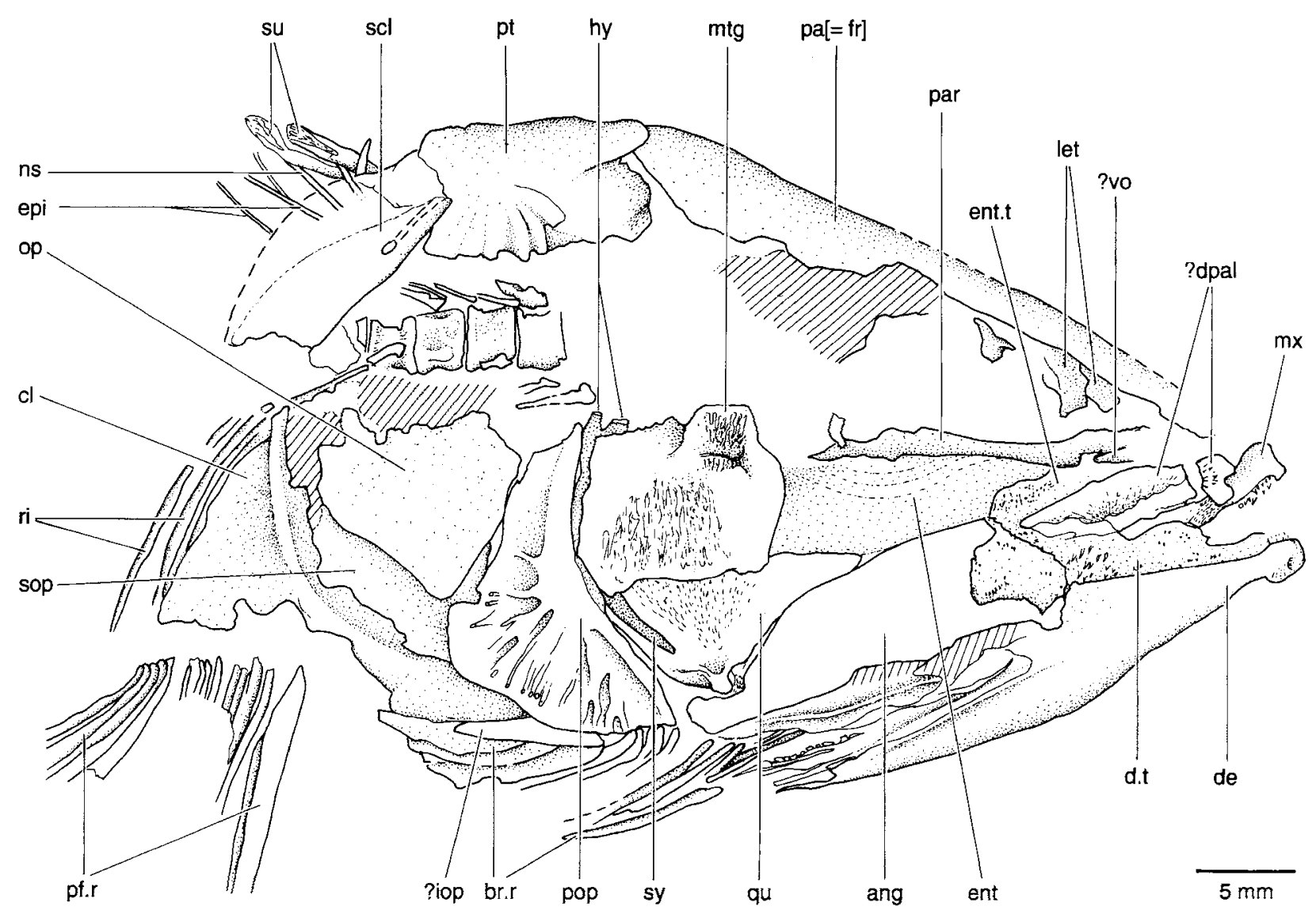

Fig. 18. $\dagger$ Elopsomolos frickhingeri n. gen. and n. sp. from the Upper Jurassic, Tithonian, Malm Z2 of Blumemberg, Bavaria. Head, pectoral girdle, first vertebrae and associated elements in lateral view (JM SOS 4393).

ang, angular; br.r, branchiostegal ray; cl, cleitrum; de, dentary; d.t, dentary teeth; ?dpal, dermopalatine?; ent, entopterygoid; ent.t, entopterygoid teeth; epi, epineural bone; hy, hyomandibula; ?iop, interopercle?; let, lateral ethmoid; mtg, metapterygoid; mx, maxilla; ns, neural spine; op, opercle; pa[= fr], parietal bone [so-called frontal bone]; par, parasphenoid; pf.r, pectoral fin rays; pop, preopercle; pt, posttemporal; qu, quadrate; ri, rib; scl, supracleitrum; sop, subopercle; su, supraneural bone; sy, symplectic; ?vo, vomer? 
fused into one neural spine in the caudal region. The caudal vertebrae have unfused neural and haemal arches with the exception of most preural vertebrae and 'first' ural centrum with fused neural and haemal arches. Neural and haemal spines of the caudal region are very short (Figs $16,17)$; the first ones are slightly inclined toward the axis of the column. but the most posterior ones are progressively inclined toward the horizontal. Each rib is heavily ossified, with a small rectangular base bearing a facet for the articulation in the ventrolateral cavity of the centrum. The anterior ribs are slightly longer than the most posterior ones, but still they do not reach the ventral margin of the body.

Only the first two supraneural bones (Fig. 18) are observed in the holotype: all others are covered by scales. However. a complete series of supraneurals extending from the occiput to the second dorsal pterygiophore is present in the paratype. They are elongate. delicate bones. slightly broader distally. The anterior epineurals are processes of the neural arches. It is unclear whether the last epineurals (Figs 16.17) are independent bones or processes of the neural arches. They are long, slender. heavily ossified. and become longer posteriorly. each extending, at least, over five arches. They reach until the middle region of the dorsal fin and then are replaced by a series of free intermuscular bones lying dorsal to the vertebral column. from vertebra 33 until vertebra 38. A series of elongate. heavily ossified epipleural bones (Fig. 17) extends ventral to the vertebral centrum 22 until the centrum 38 .

The pectoral girdle (Fig. 18) and fins are incompletely preserved. Part of the broad. large posttemporal and supracleithrum and of a strong, short, and broad cleithrum are preserved. The dorsal limb of the cleithrum does not reach the level of the vertebral column. Fourteen pectoral rays are counted in the holotype and about 12 in the paratype. Their bases are long. and their distal ends are finely branched. The triangular pelvic bone is small. Nine broad pelvic rays are preserved in the holotype and about 10 in the paratype. They have long bases, but their distal ends are incomplete.

The dorsal fin has its distal tip destroyed: 17 dorsal rays but no pterygiophores are preserved in the holotype. The dorsal pterygiophores are preserved in the paratype. The anal rays are damaged but the anal pterygiophores are preserved in the holotype. Fourteen anal rays are observed in the paratype.
The caudal fin (Fig. 19) has both lobes of almost the same size and shape; its posterior margin is deeply concave. The caudal rays are supported by five preural and ural vertebrae. The sizes of the centra decrease strongly posteriorly, making preural centrum 1 the smallest of the caudal region. The surface of all these centra is ornamented with small foramina. The neural arches as well as the haemal arches are broad and containing a significant quantity of calcified cartilage surrounded by a fine perichondral ossification. The neural spines of preural vertebrae 5-3 are elongated; the neural spines of preural centra 2-1 are also elongate, but they are slightly narrower distally. The haemal spines of centra 5-3 are elongated, and they are slightly narrower than the neural spines of preural centra 2-1. Haemal arches 3-1 slightly project anteriorly as does the base of hypural 1 . It is possible that a hypurapophysis was present because the haemal arch of the parhypural is projected laterally, but the projection is partially damaged.

The 'first' ural centrum (Fig. 19) is fused to hypurals 1 and 2. Because of its size and relation to the hypurals it is assumed here that this centrum corresponds to the fusion of ural centra 1 and 2 following the polyural terminology (for details see Schultze \& Arratia 1989 and Arratia \& Schultze 1992). There is another, heavily ossified ural centrum whose complete size is unknown because it is partially covered by the displaced hypural 4 and an uroneural. Remains of arches and spines have not been observed above the ural centra.

Three incomplete uroneurals (Fig. 19) are observed in the holotype, and two are preserved in the paratype. The first one reaches preural centrum 2; it is possible to state that is expanded anteriorly despite that the bone is broken. The other two uroneurals of the holotype have very different sizes. The bone interpreted here as uroneural 2 , by comparison with uroneural 2 of the paratype, of $\uparrow$ Anaethalion, Elops, and $\uparrow$ Daitingichthys, is broad; unfortunately its anterior tip is broken so that it is not possible to determine whether it reaches the 'first' ural centrum or not. Uroneural 3 is small and fusiform.

Three incomplete epurals are present. The epurals are thought to be long bones because of the size of the remains.

Four hypurals (Fig. 19) are observed in the holotype: most of the dorsal hypurals are covered by the bases of dorsal principal rays so that their total number is unknown. However, some of the dorsal principal rays are broken in the paratype, 


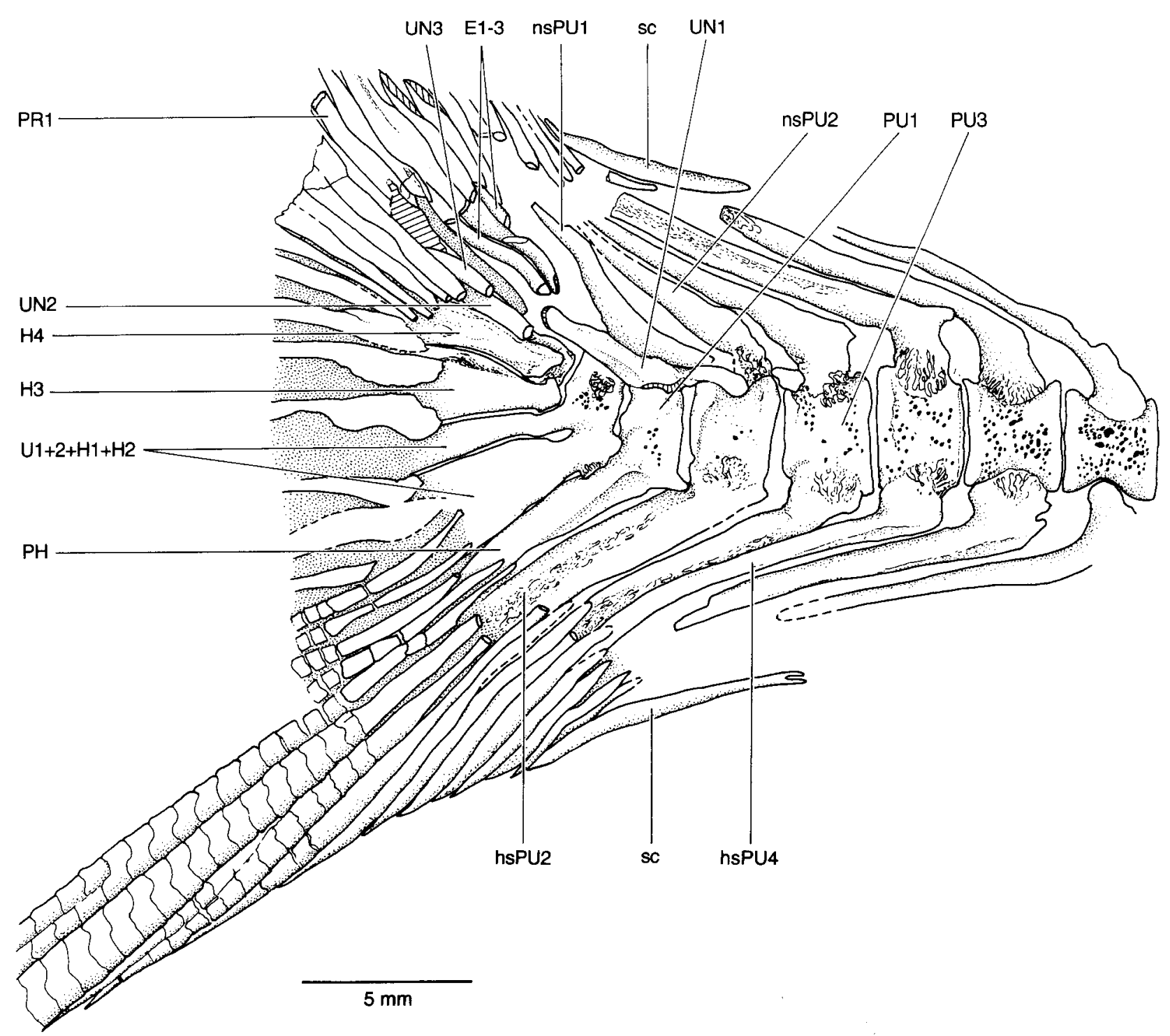

Fig. 19. †Elopsomolos frickhingeri n. gen. and n. sp. from the Upper Jurassic, Tithonian, Malm Z2 of Blumemberg, Bavaria. Caudal skeleton in lateral view (JM SOS 4393).

E1-3, epural 1-3; H1-4, hypural 1-4; hsPU2-4, haemal spine of preural centrum 2-4; nsPU1-2, neural spine of preural centrum 1-2; PH, parhypural; PR1, first principal caudal ray; PU1-3, preural centrum 1-3; sc, scute; U1+2+H1+H2, 'first' ural centrum fused with the bases of hypurals 1 and 2 ; UN1-3, uroneural 1-3

and therefore, it is possible to observe six hypurals; the last ones being very small. Hypural 1 is the broadest of the series and hypural 2 the narrowest. There is no diastema between hypurals 2 and 3 . The base of hypural 3 lies against the base of hypural 2 and articulates with the 'second' ural centrum. The bone interpreted as hypural 4 is as broad as hypural 3 and has an unusual large base.

Because of incomplete preservation, it is unknown whether 'urodermals' were present or not in the holotype; one oval-shaped 'urodermal' is present on the lateral aspect of the first dorsal and second principal caudal rays in the paratype.

There are 11 or 12 epaxial procurrent (incompletely preserved distally), 10 dorsal and 9 ven- tral principal, and 10 ventral procurrent rays, two of which are segmented. The bases of some rays are partially damaged so that it is unknown whether a dorsal process was present at the base of some of the inner dorsal principal rays. The bases of the innermost rays were slightly expanded. The principal rays have short bases, numerous short segments, and their segmentation is $Z$ - or step-like. The dorsal and ventral scutes are long and narrow; the ventral one reaches the haemal spine of preural vertebra 6. Part of the rays anterodorsal to the first principal ray are destroyed in the holotype, so that it is unknown whether fringing fulcra are present or not. The paratype, with the dorsal margin of the dorsal lobe of the caudal fin preserved, shows that one 
small fringing fulcrum is present (probably three).

The vertebral column shows an abrupt dorsal flexion at the level of preural centrum 1/'first' ural centrum.

The relatively small scales (Fig. 20) are strongly imbricated and no isolated ones are found. They are cycloid, with numerous circuli in the anterior and posterior fields. It is assumed here that they have crenulated posterior margins.

A section of the intestinal contents (Fig. 16A) is preserved under the scales in both specimens.

Comparison and discussion: Several elopomorphs are known from the Upper Jurassic (Tithonian) of Bavaria. They include the genera $\dagger$ Anaethalion with four species, Elops-like sp. 2, Elops-like sp. 3 (here identified as $\dagger$ Elopsomolos sp. 2 and sp. 3), and probably $\dagger$ Eichstaettia and $\nmid$ Daitingichthys, each with only one species (Arratia 1987a, 1991, 1997).

The differentiation between $\dagger$ Anaethalion, $\dagger$ Elopsomolos, and Elops is not easy because these fishes have a generalized morphology, and they often exhibit curious combinations of characters.

There are few characters to distinguish $\dagger$ Anaethalion from $\nmid$ Elopsomolos and Elops. Some of the characters are: 1) the small and narrow preopercular bone of $\dagger$ Anaethalion in comparison to the enlarged and expanded preopercle of $\dagger$ Elopsomolos and Elops (see Arratia 1987a: text-fig. 30, 1997: figs 26, 27, 28A, 31, 36D). (2) The few, short sensory tubules on the preopercle of $\uparrow$ Anaethalion distinguish them from the elongate and numerous sensory tubules in the preopercle of $\dagger$ Elopsomolos and Elops. (3) The posterior infraorbital bones are broad in $\uparrow$ Elopsomolos and

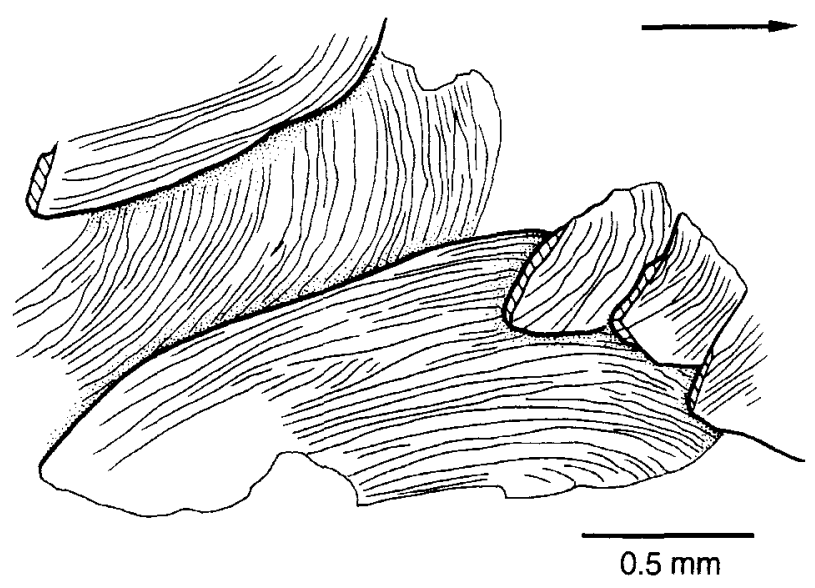

Fig. 20. Elopsomolos frickhingeri n. gen. and n. sp. from the Upper Jurassic, Tithonian. Malm Z2 of Blumemberg. Bavaria. Scales from the ventral part of the caudal peduncle (JM SOS 4393). Arrow points anteriorly
Elops, whereas they are narrow in $\dagger$ Anaethalion. (4) $\dagger$ Anaethalion and $\dagger$ Elopsomolos sp. 3 present a fenestra in the anterior ceratohyal (Arratia 1997: figs 31, 33B); the fenestra is missing in Elops. (5) The dorsal limb of the cleithrum is long in $\dagger$ Anaethalion, whereas it is short, not reaching the vertebral column in $\dagger$ Elopsomolos and Elops. (6) The number of vertebrae of $\dagger$ Anaethalion (between 47 and 53) is more similar to that of $\nmid$ Elopsomolos; in contrast, Elops has a high number of vertebrae, averaging 75 . However, the proportion of these vertebrae varies between the groups. (7) $\dagger$ Anaethalion and $\dagger$ Elopsomolos have about three epaxial fringing fulcra, whereas Elops lacks them. (8) The short, leaf-like neural spine of preural centrum 2 resembles more closely that in Elops than the spine in $\nmid$ Anaethalion. For more details see Arratia (1997: 57-60).

The genus $\dagger$ Eichstaettia is known from two specimens deposited at the Jura Museum and several specimens that belong to private collectors. The specimens of $†$ Eichstaettia were previously included in $\dagger$ Anaethalion by Nybelin (1967) because of the general resemblance in jaws and teeth. These fishes were included in a new genus, $\nmid$ Eischstaettia, by Arratia (1987a) due to the presence of a narrow elongate body (maximum body depth $15-17 \%$ of standard length) and the remarkable morphology of the most posterior caudal vertebrae and the caudal skeleton. Unfortunately, the poor preservation of the head of the specimens of + Eichstaettia does not permit knowledge of the shape of the preopercle, the patterns of the preopercular sensory canal and posterior infraorbitals.

The new fish shows a curious combination of features that makes its taxonomic assignment difficult. The fish shares with $\uparrow$ Anaethalion, $\nmid$ Elopsomolos, and $\dagger$ Eichstaettia an elongate body with very short neural and haemal spines, the presence of elongate jaws bearing numerous villiform teeth (which also are found in the ectoand entopterygoid), and two uroneurals extending forward beyond the 'second' ural centrum.

Two $†$ Elopsomolos species ( $\dagger$ Elopsomolos sp. 2 and sp. 3) are known from the Tithonian Malm Z2 of Bavaria (Arratia 1997). †Elopsomolos sp. 2 (based on BMNH 37048) was first identified as Elops-like by Nybelin (1963) because of similarities between the caudal skeleton of the fossil specimen and Recent Elops. Later, Nybelin (1967) reassigned this specimen to $\dagger$ Anaethalion sp. without presenting arguments. In 1971, he recognized that the cranial bones are defective and 
that the rostral bone and the well preserved caudal skeleton are more similar to Elops than to $\dagger$ Anaethalion, whereas the preopercle is more similar to that in $\dagger$ Anaethalion. Based mainly on the structure of the caudal skeleton, Arratia (1997: fig. 29A, B) reinterpreted it as Elops-like sp. 2.

$\dagger$ Elopsomolos sp. 3 is based on two well preserved specimens (Arratia 1997: 50-56). $\dagger$ Elopsomolos sp. 2 and sp. 3 differ mainly in the structure of the caudal skeleton.

The new fish cannot be assigned to †Elopsomolos sp. 2 or sp. 3 because of the following additional differences: (1) Number of vertebrae. Although the total number of vertebrae in most teleostean species is commonly variable, $\uparrow$ Elopsomolos presents a number of vertebrae closer to species of $\dagger$ Anaethalion (47-55) than to Recent Elops (over 70). For instance, $\nmid$ Elopsomolos sp. 2 has about 49 vertebrae, $\dagger$ Elopsomolos sp. 3 has about 51, and $\dagger$ Elopsomolos frickhingeri $\mathrm{n}$. gen. and $\mathrm{n}$. sp. has about 52. However, the proportion between abdominal and caudal vertebrae varies in these forms. For instance, the number of $a b-$ dominal and caudal vertebrae is more or less similar in $\dagger$ Anaethalion; in contrast, a reduced number of caudal vertebrae in comparison to the abdominal ones (double in number) is found in $\dagger$ Elopsomolos frickhingeri n. gen. and n. sp. There are more abdominal vertebrae (about twice as many) than caudal vertebrae in Elops (about 30). (2) In †Elopsomolos frickhingeri n. gen. and n. sp., the haemal arches of preural centra 2-1 and hypurals 1 and 2 are fused to their respective centrum; they are unfused in $\dagger$ Elopsomolos sp. 3. (3) The neural spine of preural centrum 1 is long in †Elopsomolos frickhingeri $\mathbf{n}$. gen. and n. sp.; it is absent in †Elopsomolos sp. 2. The condition is unknown in $\dagger$ Elopsomolos sp. 3.

The position of the dorsal fin in the new fish cannot be compared with that in $\dagger$ Elopsomolos sp. 2 and sp. 3 because of incomplete preservation of the last two forms. An anterior position of the dorsal fin is also observed in species of Elops and other elopomorphs such as $\dagger D a$ vichthys (Forey 1973: fig. 13), †Anaethalion cf. A. subovatus (Arratia 1987a), and Albula vulpes. $\dagger$ Anaethalion angustus has this feature according to the restoration by Poyato-Ariza (1999: fig. 4); however, according to my observations, commonly the origins of both dorsal and pelvic fins are opposite.

In conclusion, the new fish is an elopiform which differs from previously described Elopslike forms (=†Elopsomolos n. gen.) from the
Malm Z2 of Bavaria and therefore is identified in a preliminary way as $\dagger$ Elopsomolos frickhingeri $\mathrm{n}$. gen. and n. sp.

\section{Phylogenetic relationships of $\dagger$ Ascalabothrissops n. gen. and $\nmid$ Anaethalion zapporum n. sp.}

The phylogenetic relationships of $\dagger$ Ascalabothrissops voelkli $\mathrm{n}$. gen. and $\mathrm{n}$. $\mathrm{sp}$. and of $\dagger$ Anaethalion zapporum $\mathrm{n}$. $\mathrm{sp}$. are explored using cladistic methodology. Two analyses are performed. The first analysis includes selected primitive fossil and extant teleosts to investigate the phylogenetic relationships of the new Late Jurassic teleosts described here. The second analysis investigates the relationships of the fossil elopiforms studied.

\section{First cladistic analysis: Fossil and extant teleosts}

This analysis is based on 191 characters (see Appendix 1 and Table 1) and 47 taxa of which 36 are ingroup taxa. The trees are rooted using user-specified outgroup methods, but there is no difference in the topology of the teleosts when using different outgroup methods.

Figure 21 corresponds to the single shortest tree at 666 evolutionary steps. The consistency index is 0.417 . To facilitate the reading, I will represent the nodes for non-teleostean fishes by numbers and the teleostean nodes by letters. Nodes 1 to 3 correspond to the relationships among members of the outgroup. For characters supporting nodes see explanation of Figure 21.

The teleostean nodes represent the following steps in Figure 21.

Node A corresponds to the branching between $\dagger$ Pholidophorus bechei and all other teleosts. This node is supported by three uniquely derived characters (quadrate with an elongate posteroventral process, pectoral propterygium fused with first pectoral ray, and mobile premaxilla) and 12 homoplastic features. Nevertheless, the presence of a mobile premaxilla and pectoral propterygium fused to the first pectoral ray become homoplastic characters when the Triassic neopterygian $\nmid$ Prohalecites is added to the phylogenetic analysis (see Arratia 1999).

Node B stands at the branching of $\dagger$ Leptolepis coryphaenoides and more advanced teleosts. Four uniquely derived characters (supraoccipital bone extending forward in roof of the otic region, cycloid scales present, urohyal formed as 
an unpaired tendon-bone, and hyoidean artery piercing one or both hypohyals) and 23 homoplasies support this node. For additional information see Arratia (1999: 323).

Tharsis and more advanced teleosts stand at Node C. This node is supported by four uniquely derived characters (sutures between all cartilage bones in braincase retained throughout life, ossified aortic canal absent, canals for occipital arteries in basioccipital bone absent, and autocentrum with cavities for adipose tissue) and nine homoplasies.

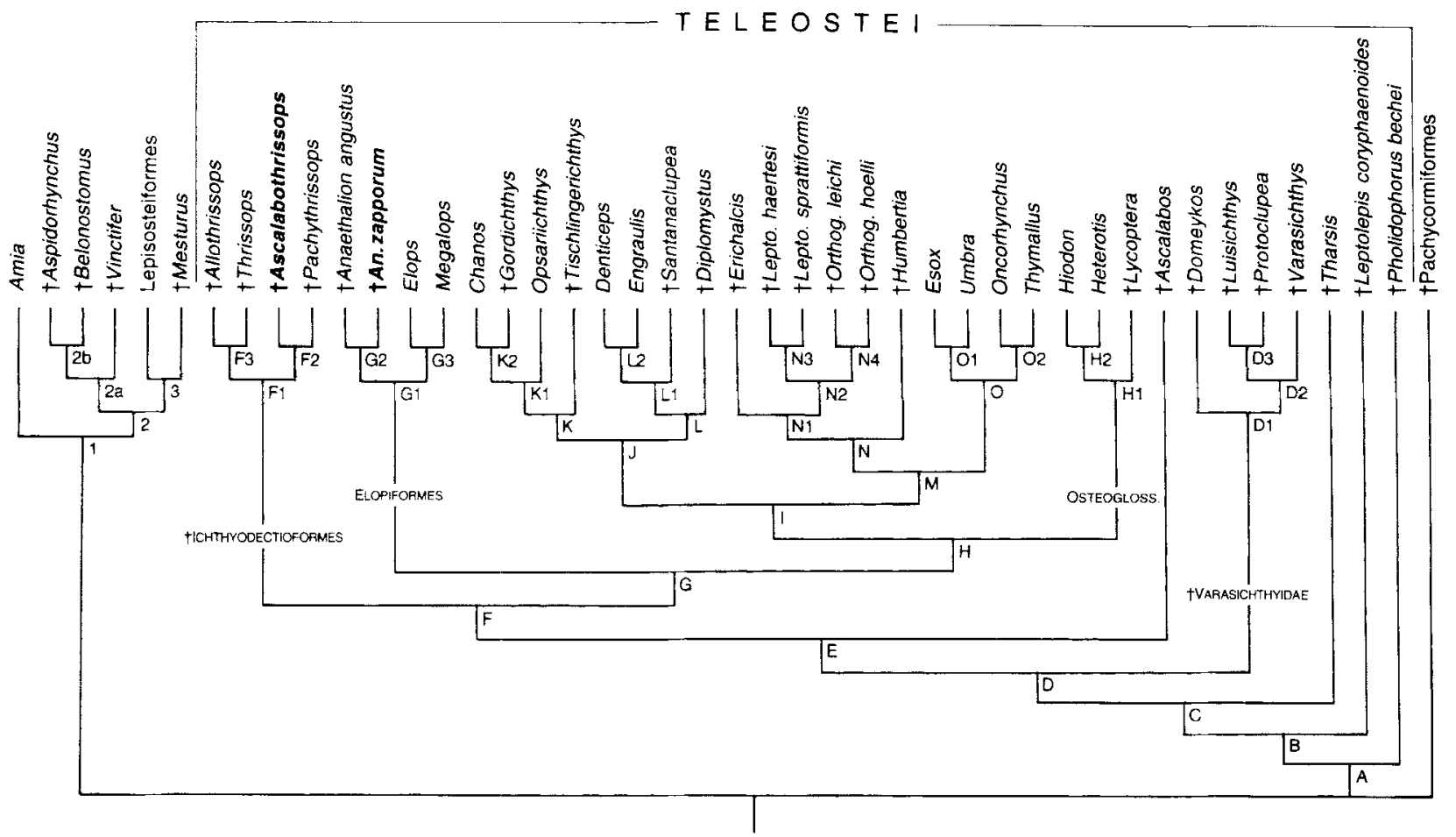

Fig. 21. Hypothesis of phylogenetic relationships of some fossil (i) basal teleosts based on one single tree at 666 evolutionary steps (using 191 characters: for characters and their coding see Table 1 and Appendix 1). Amia calva, $\dagger$ A. pattersoni, aspidorhynchiforms ( $\uparrow$ Aspidorhynchus, $\dagger$ Belonostomus, and $\dagger$ Vinctifer), lepisosteiforms (Lepisosteus and $\nmid$ Obaichthys), pachycormiforms (†Hypsocormus and $\dagger$ Pachycormus). and $\dagger$ Mesturus. are used as outgroup. Characters interpreted as uniquely derived are indicated with an asterisk (*). Synapomorphies supporting nodes are:

Non-teleostean nodes: Node 1: 149[1]. and 167[0]. Node 2: 24[0]. 46[1]. 56[1]. 90[2], 95[1], 151[1], 186[1]*. Node 2a: 3[2], 7[1], 32[1], 117[4] . 119[4], 121[1], 123[3], 126[1] . 128[1] . 142[3], 165[2] . 166[1], 179[2], 183[1]*, 184[1]*, 185[1] , and 187[1]*. Node bb: 46[2], 107[2], 109[1] 110[1]. 111[1]. 118[1], and 149[0]. Node 3: 36[2], 47[3], and 156[1]*. [Lepisosteus $+\dagger$ Obaichthys]: 5[1], 15[2], 16[2]. 45[2]. 70[1]*. 114[1] *. 177[2]. and 178[0]. [Amia calva $+\uparrow$ A. pattersoni]: 31[1], 32[2], 112[1] ${ }^{*}, 117[1], 137[1], 146[1]$, 150[1], 161[0]. 162[0]. 163[1]*. 164[1]. 165[1]. and 178[0]. [†Pachycormuts $+\dagger$ Hypsocormus]: 8[1], 32[3]. 110[2]*, 111[2], 115[3], $116[2], 118[1], 126[2], 122[2], 130[2], 142[1], 147[2], 150[1], 166[2], 168[2], 190[1] *$. and 191[1]*

Teleostean nodes: Node A (Teleostei): 49[1]. 55[1]*. 92[1]*. 107[0], 121[1]. 123[1], 125[1], 138[1], 145[1], 166[1], 169[1], 174[2]*, 175[1], 177[1]. and 179[1]. Node B: 4[2]*, 15[1], 16[1], 23[1], 47[1], 50[1], 51[1], 71[1], 83[1], 100[1], 101[1], 117[1], $119[1], 120[1], 124[1] .128[1] .136[1] .141[1] .142[2] .152[1] * .167[1] .168[1], 170[1] .171[1] *, 172[1]^{*}, 176[1]$, and 182[1]. Node C: $6[1]^{*}, 12[1]^{*} .13[1]^{*} .14[2] .20[1] .31[1] .32[1] .72[2] .73[2]^{*} .74[2] .85[1] .137[1]$. and 165[2]. Node D: 21[1], 130[1], and 140[1]. Node D1 (iVarasichthyidae): 65[1]. 66[1]*. 88[1], 90[1], 93[1]. 94[1]. 141[0], 142[1], 153[1]*, 154[1], and 165[1]. Node D2: 101[2] and 111[1]. Node D3: 100[2]. 119[3], and 125[2]. Node E: 84[1]. Node F: 26[1], 51[0], 58[1], 85[2], and 139[1]. Node F1: $3[2], 91[1]^{*}, 95[1]$, and 109[1]. Node F2: 106[1]. 124[2]. 137[0]. 140[0]. and 147[1]. Node F3: 1[1]*, 2[1], 24[2], 85[0], 98[1]*, 100[2]. 101[2]. and 122|1]*. Node G: 57[1]. 60[1]\%. 119[3]. 123[3]. 124[2]. 144[1]. 145[0], 173[1], 180[1]*, and 181[1]. Node G1: 25[1]* 41[1]* 113[1]*, 125[2]. 136[2], 154[1], and 155[1]*. Node G2: 109[1]. 110[1], and 137[0]. Node G3: 15[2], 23[0], 59[1]*, 61[1]*, 65[1], 84[0], 87[1], 90[1], 94[2], 97[1]. 102[1]. 120[2], 126[1]. and 165[1]. Node H: 24[2], 52[1]*, 61[2]*, 106[1], 126[1], 136[3], and 146[1]. Node H1: 10[2]. 29[1]*. 32[2]. 78[1]. 84[0]. 85[0]. 95[1]. 107[1], 117[3], 141[2], 142[3], 143[1], 149[1], 159[1]*, 165[1]. and 179[0]. Node H2: 30[1]*. 46[1]. 49[0]. 56[1]. 69[1]*. 147[1]. and 160[1]. Node I: 10[1], 48[1], 49[2], 56[1], 57[2], 58[0], 62[1] * 63[1], 109[1], 111[1], 120[2] . 125[3]. and 147[1]. Node J: 28[1]*, 36[1], 75[1], and 128[0]. Node K: 5[1], 46[1], 76[1]* .77[1]. 109[2] . 110[2]. 111[2]. 115[2]. 129[1]. and 131[1]. Node K1: 42[1]. 45[1]. 94[3], 117[3], 119[4], 120[3], 121[3], and 154[1]. Node K2: 3[1], 35[1], 37[1]*. 43[1]*. 44[1]*, 47[3], 50[0], 51[1], 64[1], 68[1]*, 75[0], 79[1]*, 144[0], and 179[0]. Node L: 18[1]*. 19[1]. 124[3]*. 127[1]* and 148[1]. Node L1: 17[1]*. 27[1], 47[0], 120[3], and 121[3]. Node L2: 32[2], 71[2], 77[1], 87[1], 89[1]. 116[1]. 117[2]. 119[4]. and 149[1]. Node M: 101[2]. 110[1]. and 132[1]*. Node N: 34[1]*, 121[2], 125[2], and 136[2]. Node N1: 35[1], 50[0]. 96[1]. 99[1]. 103[1]. 120[3], and 130[0]. Node N2: 33[1]* and 38[1]*. Node N3: 10[0], 56[0], 72[3], 101[1], 109[0], 110[0]. 111[0]. 139[0]. and 145[1]. Node N4: 8[1], 9[1], 26[0]. 32[0], 47[2], 67[1], 100[2], and 105[1]. Node O: 36[1], 67[1]. 82[1]*. 107[2]. 108[1]. 115[1]. $116[1] .119[4], 120[4] .121[3]$. and 149[1]. Node O1: 2[1], 22[1]*, 23[2], 45[1], 47[2], 53[1], $54[1] .77[1], 78[1] .83[0], 84[0] .95[1], 117[2] .124[3]$. and 181[0]. Node O2: 8[1], 64[1], 85[1], 94[2], 102[1], 135[1]*, 157[0], and $158[1]$; 
Table 1

Data matrix of Taxa Set representing 191 characters belonging to fossil $(\dagger)$ and extant taxa. 0, plesiomorphic state: $1-4$. apomorphic states; ?, unclear, owing the preservation of the specimens. An.: $\nmid$ Anaethalion; Leptolepis coryp.: $\nmid$ L. coryphaenoides; Lep.: †Leptolepides; Orth.: †Orthogonikleithrus; Phol.: $†$ Pholidophorus.

\begin{tabular}{|c|c|c|c|c|c|c|c|c|c|c|c|c|}
\hline & $1-5$ & & $6-10$ & $11-15$ & & $16-20$ & $21-25$ & $26-30$ & \multicolumn{2}{|c|}{$31-35$} & $36-40$ & $41-45$ \\
\hline 1. $\uparrow$ Allothrissops & $110 / 2$ & $2 ?$ & 10000 & $0 ? ? 2$ & $?$ & 10001 & 10120 & 10000 & 1 & 10001 & $? 00001$ & 00000 \\
\hline 2. Amia calva & $000 / 2$ & 00 & 00000 & 0000 & 0 & 00000 & 00010 & 00000 & 1 & 2000 & 00000 & 000000 \\
\hline 3. $†$ Amia pattersoni & 000 & 00 & 00000 & $0 ? ? 0$ & $?$ & 00000 & $? 0010$ & 00000 & 1 & 2000 & $? 0000$ & 00000 \\
\hline 4. + An. angustus & 000 & 20 & 10000 & $0 ? ? 2$ & $?$ & $? 000 ?$ & $? 0111$ & $? 0000$ & 1 & 1000 & $0000 ?$ & 10000 \\
\hline 5. †An. zapporum & 000 & $? 0$ & $1 ? 000$ & 0 ??? & $?$ & $? 000 ?$ & $? 01111$ & $? 0000$ & 1 & 1000 & $? 0000$ & 10000 \\
\hline 6. Ascalabos & 000 & $2 ?$ & $1 ? 00 ?$ & $0 ? ? 2$ & $?$ & $? 0001$ & $? 01 ? 0$ & $? 0 ? 00$ & 1 & $? 0 ? ?$ & $? 0000$ & 00000 \\
\hline 7. $\dagger$ Ascalabothrissops & ? ? ? & $? ?$ & $1 ? 00 ?$ & $0 ? ? ?$ & $?$ & $? 000 ?$ & $? 01 ? 0$ & $? 0 ? 00$ & 1 & $? ? ? 1$ & $? 000 ?$ & 00000 \\
\hline 8. $†$ Aspidorhynchus & $? 02$ & $0 ?$ & 01000 & $0 ? ? ?$ & 0 & $? 0000$ & $? 0000$ & 00000 & 0 & $100 ?$ & $? 0000$ & 00000 \\
\hline 9. $\nmid$ Belonostomus & 002 & $0 ?$ & $01 ? 00$ & $0 ? ? ?$ & 0 & 20000 & 00000 & 000000 & 0 & 1000 & $? 0000$ & 00000 \\
\hline 10. Chanos & 001 & 21 & 10001 & 0112 & 1 & 10001 & 10120 & 10100 & 1 & 1001 & 110 & 011111 \\
\hline 11. Denticeps & 000 & 20 & 10101 & 0112 & 1 & 01101 & 10120 & 11100 & 1 & 2000 & & 00000 \\
\hline 12. †Diplomystus & 000 & $1 ?$ & 10001 & $0 ? ? 2$ & $?$ & $1011 ?$ & $? 0120$ & $10 ? 00$ & 1 & $? 00 ?$ & $? 00$ & 00 \\
\hline 13. †Domeykos & 000 & $? ?$ & $1 ? 001$ & $0 ? ? 2$ & $?$ & $? 0001$ & $? 01 ? 0$ & $? 00 ? ?$ & 1 & ???? & & $? 0$ \\
\hline 14. Engraulis & 000 & 20 & $1 ? 001$ & 0112 & 1 & 11111 & 10020 & 11100 & 1 & & & 00 \\
\hline 15. Elops & 000 & 20 & 10000 & 01112 & 2 & 10001 & 10011 & 10000 & 1 & & & 00 \\
\hline 16. †Erichalcis & 000 & $? ?$ & 10001 & $? ? ? 2$ & $?$ & $? 000 ?$ & $? 01 ? 0$ & 10000 & 1 & & & 00 \\
\hline 17. Esox & 010 & 20 & 10101 & 0112 & 1 & 10001 & 11220 & 10000 & 1 & $10 ? 0$ & & 01 \\
\hline 18. †Gordichthys & 001 & $2 ?$ & $? ? 0$ & ???? & $?$ & $? 000 ?$ & $? 011 \%$ & $10 ? 00$ & 1 & & & 11 \\
\hline 19. Hiodon & 000 & 20 & 10002 & 0112 & 1 & 10001 & 10120 & 10011 & 1 & 20 & & 00 \\
\hline 20. Heterotis & $? 00$ & 21 & 100 & 0112 & $?$ & 00001 & $101 ? 0$ & 10011 & 0 & & & 00 \\
\hline 21. †Humbertia & 000 & 20 & $1 ? 001$ & 0112 & $?$ & 10001 & 10120 & 000 & 1 & 10 & & 00 \\
\hline 22. †Hypsocormus & 000 & 00 & $0011 ?$ & $0 ? ? 0$ & 0 & 00000 & $000 ? 0$ & $? 0000$ & 0 & & & 00 \\
\hline 23. †Leptolepis coryp. & 000 & 20 & 00000 & 00001 & 1 & 00 & 00110 & 000 & 0 & 00 & & 00 \\
\hline 24. Lepisosteus & 000 & 01 & 00000 & $0 ? 00$ & 2 & 20000 & 00000 & 000 & 0 & & & \\
\hline 25. †Lep. haertesi & 000 & $? ?$ & 10110 & $0 ? ? 2$ & $?$ & $? 000 ?$ & $? 0120$ & 000 & 1 & $011 ?$ & $? 01$ & 00 \\
\hline 26. $\dagger$ Lep. spratiformis & 000 & 20 & & 0112 & $?$ & & $? 0120$ & & 1 & & & 00 \\
\hline 27. †Luisichthys & $? 00$ & $2 ?$ & 11000 & 0112 & $?$ & $? 0 ? 01$ & $1 ? 1 ? 0$ & 10000 & $?$ & ???? & & 00 \\
\hline 28. + Lycoptera & 000 & $? 0$ & 10002 & $0 ? ? 2$ & $?$ & $? 000 ?$ & $? 0120$ & 00010 & 1 & & & 00 \\
\hline 29. Megalops & 000 & 20 & 10000 & 0112 & 2 & 10001 & 10011 & 10000 & 1 & 10 & 000 & 00 \\
\hline 30. $\dagger$ Mesturus & 000 & $? 0$ & $0 ? 001$ & $1 ? ? ?$ & 1 & $? 0000$ & 00100 & $0100 ?$ & 1 & 2001 & $2 ? ? 0 ?$ & 9000 \\
\hline 31. †Obaichthys & 000 & 01 & $0 ? 010$ & $0 ? ? ?$ & 2 & $2000 ?$ & $00 ? 00$ & ? $0 ? 0 ?$ & 0 & $000 ?$ & 20000 & 02 \\
\hline 32. Oncorhynchus & 000 & 20 & 10101 & 0112 & 1 & 10001 & 10120 & 10000 & 1 & 1000 & 10000 & 00000 \\
\hline 33. Opsariichthys & 000 & 21 & 11101 & 0112 & $?$ & 10001 & 10100 & 00100 & 1 & 1000 & 10000 & 01001 \\
\hline 34. †Orth. leichi & 000 & $? ?$ & $1 ? 111$ & $0 ? ? 2$ & $?$ & $? 000 ?$ & $? 01 ? 0$ & 10000 & 1 & $? ? ? 0$ & $? 0100$ & 00000 \\
\hline 35. †Orth. hoelli & 000 & 20 & $1 ? 111$ & $0 ? ? 2$ & $?$ & $? 000 ?$ & $? 01 ? 0$ & 10000 & 1 & $11 ? 1$ & $? 0100$ & 01001 \\
\hline 36. †Pachycormus & 000 & 00 & 00100 & $0 ? ? 0$ & 0 & 00000 & $? 0010$ & 00000 & 0 & $300 ?$ & $? 0000$ & 00000 \\
\hline 37. †Pachythrissops & $? ? 2$ & $? ?$ & $1 ? 000$ & $0 ? ? 2$ & $?$ & ?0??? & $? 01 ? 0$ & $? 0000$ & 1 & $10 ? 0$ & $? 000 ?$ & 00000 \\
\hline 38. †Phol bechei & 000 & $? ?$ & 00000 & 0000 & 0 & 00000 & 00010 & 00000 & 0 & 0000 & $? 00000$ & 00000 \\
\hline 39. 1 Protoclupea & $? ? 0$ & $2 ?$ & $1000 ?$ & $0 ? ? 2$ & $?$ & $? 0 ? 0 ?$ & $? 011 ?$ & $0000 ?$ & $?$ & $? 00 ?$ & $? 0000$ & 00000 \\
\hline 40. †Santanaclupea & 000 & $? ?$ & 10001 & $0 ? ? 2$ & $?$ & $? 1110$ & $00 ? ? ?$ & $1110 ?$ & 1 & $1 ? ? ?$ & $? 001 ?$ & 00000 \\
\hline 41. †Tharsis & 000 & 20 & 10001 & $01111 / 2$ & 1 & 1000001 & 00110 & 10000 & 1 & 1000 & 00001 & 00000 \\
\hline 42. †Thrissops & 112 & $? ?$ & $1 ? 00 ?$ & $0 ? ? 2$ & 1 & $1000 ?$ & $? 0120$ & 10000 & $0 / 1$ & $100 ?$ & $? 000 ?$ & 00000 \\
\hline 43. †Thymallus & 000 & 20 & $1 ? 101$ & 0112 & 1 & 100001 & 10120 & 10000 & 1 & 1000 & 10000 & 00000 \\
\hline 44. †Tischlingerichthys & $00 ?$ & $? 1$ & $1 ? 000$ & 0112 & $?$ & $? 00001$ & $1 ? 1 ? 0$ & ? 0 ? 0 ? & 1 & $? 000$ & $? 000 ?$ & 00000 \\
\hline 45. Umbra & 010 & $2 ?$ & 100001 & 0112 & 1 & 10001 & 11220 & 10000 & 1 & $10 ? 0$ & 10000 & $0 ? 001$ \\
\hline 46. †Varasichthys & 000 & 20 & 10001 & 1112 & $?$ & $? 0001$ & 10110 & 00000 & 0 & $100 ?$ & $? 0000$ & 00000 \\
\hline 47. †Vinctifer & 002 & $? 0$ & 01001 & $0 ? 02$ & 0 & $? 0000$ & 00000 & 00000 & 0 & $100 ?$ & $? 0000$ & 00000 \\
\hline
\end{tabular}

The Late Jurassic family †Varasichthyidae and more advanced teleosts stand at Node D. This node is supported by three homoplastic characters (see Fig. 21: Nodes D1-D3 for characters supporting the relationships among members of the family $\nmid$ Varasichthyidae).

$\dagger$ Ascalabos and more advanced teleosts stand at Node E. This node is supported by one homoplastic feature.

Node F corresponds to the branching of the ichthyodectiforms and more advanced teleosts. This node is supported by five homoplasies. The ichthyodectiforms (Node F1) are supported by one uniquely derived character (coracoid bone enlarged ventrally meeting its fellow in a midventral coracoid symphysis) and three homoplasies. Although the information on the coracoid is missing in $\dagger$ Ascalabothrissops $\mathrm{n}$. gen., due to incomplete preservation, the parsimony analysis suggests that the new fish shares this feature with other ichthyodectiforms. The sister-group relationship [ $\nmid$ Ascalabothrissops $+\nmid$ Pachythrissops] (Node F2) is supported by five homoplasies, whereas the sister-group [ $†$ Allothrissops + $\nmid$ Thrissops] is supported by three uniquely derived features and five homoplasies. 


\begin{tabular}{|c|c|c|c|c|c|c|c|c|c|c|}
\hline & $46-50$ & & $51-55$ & $56-60$ & $61-65$ & $66-70$ & $71-75$ & $76-80$ & $81-85$ & $86-90$ \\
\hline 1. †Allothrissops & 01 & 011 & 00001 & ? ? 1 ? ? & ? ? 101 & 00000 & 12220 & $00 ? 01$ & 10100 & 000000 \\
\hline 2. Amia calva & 00 & 000 & 00000 & 00000 & 00000 & 00000 & $? 0000$ & 00001 & $000 ? 0$ & 00000 \\
\hline 3. †'Amia pattersoni & 00 & 000 & 00000 & $00 ? ? !$ & $\because 3000$ & 00000 & $? 0000$ & $0 ? ? 01$ & ??0?0 & $00 ? 0 ?$ \\
\hline 4. †An. angustus & 01 & $? ? 1$ & 00001 & $0 ? 1 ? ?$ & $? ? ? 00$ & 00000 & 12220 & $00 ? 01$ & 10112 & $10 ? 0 ?$ \\
\hline 5. † An. zapporum & 01 & $0 ? 1$ & 00001 & 0???? & $? ? ? 00$ & $0 ? 000$ & 12220 & $00 ? 01$ & 10112 & $0010 ?$ \\
\hline 6. $\dagger$ Ascalabos & (0) 1 & 0 ? & 10001 & $1 ? "$ & $? ? ? 00$ & & 122 & 000 & & 00000 \\
\hline 7. Ascalabothrissops & 01 & $? ? ?$ & $0: ?: 001$ & 0???? & $? ? ? 00$ & 00000 & $13 ? 20$ & $? 0 ? 01$ & & \\
\hline 8. $\dagger$ Aspidorhynchus & 20 & ?() 0 & (0) 00000 & $10 ? ? ?$ & $\because ? ? 00$ & 000000 & 00000 & (0) $0 ? 01$ & $? ? 000$ & () 000 ? \\
\hline 9. †Belonesfomus & 20 & $\because ? 0$ & 00000 & $10 ? ? !$ & 39900 & 00000 & & $00 ? 01$ & & $00 ? 02$ \\
\hline 10. Chanos & 13 & 120 & 11001 & 12001 & 21110 & 00100 & 12220 & $\begin{array}{llllllll}1 & 1 & 0 & 1 & 1\end{array}$ & & 11000 \\
\hline 11. Denticeps & 12 & 121 & 01001 & 12001 & 21100 & 00000 & $22 ? 21$ & 001 & & 010 \\
\hline 12. †Diplomystus & 01 & $1 ? 1$ & $? 1001$ & $1 ? ! ? !$ & $? ? ? 00$ & 000 & 12221 & $00 ? ? 01$ & & $0 ? 0$ \\
\hline 13. †Domeykos & 01 & $? 11$ & $? 000 ?$ & ? ? ? ? ? & ??"?01 & $100 ? 0$ & 12220 & 000001 & 101 & 101 \\
\hline 14. Engraulis & 00 & 121 & 011001 & 12001 & 21100 & 000 & 22221 & 011001 & 0112 & 1010 \\
\hline 15. Elops & 00 & () 31 & & 0111111 & & & 12220 & & 102 & \\
\hline 16. 化ichalcis & 01 & 120 & 01001 & $1 ? ? ? ?$ & ???00 & & 12220 & $01 ? 01$ & & 00000 \\
\hline 17. Esox & 02 & 121 & $\begin{array}{llllllllll}0 & 1 & 1 & 1 & 1\end{array}$ & 12101 & 21100 & 000 & 12220 & & & 01000 \\
\hline 18. †Gordichthys & 13 & 120 & $1 ? 001$ & $1 ? ? ? ?$ & 10 & & & & & $? 00$ \\
\hline 19. Hiodon & 11 & 001 & 010001 & 1111001 & 20000 & 0010 & 12220 & 001 & 0 & 000000 \\
\hline 20. Heterotis & 12 & $00 !$ & & $1 ? 102$ & & & 21 & & & \\
\hline 21. $\dagger$ Humbertia & $0 ?$ & 121 & 01001 & $1 ? ? ? ?$ & $?: 100$ & 00000 & $12 ? 20$ & $00 ?$ & & $00 ? 00$ \\
\hline 22. $\nmid$ Hypsocormus & $? 0$ & $2 ? 0$ & $0 ? 000$ & 0??"?"? & ?"? ?.00 0 & $? ? 000$ & 00000 & ??? & 0 & 00??? \\
\hline 23. $\nmid$ Leptolepis coryp. & 01 & $? 11$ & 10001 & $0 ?: ? ?$ & ?? $? 000$ & 0000000 & & 000001 & & 100 \\
\hline 24. Lepisosteus & 13 & 000 & 00000 & 10000 & 00000 & 00001 & $? 0000$ & 00000 & 0 & $? 02$ \\
\hline 25. $\frac{\dagger}{\dagger}$ ep. hatertesi & 02 & ??0 & $? 1001$ & ???? & $? 00$ & 01000 & ?? ? 0 & $? ? 1$ & $? 112$ & $? 00$ \\
\hline 26. 广Lep sprattiformis & 03 & 120 & $0 ? 001$ & $0 ? ? ? ?$ & $? ? 200$ & 00000 & $13 ? 10$ & $00 ? 01$ & 0111 & 00000 \\
\hline 27. †Luisichtinys & () 1 & $? ?$ & $? ? 001$ & 0???? & ???0? & 10000 & 12220 & $00 ? 01$ & $1 ? 1 ? 1$ & $00 ? 01$ \\
\hline 28. †Lycoptera & (1) 1 & $0 ? 1$ & 01001 & 0???? & ???:00 & 00000 & $12 ? 20$ & 00101 & 10100 & 00000 \\
\hline 29. Megalops & 01 & 011 & 000001 & $0 \begin{array}{llllllllll}0 & 1 & 1 & 1 & 1\end{array}$ & 001 & 000000 & 12220 & 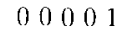 & 02 & 01001 \\
\hline 30. $†$ Mesturus & $12 / 3$ & $2 ? 0$ & $0 ? ? ? ?$ & 1???? & ??"?00 & $0 ? 000$ & 000000 & ? 01 & 000 & $00 ? 02$ \\
\hline 31. TObaichthys & 13 & $? ? ?$ & ???0? & $1 ?: ?$ & $? ? ? 00$ & $0 ? 0 ? 1$ & $? 000 ?$ & ? ? ??? & ????? & $? 0 ? ? 2$ \\
\hline 32. Oncorhunchus & 0.3 & 121 & 01001 & 12001 & 21110 & 010000 & 12220 & 00001 & 111111 & 000 \\
\hline 33. Opsarichthys & 12 & 121 & 01001 & $11 ? 01$ & 21100 & 00000 & $? 3 ? 21$ & 11101 & $102 ? 2$ & 01000 \\
\hline 34. †Orth. leichi & 01 & $? ? 0$ & $? 1001$ & 1???? & $? ? ? 00$ & 01000 & 12220 & $00 ? 01$ & 10111 & 00000 \\
\hline 35. †Orth. hoelli & 01 & 120 & 01010001 & ??" & $? ? 100$ & 010000 & $12 ? 20$ & $? 01$ & $1011 ?$ & $00 ? 00$ \\
\hline 36. †Pachromus & 20 & $? 0$ & $? 000$ & (0?:0?? & $? ? ? 00$ & 0000000 & 0000000 & $00 ? 01$ & $? ? 000$ & $00 ? 0 ?$ \\
\hline 37. Pachythissops & 01 & $0 ? 1$ & 00001 & () ???? & $? ? ? ? 0$ & 000000 & 12220 & $00 ? ? 01$ & $1 ? 112$ & $00 ? ? ?$ \\
\hline 38. $\nmid$ Phol bechei & (0) 0 & $? 10$ & 000001 & 0 ?? ?? & ?'? ? 00 & 00000 & 00000 & $00 ? 01$ & $? ? 0000$ & $00 ? 0 ?$ \\
\hline 39. †Protoclupe & 01 & $? 11$ & 10001 & "?"? ??"? & $? ? ? 01$ & $100 ? 0$ & 12220 & $00 ? ? 1$ & $1 ? 1 ? ?$ & $? 0101$ \\
\hline 40. $\stackrel{\dagger}{\dagger}$ Santanaclipea & 00 & $? ? 1$ & 01001 & $1 ? ? ? ?$ & $? ? ? 00$ & $000 ? 0$ & $? 22 ? 0$ & $? 0 ? 01$ & $1 ? 1 ? ?$ & $? 0 ? ? 0$ \\
\hline 41. †Tharsis & 01 & $? 11$ & 10001 & ()???? & $? ? ? 00$ & 00000 & 12220 & 000001 & 10101 & 00000 \\
\hline 42. †Thrissops & 01 & $? ? 1$ & $? ? 001$ & ?"??!"? & $? ? ? 00$ & 000000 & 12220 & $\begin{array}{lllllllllllll}0 & 0 & ? & 0 & 1\end{array}$ & $1 ? 110$ & $00 ? 00$ \\
\hline 43. ¡Thymallus & 01 & 121 & 010001 & 12001 & 21110 & 01000 & 12220 & $\begin{array}{llllllllllllllll}0 & 0 & 0 & 0 & 1\end{array}$ & $\begin{array}{lllll}1 & 1 & 1 & 1 & 1\end{array}$ & 000000 \\
\hline 44. †Tischlingerichthys & 11 & $? ? 0$ & $0 ? 00 ?$ & ()???? & ???? & $? ? 0 ? 0$ & 12221 & $11 ? ? 1$ & $101 ? 1$ & $00 ? 00$ \\
\hline 45. Umbra & 12 & 120 & 011111 & 12001 & 21100 & 01000 & 12221 & 01101 & 11002 & $0 ? ? 00$ \\
\hline 46. †Varasichthys & 01 & $? 20$ & 10001 & 0???? ? & ???01 & 10000 & 12220 & $00 ? 01$ & $1 ? 1 ? 1$ & 0001111 \\
\hline 47. †Vinctifer & 10 & $? 00$ & $0 ? 000$ & $10 ? ? ?$ & $? ? ? 00$ & 00000 & 000000 & $00 ? 01$ & ?? 000 & 00002 \\
\hline
\end{tabular}

Node $\mathrm{G}$ corresponds to the branching of the elopomorphs and more advanced teleosts. This node is supported by two uniquely derived features (pharyngobranchials as three ossified elements and a cartilaginous one bearing toothplate[s] and craniotemporal muscle present) and eight homoplasies. The sister-group relationship [ $\nmid$ Anaethalion angustus $+\nmid A$. zapportum] stands at Node G2 and is supported by three homoplasies, whereas the sister-group relationship [Elops + Megalops] stands at Node G3 and is supported by two uniquely derived features (branchial spiracle present and pharyngobranchial 1 with a bony. broad base articulating with epibranchial 1 and bearing a short dorsal process) and 12 homoplasies.

For characters supporting Nodes $\mathrm{H}$ to $\mathrm{O}$ see explanation of Figure 21.

The results of the phylogenetic analysis confirm my preliminary taxonomic assignment that $\dagger$ Ascalabothrissops voelkli is an ichthyodectiform and that $\nmid$ Anaethalion zapporum is an elopomorph.

Apparently, there is no doubt that $\dagger$ Ascalabothrissops and $\dagger$ Pachythrissops belong in the ichthyodectifoms. However, we should keep in mind that the information on both genera is incomplete due to poor preservation. Conse- 


\begin{tabular}{|c|c|c|c|c|c|c|c|c|c|c|c|c|c|c|c|c|}
\hline \multirow[b]{2}{*}{ 1. $\dagger$ Allothrissops } & \multirow{2}{*}{$\frac{91-95}{11001}$} & \multirow{2}{*}{$\frac{96-100}{0 ? 102}$} & \multirow{2}{*}{$\frac{101-105}{20000}$} & \multicolumn{4}{|c|}{$106-110$} & $111-115$ & \multicolumn{2}{|c|}{$116-120$} & \multicolumn{2}{|l|}{$121-125$} & \multicolumn{2}{|l|}{$126-130$} & \multicolumn{2}{|c|}{$131-135$} \\
\hline & & & & 10 & 0 & 1 & 0 & 0000 & $? 1$ & 011 & 1111 & 1 & $00 ? 0$ & 1 & 0 & 0000 \\
\hline 2. Amia calva & 00000 & 00000 & 00000 & 11 & 0 & 0 & 0 & 1000 & 01 & 000 & 0000 & 0 & 0000 & 0 & 0 & 00 \\
\hline 3. $\uparrow$ Amia pattersoni & 00000 & 00000 & $0000 ?$ & $? ?$ & $?$ & $?$ & $?$ & 1000 & 01 & 000 & 0000. & 0 & 0000 & 0 & 0 & $0 ?$ \\
\hline 4. †An. angustus & $010 ? 0$ & 00001 & $? 0000$ & 00 & $?$ & 1 & 1 & 0100 & 01 & $03 ?$ & 1032 & 2 & 0010 & 1 & 0 & 0000 \\
\hline 5. †An. zapporum & $0 ? 000$ & 00001 & 10000 & $? 0$ & 0 & 1 & 1 & 0100 & 01 & $0 ? ?$ & $? ? ? 2$ & $?$ & ?? 10 & 1 & 0 & 00 \\
\hline 6. $\uparrow$ Ascalabos & 01000 & 01001 & 10000 & 00 & 0 & 0 & 0 & 0000 & 01 & 011 & $10 ? 1$ & 1 & 0010 & 1 & 0 & 00 \\
\hline 7. †Ascalabothrissops & & & 10000 & 10 & 0 & 1 & 0 & 0000 & 02 & $0 ? 1$ & 1012 & 1 & & 0 & 0 & \\
\hline 8. †Aspidorhynchus & 00001 & 0 & 00000 & $10 / 2$ & $0 / 1$ & 1 & 1 & 0000 & 04 & 14 & $1030 / 4$ & $?$ & $? 010$ & 0 & 0 & 0? \\
\hline 9. $\uparrow$ Belonostomus & $? 001$ & 00 & & 22 & 1 & 1 & 1 & 0000 & 04 & & $1030 / 4$ & $?$ & & 1 & 0 & \\
\hline 10. Chanos & 1130 & 01 & 110 & 12 & 0 & 2 & 2 & 02 & $? 3$ & 43 & & 3 & 91 & 1 & 1 & 10 \\
\hline 11. Denticeps & & & 100 & 10 & 0 & 1 & 0 & 300 & 12 & & & 3 & & 1 & 0 & 00 \\
\hline 12. $†$ Diplomystus & $? 000$ & 01 & 100 & 10 & 0 & 1 & 0 & 0000 & 01 & 032 & 33 & 3 & & 1 & 0 & 0 ? \\
\hline 13. + Domeykos & & & & 10 & 0 & 0 & 0 & $\begin{array}{llllll}0 & 0 & 0 & 0 & 0\end{array}$ & 01 & & & 1 & & 1 & 0 & \\
\hline 14. Engraulis & $? 0$ & 00 & 21 & 10 & 0 & $1 / 2$ & 1 & $1 / 20001$ & 12 & & & 3 & $0 / 1$ & 1 & $0 / 1$ & 10 \\
\hline 15. Elops & & & & 00 & 0 & 0 & 0 & 00100 & 01 & & & 2 & & 1 & 0 & \\
\hline 16. Erichalcis & 00 & $1 ?$ & 20 & $1 ?$ & 0 & 1 & 1 & 1 & $? 1$ & & & $?$ & & 0 & 0 & \\
\hline 17. Esox & & & & 12 & 1 & 1 & 1 & 1 & 12 & & & 3 & & 1 & 0 & \\
\hline 18. †Gordichthys & $0 ? ? ? 0$ & $?$ & $? 0$ & 10 & 0 & 0 & 0 & $?$ & $? 2$ & & & $?$ & & 1 & 0 & \\
\hline 19. Hiodon & & & & 11 & 0 & 0 & 0 & 0 & & & & 3 & & 1 & 0 & \\
\hline 20. Heterotis & $01 ? ? 1$ & 01 & 000 & 11 & 0 & 0 & 0 & 0 & $? 4$ & & & 0 & & 1 & 0 & 00 \\
\hline 21. $\dagger$ Humbertia & $010 ? 0$ & & & 02 & 1 & 1 & 1 & 1 & $? 1$ & & & 2 & & 1 & 0 & \\
\hline 22. $\uparrow$ Hypsocormus & 000 & 01 & 000 & $? 3$ & $?$ & $?$ & 2 & $? 3$ & 20 & & & 0 & & 2 & 0 & 00 \\
\hline 23. †Leptolepis coryp. & & & & 00 & 0 & 0 & 0 & 0 & 01 & & & 1 & & 0 & 0 & 00 \\
\hline 24. Lepisosteus & 01 & 00 & & 01 & 0 & 0 & 0 & 0 & 00 & & & 0 & & 0 & 0 & 00 \\
\hline 25. †Lep. haertesi & & & 10 & $? 0$ & 0 & 0 & 0 & 00 & 01 & & & 2 & & 0 & 0 & $0 ?$ \\
\hline 26. †Lep. sprattiformis & & & & 00 & 0 & 0 & 0 & 0 & 01 & & & 2 & & 0 & 0 & 00 \\
\hline 27. †uisichthys & $1 ? 0 ?$ & 2 & & 00 & 0 & 0 & 0 & 1 & $? 1$ & & & 2 & & 1 & 0 & $0 ?$ \\
\hline 28. $\uparrow$ Lycoptera & $? ? ? 1$ & & & 11 & 0 & 0 & 0 & 0 & 03 & & & 1 & & 1 & 0 & 00 \\
\hline 29. Megalops & 1.? 20 & & & 00 & 0 & 0 & 0 & 0 & $? 1$ & & & 2 & & 1 & 0 & 00 \\
\hline 30. †Mesturus & 01 & & 00 & $? ?$ & $?$ & $?$ & $?$ & $? ?$ & $? ?$ & ? ? & ???? & $?$ & $? ?$ & $?$ & 0 & $0 ?$ \\
\hline 31. †Obaichthys & ??? 1 & ????? & ????? & $? ?$ & $?$ & $?$ & $?$ & $1 ?$ & $? ?$ & $? ? 0$ & ???? & $?$ & $0 ?$ & $?$ & $?$ & ? ? \\
\hline 32. Oncorhynchus & 1020 & & & 12 & 1 & 1 & 1 & 1 & 11 & & & 3 & & 1 & 0 & 01 \\
\hline 33. Opsariichthys & 1030 & 01 & 01000 & 10 & 0 & 2 & 2 & 2 & $? 3$ & 043 & 33 & 3 & 01 & 1 & 1 & 10 \\
\hline 34. †Orth. leichi & & 10012 & $2 ? 101$ & 10 & 0 & 1 & 1 & ? & $? 1$ & & & 2 & & $0 / 1$ & 0 & 00 \\
\hline 35. $\frac{1}{\dagger}$ Orth. hoelli & $? ? ? 0$ & 10012 & 20101 & 11 & 0 & 1 & 1 & 00 & $? 1$ & 044 & 33 & 2 & & 0 & 0 & 00 \\
\hline 36. †Pachycormus & & & & $? 1$ & 0 & 2 & 2 & 3 & 20 & 100 & 0000 & 0 & & 2 & 0 & 00 \\
\hline 37. †Pachythrissops & 1001 & 010001 & 20000 & 11 & 0 & 1 & 0 & 0000 & $? 1 / 2$ & 2021 & 1012 & 1 & 10 & 1 & 0 & 00 \\
\hline 38. †Phol bechei & 1000 & & 00000 & 00 & 0 & 0 & 0 & 00 & 00 & $0 ? ?$ & 1014 & 1 & & 0 & 0 & \\
\hline 39. †Protoclupea & $0 ? 110$ & 00002 & 20000 & 00 & 0 & $?$ & 0 & $000 ?$ & $? 1$ & 031 & $? 011$ & 2 & $? 0$ & 1 & 0 & 00 \\
\hline 40. †Santanaclupea & ????0 & 00001 & $1 ? 000$ & 10 & 0 & 1 & 1 & $00 ? 0$ & 0 ? & $0 ? 3$ & 3033 & 3 & $? 0$ & 1 & 0 & 00 \\
\hline 41. †Tharsis & 01000 & 00002 & 21000 & 00 & 0 & 0 & 0 & 00 & 01 & 011 & 2021 & 1 & 0010 & 0 & 0 & 00 \\
\hline 42. †Thrissops & 110001 & 00102 & 20000 & 00 & 0 & $?$ & $?$ & $000 ?$ & 01 & 011 & 2111 & 1 & $00 ? 0$ & 1 & 0 & 0000 \\
\hline 43. TThymallus & 01020 & 00002 & 21000 & 02 & 1 & 1 & 1 & 0001 & 11 & 044 & 3032 & 3 & 1010 & 1 & 0 & 1001 \\
\hline 44. $†$ Tischlingerichthys & $? ? 0 ? 0$ & 000001 & 20000 & 00 & 0 & 2 & 2 & 0002 & $? 1$ & 032 & 1032 & 2 & 1001 & 1 & 1 & $00 ? 0$ \\
\hline 45. Umbra & $01 ? ? 1$ & 00001 & 20000 & 12 & 1 & 1 & 1 & $000 ?$ & 12 & 044 & 3033 & 3 & 1010 & 1 & 0 & 1000 \\
\hline 46. †Varasichthys & 01110 & 010001 & & $? 1$ & 0 & 1 & 0 & 0000 & $? 3$ & 011 & & 1 & & 1 & 0 & $000 ?$ \\
\hline 47. †Vinctifer & 000001 & 00000 & 00000 & 01 & 0 & 0 & 0 & $0 \quad 00000$ & 04 & 041 & $103 ?$ & 2 & 1010 & 0 & 0 & 0000 \\
\hline
\end{tabular}

quently, the taxonomic position of $\nmid$ Pachythrissops (and now $\nmid$ Ascalabothrissops n. gen.) remains problematic because it is unclear whether they belong or not in the family Allothrissopidae as defined by Patterson \& Rosen (1977). Furthermore, both genera present generalized morphological patterns that makes their proper assignment among the ichthyodectiforms difficult. The current diagnosis of the genus †Pachythrissops already reflects this problem; it is based on a combination of features and no autapomorphy has been discovered (Arratia 1997). Until recently $\dagger$ Pachythrissops included three species, $\dagger P$. laevis (type species) from the upper Portlandian of Dorset, England, $\nmid P$. propterus from the Upper Jurassic of Bavaria, and $\dagger P$. vectensis from the Wealdien of Wight (England) and Bernissart (Belgium). The third species was recently removed from $\nmid$ Pachythrissops and reassigned to a new genus, $\uparrow$ Arratiaelops, that is included in the elopomorphs (Taverne 1999). The comparison between $\nmid$ Pachythrissops propterus and $\dagger$ Ascalabothrissops voelkli shows that the second species is based on autapomorphies and a combination of characters that differ from that of $\dagger$ Pachythrissops. The available information indicates that more specimens are needed to clarify the position of $\dagger$ Ascalabothrissops and $\dagger$ Pachythrissops within the ichthyodectiforms.

The phylogenetic position of $\dagger$ Anaethalion zapporum n. sp. is complicated because the genus is paraphyletic. In the first cladistic analysis the 


\begin{tabular}{|c|c|c|c|c|c|c|c|c|c|c|c|}
\hline & $136-140$ & $141-14.5$ & $146-150$ & $151-155$ & $156-160$ & $161-165$ & $166-17$ & & $171-175$ & \multicolumn{2}{|l|}{$176-180$} \\
\hline 1. †Altothrissops & 11101 & 12001 & 00000 & 01000 & $0 ? 00 ?$ & 11002 & 11 & 11 & $11 ? 21$ & 111 & 1 ? \\
\hline 2. Amia calva & $31 ? 01$ & $200 ? 0$ & 10011 & 00000 & 01000 & 00111. & $00 \quad 0$ & 00 & 00000 & 000 & 00 \\
\hline 3. †Amia pattersoni & $31 ? 0 ?$ & $? 00 ? 0$ & 10011 & $00000 ?$ & $0 ? 00 ?$ & 0001111 & $00 \quad 0$ & 00 & & $0 ? 0$ & 0? \\
\hline 4. †An angustus & 20110 & $1201 ?$ & 00000 & 01011 & $0 ? 00 ?$ & $1100 ?$ & $10 / 11$ & 11 & & $1 ? 1$ & $1 ?$ \\
\hline 5. †An. zapporum & $2011 ?$ & $1201 ?$ & 00000 & $010 ? ?$ & $0 ? 00 ?$ & $? 1002$ & $\begin{array}{lll}11 & 1\end{array}$ & $1 ?$ & & $1 ? ?$ & $1 ?$ \\
\hline 6. †Ascalabos & 11101 & 12001 & 00000 & $010 ? 0$ & $0 ? 00 ?$ & 110 & 111 & 11 & & $1 ? 1$ & $1 ?$ \\
\hline 7. †Ascalabothrissops & $? 0110$ & 12001 & 01000 & $010: 0$ & $0 ? 00 ?$ & $? 1002$ & 11 & $1 ?$ & & $1 ? 1$ & $1 ?$ \\
\hline 8. †Aspidorhynchus & $300 ? 0$ & 011000 & 01000 & $0000 ?$ & $0 ? 00 ?$ & 11002 & 11 & 00 & & 001 & $2 ?$ \\
\hline 9. $\dagger$ Belonostomus & $300 ? 0$ & $23 ? 00$ & $? 0000$ & $1000 ?$ & $0 ? 00 ?$ & & $1 ?$ & 00 & & 0 ?? & $2 ?$ \\
\hline 10. Chanos & 31111 & 12001 & 010 & 0) 10 & 01000 & 110 & 11 & 11 & & 111 & 01 \\
\hline 11. Denticeps & 31111 & 22010 & 101 & & & 110 & 11 & 11 & & 101 & 11 \\
\hline 12. $\dagger$ †iplomystus & 31111 & 12010 & 100 & & & $? 10$ & 11 & $1 ?$ & & $1 ? 1$ & $1 ?$ \\
\hline 13. †Domeykos & $? 1101$ & 010001 & $0110 ? 0$ & $0011111 \%$ & $0 ? 00 ?$ & 110 & 11 & 11 ? & & $1 ? 1$ & 1 ? \\
\hline 14. Engraulis & 011111 & $120 ! 0$ & 11110 & 01000 & $0 ? 000$ & 110 & 11 & $1 / 211$ & & 111 & ?? \\
\hline 15. Elops & 21111 & 12010 & 000000 & 0101011 & 010 & & 11 & 111 & & 111 & 11 \\
\hline 16. $\dagger$ Erichalcis & 211111 & 120 & $110 ? 0$ & $0 ? 0$ & $0 ? 0$ & & 11 & $1 ?$ & & $1 ? 1$ & $1 ?$ \\
\hline 17. Esox & 31111 & 120 & 10010 & 01000 & 01000 & 110 & 11 & 11 & 111 & 111 & 11 \\
\hline 18. †Gordichthys & 111 & & 100 & & $? 00 ?$ & 110 & 11 & 1 ? & & $1 ? ?$ & 0? \\
\hline 19. Hiodon & 31111 & 23110 & 110 & & 011011 & & 11 & $0 / 1111$ & & $110 / 10$ & 01 \\
\hline 20. Heserotis & 3111111 & 23110 & 11010 & $0 ? 0$ & $0 ? ? 01011$ & 110 & $1 ?$ & 110 & & 101 & 01 \\
\hline 21. †Humbertia & 21111 & 12010 & $? 1000$ & 010 & ()??0? & & 11 & 11 & & 111 & $1 ?$ \\
\hline 22. †Hypsocormus & 00000 & 01000 & 02001 & $0000 ?$ & $0 ? 00 ?$ & $1 ? 00 ?$ & 22 & 0 ? & ? & $? 0 ?$ & 0 ? \\
\hline 23. +Leptotepis corvp. & 10100 & 120 & 00 & & (3? & & 11 & 11 & & 111 & $1 ?$ \\
\hline 24. Lepisosteus & $30 ? 00$ & $20 ? ? 0$ & 00010 & 10000 & 10000 & 21000 & 00 & 00 & & 020 & 00 \\
\hline 25. †Lep. haertesi & 21101 & 12011 & 11000 & $0100 ?$ & $0 ? 00 ?$ & $1 ? 002$ & 11 & $1 ?$ & ??? & ??? & $1 ?$ \\
\hline 26. $\dagger$ Lep. sprattiformis & 21101 & 12001 & 10000 & 01010 & $0 ? 00 ?$ & 110 & 11 & 11 & 21 & $1 ? 1$ & 1 ? \\
\hline 27. †Luisichthys & $? 11$ & 010 & 00000 & $0111 ? ?$ & $0 ? 00 ?$ & 110 & 11 & $11 ?$ & 21 & $1 ? 1$ & $1 ?$ \\
\hline 28. †Lycoptera & 31111 & 23110 & 10010 & 01000 & $0 ? 01 ?$ & 11001 & 10 & $0 ! 111$ & $? ? 121$ & $1 ? 1$ & 0 ? \\
\hline 29. Megalops & 1111 & 12010 & 00000 & 010011 & 01000 & 11001 & 11 & 111 & 1121 & 111 & 11 \\
\hline 30. $†$ Mesturus & $? 1 ? 21$ & $010 ? ?$ & 00110 & 10000 & $1 ? 00 ?$ & $1 ? 01 ?$ & ?? & $? ?$ & ???? 1 & $0 ? 1$ & 0 ? \\
\hline 31. †Obaichthys & $? 0 ? 00$ & $? 0 ? ? ?$ & $? 00 ? 0$ & $10 ? ? ?$ & 1???? & $? ? 00 ?$ & $? 0$ & ? 0 ? & ????? & $? 20$ & ?? \\
\hline 32. Oncorhynchus & 31111 & 12010 & 11010 & 01000 & 00100 & 11002 & 10 & $0 / 1111$ & 21 & 111 & 11 \\
\hline 33. Opsariichthys & 31111 & 11010 & 01000 & 010010 & 010000 & 010 & 12 & 211 & 21 & $1 ? 1$ & 1 ? \\
\hline 34. $\nmid$ Orth. leichi & 1111 & 12010 & 11000 & $0100 ?$ & $0 ? 00 ?$ & $1 ? 00 ?$ & 11 & 11 & ???2? & ??? & $1 ?$ \\
\hline 35. †Orth hoelli & $11 ? 1$ & 12010 & 11000 & 02220 & $0 ? ? 0 ?$ & $1 ? 002$ & 11 & 11 & $11 ? 21$ & $1 ? ?$ & $1 ?$ \\
\hline 36. † Pachycormus & 30000 & 01000 & 02001 & $0000 ?$ & $0 ? 00 ?$ & $? 100 ?$ & 22 & 00 & ??? 10 & $00 ?$ & 0 ? \\
\hline 37. †Pachythrissops & 10110 & 12001 & 01000 & 010101 ? & $0 ? 00 ?$ & $1100 ?$ & 11 & 11 & ???2? & $1 ? ?$ & $1 ?$ \\
\hline 38. †Phol. bechei & 30100 & 000001 & 000000 & $0000 \% ?$ & $0 ? 00 ?$ & 11000 & 12 & 1 ? & ?? ? 21 & 011 & 1 ? \\
\hline 39. †Protoclupea & & & & & $0 ? 00 ?$ & $? 10$ & 11 & $1 ?$ & ???? 1 & $1 ? ?$ & $1 ?$ \\
\hline 40. $\nmid$ Santanaclupea & $? 11 ? ?$ & $1201 ?$ & $? 11 ? 0$ & $01 ? ?$ & $0 ? 00 ?$ & 11002 & $\begin{array}{lll}11 & 1\end{array}$ & 11 & $1 ? ? 21$ & $1 ? 1$ & $1 ?$ \\
\hline 41. †Tharsis & 11100 & $120 ? 1$ & 00000 & 01000 & $0 ? 00 ?$ & 11002 & $10 / 11$ & 11 & $11 ? 21$ & 111 & $1 ?$ \\
\hline 42. $\dagger$ Thrissops & 11111 & 12001 & 00000 & $010 ? 0$ & $0 ? 00 ?$ & 11002 & $\begin{array}{lll}11 & 1\end{array}$ & 11 & $11 ? 21$ & $1 ? ?$ & 1 ? \\
\hline 43. †Thymallus & 31111 & 12010 & 11010 & 010000 & 00100 & 11002 & 11 & 11 & 11121 & 111 & 1 ? \\
\hline 44. $\dagger$ Tischlingerichthys & $21 ? 10$ & $1 ? 00 ?$ & $? 1000$ & $010 ? ?$ & $0 ? 00 ?$ & $1 ? 002$ & 11 & $1 ?$ & ???21 & ??? & 1 ? \\
\hline 45. Umbra & 31111 & & $110 \div 0$ & 01000 & 01000 & $? 1002$ & 11 & 11 & 11121 & 111 & 11 \\
\hline 46. †Varasichthys & & & 00000 & 01110 & $0 ? 00 ?$ & $0100 \% ?$ & $\begin{array}{lll}11 & 1\end{array}$ & 11 & $? 1 ? 21$ & $1 ? ?$ & $1 ?$ \\
\hline 47. †Vinctifer & $3 ? 1 ? 1$ & 03100 & 011010 & $1000 ?$ & $0 ? 00 ?$ & 10002 & $10 / 10$ & 01 ? & $? ? 001$ & 101 & $2 ?$ \\
\hline
\end{tabular}

type species of $\dagger$ Anaethalion ( $\dagger$ A. angustus) was included as were $\dagger A$. zapporum and Elops and Megalops. This analysis confirms that the new species is an elopomorph, but it does not clarify its assignment within $\dagger$ Anaethalion (see below).

\section{Second cladistic analysis: $\dagger$ Anaethalion, $\nmid$ Elopso- molos, Elops, and Megalops}

The second cladistic analysis investigates the phylogenetic relationships among members of $\dagger$ Anaethalion, $\dagger$ Elopsomolos, and of the genera Elops and Megalops. This analysis is based on 30 characters (see Appendix 2 and Table 2) and 13 taxa of which 10 are ingroup taxa. The trees are rooted using user-specified outgroup methods, but there is no difference in the arrangement of the elopomorphs when using different outgroup methods.

The consensus tree of 105 equally parsimonious trees at 41 evolutionary steps is shown in Figure 22. Each tree has a consistency index of 0.732 and the homoplasy index is 0.268 . The ingroup taxa share five uniquely derived characters at Node A: broad mesethmoid carrying an ethmoidal commissure that penetrates and passes through the whole width of the bone; compound neural arch formed in cartilage over preural centrum 1 and 'first' ural centrum; para- 


\begin{tabular}{|c|c|c|c|}
\hline & $181-185$ & $186-190$ & 191 \\
\hline 1. †Allothrissops & $? 1000$ & 00000 & 0 \\
\hline 2. Amia calva & 00000 & 00000 & 0 \\
\hline 3. $\uparrow$ Amia pattersoni & $? ? 000$ & 00000 & 0 \\
\hline 4. †An. angustus & $? 1000$ & $0 ? 000$ & 0 \\
\hline 5. $\dagger$ An. zapporum & $? ? 000$ & $0 ? 000$ & 0 \\
\hline 6. †Ascalabos & $? 1000$ & $0 ? 110$ & 0 \\
\hline 7. $\dagger$ Ascalabothrissops & $? ? 000$ & $0 ? 110$ & 0 \\
\hline 8. $\dagger$ Aspidorhynchus & $? ? 111$ & 11000 & 0 \\
\hline 9. $\dagger$ Belonostomus & $? ? 111$ & 11000 & 0 \\
\hline 10. Chanos & 11000 & 00000 & 0 \\
\hline 11. Denticeps & $? 1000$ & 00000 & 0 \\
\hline 12. †Diplomystus & $? 1000$ & 00000 & 0 \\
\hline 13. †Domeykos & $? ? ? 00$ & 00000 & 0 \\
\hline 14. †Engraulis & 11000 & 00000 & 0 \\
\hline 15. Elops & 11000 & 00000 & 0 \\
\hline 16. †Erichalcis & $? ? 000$ & $0 ? ? 00$ & 0 \\
\hline 17. Esox & 01000 & 00000 & 0 \\
\hline 18. †Gordichthys & $? 1000$ & $0 ? ? ? 0$ & 0 \\
\hline 19. Hiodon & 11000 & 00000 & 0 \\
\hline 20. Heterotis & $? 1000$ & 00000 & 0 \\
\hline 21. †Humbertia & $? 10000$ & $0 ? 000$ & 0 \\
\hline 22. †Hypsocormus & $? ? 0000$ & 00001 & 1 \\
\hline 23. $\nmid$ Leptolepis coryp. & $? 1000$ & 00000 & 0 \\
\hline 24. Lepisosteus & 00000 & 10000 & 0 \\
\hline 25. $\dagger$ Lep. haertesi & $? ? 000$ & $0 ? 000$ & 0 \\
\hline 26. †Lep. sprattiformis & $? 1000$ & 00000 & 0 \\
\hline 27. †Luisichthys & $? ? 000$ & 00000 & 0 \\
\hline 28. $†$ Lycoptera & $? ? 000$ & $0 ? 000$ & 0 \\
\hline 29. Megalops & 11000 & 000000 & 0 \\
\hline 30. †Mesturus & $? 0000$ & $1 ? 000$ & 0 \\
\hline 31. †Obatchthys & ????? & $1 ? ? 00$ & 0 \\
\hline 32. Oncorhynchus & 11000 & 00000 & 0 \\
\hline 33. Opsariichthys & 11000 & 00000 & 0 \\
\hline 34. †Orth. leichi & $? ? 000$ & $0 ? 000$ & 0 \\
\hline 35. †Orth. hoelli & $? 1000$ & $0 ? 000$ & 0 \\
\hline 36. †Pachycormus & $? ? 000$ & 00001 & 1 \\
\hline 37. †Pachythrissops & $? ? 000$ & $0 ? 000$ & 0 \\
\hline 38. †Phol bechei & $? ? 000$ & 00000 & 0 \\
\hline 39. †Protoclupea & $? ? 000$ & $0 ? 000$ & 0 \\
\hline 40. $†$ Santanaclupea & $? ? 000$ & 00000 & 0 \\
\hline 41. TTharsis & $? 1000$ & 00000 & 0 \\
\hline 42. Thrissops & $? ? 000$ & $0 ? 000$ & 0 \\
\hline 43. $\uparrow$ Thymallus & 11000 & 00000 & 0 \\
\hline 44. $\nmid$ Tischlingerichthys & $? ? 000$ & 00000 & 0 \\
\hline 45. Umbra & 01000 & 00000 & 0 \\
\hline 46. +Varasichthys & $? 2000$ & 00000 & 0 \\
\hline 47. tVinciffer & $? 11111$ & 11000 & 0 \\
\hline
\end{tabular}
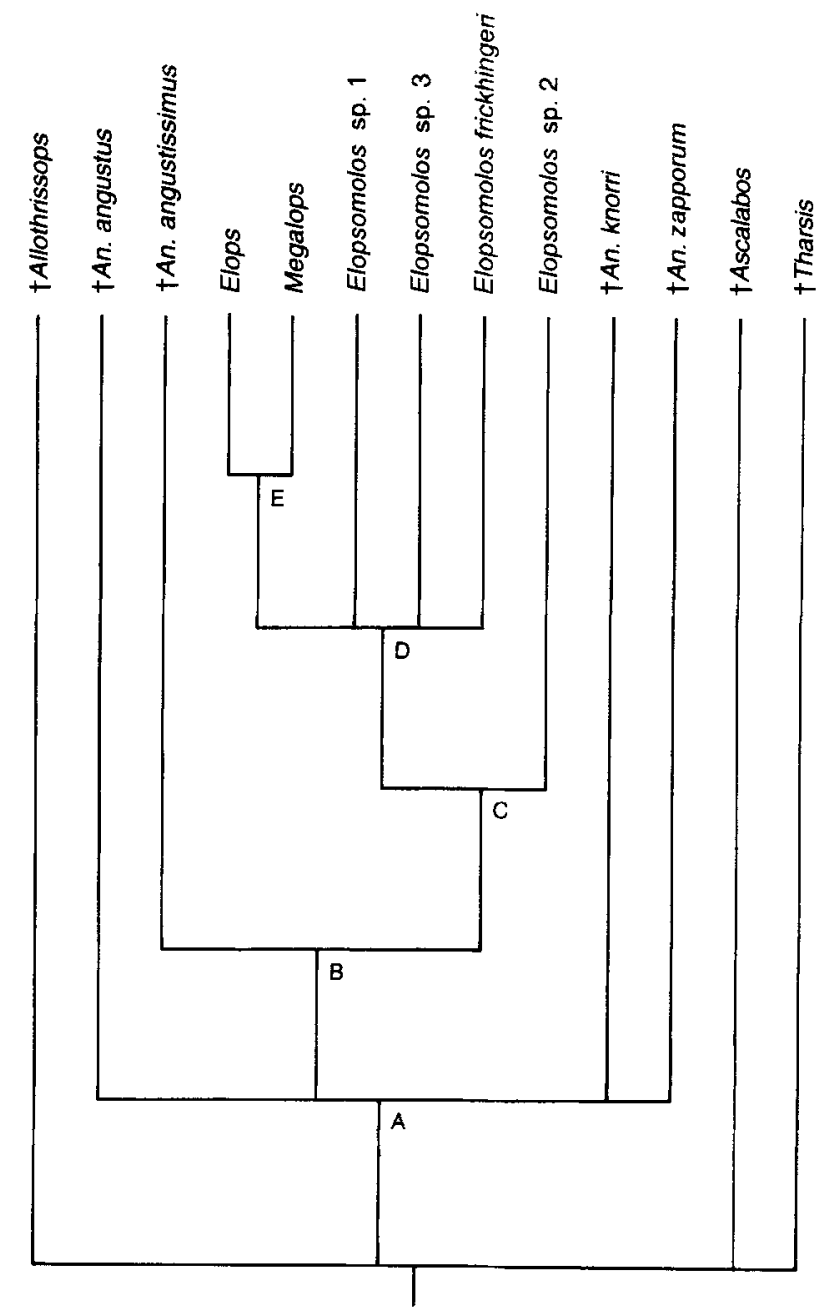

Fig. 22. Hypothesis of phylogenetic relationships of some fossil $(\dagger)$ and extant elopiforms based on the consensus tree of 105 trees at 41 evolutionary steps (using 30 characters: for characters and their coding see Table 2 and Appendix 2). $\dagger$ Tharsis, †Ascalabos, and $†$ Allothrissops are used as outgroup. Characters interpreted as uniquely derived are indicated with an asterisk $(*)$. Synapomorphies supporting nodes are: Node A: 2[1]*, 12[1], 15[1]*, 21[1], 24[1]*, 25[1]*, and 26[1]*. Node B: $7[1]^{*}$ and $8[1]^{*}$. Node C: $17[1], 19[1]$, and 20[1]. Node D: $10[1]^{*}, 14[1], 27[1], 28[1]^{*}$, and $29[1]^{*}$. Node E: $1[1]^{*}, 3[1]^{*}, 4[1]^{*}, 6[1]^{*}, 9[1]^{*}$, and $11[1]$

Table 2

Data matrix of Taxa Set representing 30 characters belonging to fossil ( $\dagger$ ) and extant elopiforms. 0, plesiomorphic state: 1. apomorphic state; ?, unclear, owing the preservation of the specimens. An.: Anaethalion.

\begin{tabular}{|c|c|c|c|c|c|c|c|c|c|}
\hline \multirow[b]{2}{*}{ 1. $\dagger$ Allothrissops } & \multirow{2}{*}{$\frac{1-5}{0}$} & \multirow{2}{*}{$\frac{6-10}{000000}$} & \multicolumn{2}{|c|}{$11-15$} & \multirow{2}{*}{$\frac{16-20}{100000}$} & \multicolumn{2}{|c|}{$21-25$} & \multicolumn{2}{|l|}{$26-30$} \\
\hline & & & 10 & 100 & & 00 & 000 & $\begin{array}{lllll}0 & 0 & 0 & 0\end{array}$ & \\
\hline 2. $\dagger$ An. angustus & 01000 & $\begin{array}{lllllllllllll}0 & 0 & 0 & 0 & 0\end{array}$ & $00 / 1$ & 001 & 10000 & 10 & $? 11$ & 1000 & 0 \\
\hline 3. $\nmid A n$. angustissimus & 01000 & 011100 & 01 & $00 ?$ & $? 000000$ & $? 0$ & ? 1 ? & 10000 & ? \\
\hline 4. $\dagger$ An. knorri & 01000 & 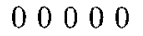 & 01 & 001 & 100000 & 10 & 111 & 1000 & 0 \\
\hline 5. $\dagger$ An zapporum & $0100 ?$ & $? 00 ? 0$ & 01 & 001 & 10000 & 10 & ? 11 & $1 ? 00$ & 0 \\
\hline 6. $†$ Ascalabos & 00000 & 00000 & 00 & 000 & 00000 & 01 & 000 & 00000 & 0 \\
\hline 7. Elops & $\begin{array}{lllll}1 & 1 & 1 & 1 & 1\end{array}$ & 11111 & 11 & 111 & $\begin{array}{lllll}1 & 1 & 1 & 1 & 1\end{array}$ & 11 & 111 & $1110 / 1$ & 0 \\
\hline 8. †Elopsomolos sp. 1 & ? $1 ? 01$ & $? \begin{array}{lllll}? & 1 & 1 & ? & 1\end{array}$ & $? ?$ & $? 1 ?$ & ????? & $? 0$ & ??? & $1 ? 1 ?$ & $?$ \\
\hline 9. Elopsomolos sp. 2 & ?1??? & ???? 0 & 01 & $0 ? 1$ & 11011 & 00 & ??? & 1??? & 0 \\
\hline 10. †Elopsomolos sp. 3 & $019 ? 01$ & $? 11101$ & 01 & $0 ?$ ? & $1 ? 1 ? ?$ & $? 0$ & $? 11$ & 1??? & ? \\
\hline 11. $†$ Elopsomolos frickhingeri & $01 ? ?$ ? & ?? $1 ? 1$ & 00 & $01 ?$ & $\begin{array}{lllllllllllll}0 & 1 & 0 & 1 & 1\end{array}$ & $1 ?$ & $1 ? 1$ & 1111 & 1 \\
\hline 12. Megalops & 11111 & 11111 & 11 & 001 & $\begin{array}{llllllllllll}0 & 1 & 0 & 1 & 1\end{array}$ & $10 / 1$ & 111 & 1111 & 1 \\
\hline 13. $†$ Tharsis & $\begin{array}{lllllllllll}0 & 0 & 0 & 0 & 0\end{array}$ & 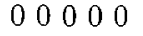 & 00 & 000 & 110000 & 00 & 000 & 0100 & 0 \\
\hline
\end{tabular}


sphenoid bearing numerous small villiform teeth: ecto- and entopterygoid covered medially with small villiform teeth; and elongate jaws bearing numerous, small, villiform teeth. Node A corresponds to the polytomy formed of $\uparrow$ Anaethalion angustus, $\dagger$ A. knorri, $\dagger A$. zapportum n. sp.. and the clade $[\dagger A$. angustissimus + more advanced elopomorphs]. Node B stands at the branching of $†$ Anaethalion angustissimus and more advanced elopomorphs. This node is supported by two uniquely derived characters: long maxilla extending laterally onto quadrate and quadratemandibular articulation below posterior margin of orbit or posterior. Node C stands at the branching of $\dagger$ Elopsomolos sp. 2 and more advanced teleosts, and Node $\mathrm{D}$ corresponds to the branching of the clade formed by [Elops + Megalops] and the polytomy formed by $\dagger$ Elopsomolos sp. 1 and sp. 3, and $\dagger$ Elopsomolos frickhingeri $\mathrm{n}$. gen. and n. sp.

This analysis confirms previous results by $\mathrm{Ar}-$ ratia (1997) that $\dagger$ Anaethalion as presently understood is paraphyletic. $\dagger$ Anaethalion angustus (the type species). $\uparrow A$. knorri, and $\uparrow A$. zapporum n. sp. form a polytomy with a clade including more advanced elopomorphs. Additionally, $\uparrow A$. angustissimus is more advanced than $\dagger A$. angustus, $\dagger A$. knorri, and $\dagger A$. zapporum $\mathrm{n}$. sp. and is the primitive sister-group of $\dagger$ Elopsomolos sp. 2 and more advanced elopomorphs.

The results of the phylogenetic analysis (Fig. 22) show that the placement of $\dagger$ Anaethalion zapporum $\mathrm{n}$. sp. in the genus $\dagger$ Anaethalion and of $\dagger$ Elopsomolos sp. 1, 2 and 3 in $\dagger$ Elopsomolos is only a formality because $\uparrow$ Anaethalion and $\dagger$ Elopsomolos should be revisited to clarify their content (work in progress by the author).

\section{Fish diversity during the Late Jurassic of Bavaria}

The localities bearing fishes in the Upper Jurassic of Bavaria are numerous (Fig. 1). Due to economic and historic reasons, the quarries from the Solnhofen Limestone such as Solnhofen. Eichstätt, Kelheim, and others around the town of Eichstätt are better known than other quarries which have been recently excavated, e.g.. Etling. in which only one fish, †Orthogonikleithrus hoelli, has been recovered (Arratia 1997), and Schamhaupten.

During recent years. new information from certain localities has been made available. Overviews of the fossiliferous content of some localities have been recently published. For instance:
Brunn (Röper et al. 1996), Hienheim (Röper \& Rothgaenger 1998), Pfalzpaint (Röper et al. 1999). and Nusplingen (Dietl \& Schweigert 1999). From other localities, descriptions of a few forms are already available. For instance: Schamhaupten (e.g., Elops-like sp. 1: Arratia 1997; $\uparrow$ Lepidotes sp.: Thies \& Zapp 1997; $\dagger$ Allothrissops sp. and $\dagger$ Ascalabothrissops voelkli $\mathrm{n}$. gen. and n. sp.: present paper) and Daiting ( $\dagger$ Daitingichthys tischlingeri: Arratia 1987a).

Table 3 illustrates the diversity of teleostean genera in Kimmeridgian and Tithonian localities in Bavaria. Only few teleosts are known from the Kimmeridgian and Tithonian Malm Z3 which can be explained by the age of the excavations. In the Solnhofen Limestone, excavations have been done over two centuries; in contrast, they have been only recently done in Schamhaupten and localities of Malm Z3. Table 3 illustrates that there are some genera apparently related to one locality and/or age, e.g., $\dagger$ Ascalabothrissops $\mathrm{n}$. gen. in the Kimmeridgian and $\nmid$ Daitingichthys and $\uparrow$ Tischlingerichthys in the Malm Z3. Others have been reported from the Kimmeridgian to Malm Z3 localities such as †Tharsis and $T$ Leptolepides (Arratia 1995). It is interesting to note that comparisons of these forms show that $\dagger$ Tharsis through time (as well as $\nmid$ Leptolepides) exhibits changes in certain morphological structures such as an increase in the number of tubules of the cephalic sensory canals (Arratia 1995). This discovery means that material from different ages has to be comparatively studied to understand the variation presented by these genera. With the exception of 1'Pholiphophorus' (not a monophyletic genus as presently understood: Arratia 2000) and $\dagger$ Anaethalion, most other genera are represented by one or two species. Among them, $\dagger$ Ascalabothrissops n. gen., $\dagger$ Daitingichthys, †Eichstaettia, †Orthogonikleithrus, and $\dagger$ Tischlingerichthys are apparently endemic to Bavaria.

The comparison between the Kimmeridgian of Schamhaupten and of Cerin shows that the last locality has more fish species than Schamhaupten (Table 4). This can be the result of the intensive excavations and research done in Cerin during many years (e.g., Saint-Seine 1949, Gaudant 1968. 1978, Wenz et al. 1993). The determination of most teleosts of Cerin has traditionally followed a monographic publication by Saint-Seine (1949); exceptions are the 'pholidophoriforms' (Gaudant 1978) and elopomorphs (Gaudant 1968). It is interesting to remark that according to the available literature, there are more simila- 
Table 3

List of Late Jurassic teleostean genera from localities of different ages from Bavaria. Undescribed taxa are not included. Number of species are indicated in brackets.

\begin{tabular}{|c|c|c|}
\hline Kimmeridgian & Tithonian Malm Z2 & Tithonian Malm Z3 \\
\hline $\begin{array}{l}\text { 'Pholidophoriformes': } \\
\quad \nmid \text { Siemensichthys }{ }^{(1)} \\
- \\
- \\
-\end{array}$ & $\begin{array}{l}\dagger \text { Siemensichthys } \\
\dagger \text { Eurycormus } \\
\dagger^{\prime} \text { Pholidophorus' } \\
\dagger \text { Pholidophoristion }\end{array}$ & $\begin{array}{l}- \\
- \\
- \\
-\end{array}$ \\
\hline $\begin{array}{l}\text { Pleuropholidae: } \\
\quad \text { - }\end{array}$ & $\dagger$ Pleuropholis & - \\
\hline $\begin{array}{l}\text { Basal teleosts: } \\
\quad- \\
\quad \text { †Tharsis (?) }\end{array}$ & $\begin{array}{l}\dagger \text { Ascalabos } \\
\dagger \text { Tharsis }\end{array}$ & - \\
\hline $\begin{array}{l}\text { Ichthyodectiformes: } \\
\quad \dagger \text { Allothrissops }{ }^{(?)} \\
\dagger \text { Ascalabothrissops n. gen. }{ }^{(1)} \\
- \\
-\end{array}$ & $\begin{array}{l}\dagger \text { Allothrissops } \\
- \\
\dagger \text { Pachythrissops } \\
\text { †Thrissops }\end{array}$ & $\begin{array}{l}- \\
- \\
-\end{array}$ \\
\hline $\begin{array}{l}\text { Elopiformes: } \\
\quad \dagger \text { Anaethalion (1) } \\
\quad \uparrow \text { Elopsomolos } \\
- \\
- \\
-\end{array}$ & $\begin{array}{l}\dagger \text { Anaethalion } \\
\dagger \text { Elopsomolos }^{(3)} \\
\dagger \text { Eichstaettia }^{(1)} \\
-\end{array}$ & $\begin{array}{l}- \\
- \\
- \\
\dagger \text { Daitingichthys }\end{array}$ \\
\hline $\begin{array}{l}\text { 'Salmoniformes': } \\
\quad \text { †Leptolepides } \\
\quad-\end{array}$ & $\begin{array}{l}\dagger \text { Leptolepides } \\
\text { †Orthogonikleithrus }\end{array}$ & $\dagger$ ¿Leptolepides ${ }^{(?)}$ \\
\hline $\begin{array}{l}\text { ?Ostariophysii: } \\
-\end{array}$ & - & $\uparrow$ Tischlingerichthys ${ }^{(1)}$ \\
\hline
\end{tabular}

Table 4

List of teleostean fishes from the Kimmeridgian localities of Schamphaupten (Germany) and of Cerin (France). Species identified with an asterik (*) also are found in the Tithonian Malm Z2 of the Solnhofen Limestone, Bavaria.

\begin{tabular}{|c|c|}
\hline Schamhaupten & Cerin \\
\hline \multicolumn{2}{|l|}{ 'Pholidophoriformes': } \\
\hline- & $\dagger$ Ankylophorus similis \\
\hline- & $\dagger$ Ankylophorus segunianus \\
\hline- & $\dagger$ Pholidorichthys inermis \\
\hline- & $\nmid$ Pholidophoristion of. P. ovatus \\
\hline tSiemensichthys siemensi & - \\
\hline \multicolumn{2}{|l|}{ Pleuropholidae: } \\
\hline- & $\dagger$ Pleuropholis thiolleri \\
\hline \multicolumn{2}{|l|}{ Basal teleosts: } \\
\hline- & $\dagger$ Ascalabos voithii $\left.{ }^{*}\right)$ \\
\hline$\dagger$ Tharsis & $\dagger$ Tharsis dubius (*) \\
\hline \multicolumn{2}{|l|}{ Ichthyodectiformes: } \\
\hline$\dagger$ Allothrissops sp. & - \\
\hline- & $\uparrow$ Allothrissops regleyi \\
\hline- & $\dagger$ Allothrissops salmoneus ${ }^{(*)}$ \\
\hline - & †Thrissops formosus ${ }^{(*)}$ \\
\hline- & $\dagger$ Thrissops cirinensis \\
\hline $\begin{array}{l}\dagger \text { Ascalabothrissops } \\
\text { voelkli } \mathrm{n} \text {. gen. and } \mathrm{n} \text {. sp. }\end{array}$ & - \\
\hline \multicolumn{2}{|l|}{ Elopiformes: } \\
\hline$\dagger$ Anaethalion zappi $\mathrm{n} . \mathrm{sp}$. & - \\
\hline- & $\dagger$ Anaethalion offinis \\
\hline- & $\dagger$ Anaethalion cirinensis \\
\hline- & $\dagger$ Anaethalion knorri ${ }^{\left({ }^{*}\right)}$ \\
\hline- & $\dagger$ Anaethalion cf. A. subovatus \\
\hline- & $\dagger$ Eoprotelops vireti \\
\hline$\dagger$ Elopsomolos sp. 1 & - \\
\hline $\begin{array}{l}\text { ‘Salmoniformes’: } \\
\dagger \text { Leptolepides }\end{array}$ & $\dagger$ Leptolepides sprattiformis \\
\hline
\end{tabular}

rities between the Kimmeridgian of Cerin and localities of Tithonian, Malm Z2 of Bavaria, than between Cerin and Schamhaupten. However, the similarities between Cerin and the localities of Malm Z2 should be revisited because the preliminary revision of specimens identified as $\dagger$ Leptolepides sprattiformis from Cerin shows that there are differences with $\dagger L$. sprattiformis from the Solnhofen Limestone (Arratia 1997). As it was mentioned above, a comparative study of tTharsis and other genera from localities of different ages is needed to clarify the content and distribution of the genera. According to available information, the genera $\nmid$ Ankylophorus, $\nmid$ Pholidophorichthys, and $\dagger$ Eoprotelops are endemic to Cerin.

The same higher taxa are common in the Kimmeridgian of Schamhaupten and Cerin and in the Tithonian of the Solnhofen Limestone. These taxa are: pleuropholids, the so-called pholidophoriforms, ichthyodectiforms, and elopomorphs.

\section{Diversification of elopiform fishes}

The elopiforms are already known from the Upper Jurassic of Europe where they are represented by six genera (Tab.5) and 15 species. None of these genera has been reported in the 
Table 5

List of genera of elopiform fishes of Jurassic. Cretaceus and Recent age. Numbers of species are indicated in brackets.

\begin{tabular}{|c|c|c|c|}
\hline Jurassic & Cretaceus & Tertiary & Recent \\
\hline \multicolumn{4}{|l|}{ Elopiformes: } \\
\hline$\uparrow$ Anathation White $1838^{(7)}$ & - & - & - \\
\hline- & †Arratiaelops Taverne. 1999 "H & - & - \\
\hline$\uparrow$ Elopsomolos & - & Elops Linnacus, $1766^{(1)}$ & $\begin{array}{l}\text { Elops Linnaeus, } \\
1766(-6)\end{array}$ \\
\hline TEichstaettia Arratia, 1987a & - & - & - \\
\hline Daitingichthys Arratia. 1987a & - & - & - \\
\hline- & $\frac{1}{\dagger}$ Davichthvs Forey $1973^{13}$ & - & - \\
\hline- & Elopoides Wenz. 1965 & - & - \\
\hline TEoprotelops Saint-Seine. $1949^{(1)}$ & - & - & - \\
\hline- & $\dagger$ Flindersichthys Longman. 1932 & & \\
\hline- & †Ichthyemidion Poyato-Ariza. 1995 (1) & - & - \\
\hline- & - & - & $\begin{array}{l}\text { Megalops Lacépede, } \\
1803^{(2)}\end{array}$ \\
\hline $\begin{array}{l}\uparrow \text { Naiathaelon Poyato-Ariza } \\
\& \text { Wenz, } 1993\end{array}$ & - & $=0$ & - \\
\hline- & - & $\grave{\dagger}$ Promegalops Casier, $1966^{(1)}$ & - \\
\hline- & - & $\dagger$ Protarpon Forey, $1973^{(2)}$ & - \\
\hline- & $\begin{array}{l}\text { iSedenhorstia White \& Moy-Thomas, } \\
1940(4)\end{array}$ & - & - \\
\hline
\end{tabular}

Cretaceous (Tab. 5), with about six genera mainly known from the Lower Cretaceous of Brazil and Lebanon (for a review see Forey 1973).

Now, elopiforms are represented only by two families with two genera, Elops and Megalops. and about eight species (Nelson 1994). It is clear then that the group, with a long history, was more broadly diversified in the past than in the present, like the situation found in other groups such as dipnoans and coelacanths among sarcopterygians.

The presence of $\dagger$ Elopsomolos in the Upper Jurassic of Europe is interesting. These forms. which share remarkable similarities with Recent Elops, are difficult to separate from the modern members of the genus. However, other $\dagger$ Elopsomolos or Elops-like forms have not been reported from the Cretaceous and Tertiary: an exception is Elops sp. from the Eocene of London Clay (Ypresian) of Sheppey, Kent, England (Woodward 1901. Forey 1973).

\section{Acknowledgements}

Thanks are due to the following institutions and individuals for permission to study fossil material under their care: D. Berman (Carnegie Museum, Pittsburgh. U.S.A.). H. Bjerring (Museum of Natural History. Stockholm. Sweden), C. H. von Daniels (Bundesanstalt für Geowissenschaften und Rohstoffe. Hannover. Germany). E. Ebbinge and J. van Veen (Teylers Museum, Haarlem. The Netherlands), L. Grande (Field Museum of Natural History. Chicago. U.S.A.). the late C. Patterson (The Natural History Museum. London. England), H. Jahnke (Institut und Museum für Geologie und Paläontologie. Georg-August-Universität. Germany). J. D. Stewart (Los Angeles County Museum. Los Angeles. Cali- fornia, U.S.A.). G. Viohl (Jura Museum, Naturwissenschaftliche Sammlungen Eichstätt, Germany), P. Wellnhofer (Bayerische Staatssammlung für Paläontologie und historische Geologie. München, Germany), F. Westphal (Institut und Museum für Geologie und Paläontologie, Tübingen, Germany). R. Wild and R. Böttcher (Staatliches Museum für Naturkunde, Stuttgart, Germany), and M. V. H. Wilson (Laboratory of Vertebrate Paleontology, Department of Biological Sciences. University of Alberta, Edmonton, Canada).

I am very thankful to Mr. J.-P. Mendau (Museum für Naturkunde der Humboldt-Universität, Berlin) for his valuable help with the illustrations based on my original drawings and Mrs. W. Harre (Museum für Naturkunde der Humboldt-Universitat. Berlin) for preparing the photographs.

My special thanks to M. V. H. Wilson, Edmonton, Alberta, Canada. L. P. Taverne. Brussels. Belgium, and H.-P. Schultze, Berlin, Germany, for reviewing the manuscript. H.-P. Schultze translated the abstract into German.

\section{References}

Agassiz. L. 1833-44. Recherches sur les Poissons Fossiles. 5 vols.. 1420 pp.. with supplements, Petitpierre, Neuchâtel et Soleure.

Arratia. G. 1987a. Anaethalion and similar teleosts (Actinopterygii, Pisces) from the Late Jurassic (Tithonian) of southern Germany and their relationships. - Palaeontographica A 200: 1-44.

- 1987b. Orthogonikleithrus leichi n. gen. et sp. (Pisces, Teleostei) from the Late Jurassic of Germany. - Paläontologische Zeitschrift 61: 309-320.

- 1991. The caudal skeleton of Jurassic teleosts; a phylogenetic analysis. In Chang M.-M., Liu Y.-H. \& Zhang G.-R. (eds). Early Vertebrates and Related Problems in Evolutionary Biology: 249-340, Science Press, Beijing.

- 1992. Development and variation of the suspensorium of primitive Catfishes (Teleostei: Ostariophysi) and their phylogenetic relationships. - Bonner zoologische Monographien 32: $1-149$.

1995. Temporal sequence and morphological variation in Jurassic fishes of southern Germany. - II International Symposium on Lithographic Limestones. Ed. Universidad Autónoma de Madrid: 15-18.

- 1996. Reassessment of the phylogenetic relationships of certain Jurassic teleosts and their implications on tele- 
ostean phylogeny. In Arratia, G. \& Viohl, G. (eds). Mesozoic Fishes - Systematics and Paleoecology: 219-242, Verlag Dr. F. Pfeil, München.

- 1997. Basal teleosts and teleostean phylogeny. - Palaeo Ichthyologica 7: 1-168.

- 1999. The monophyly of Teleostei and stem-group teleosts. Consensus and disagreements. In Arratia, G. \& Schultze, H.-P. (eds). Mesozoic Fishes 2 - Systematics and Fossil Record: 265-334, Verlag Dr. F. Pfeil, München.

- 2000. New teleostean fishes from the Jurassic of southern Germany and the systematic problems concerning the 'pholidophoriforms'. - Paläontologische Zeitschrift 74: $113-143$.

Arratia, G. \& Gayet, M. 1995. Sensory canals and related bones of Tertiary siluriform crania from Bolivia and North America and comparison with Recent forms. Journal of Vertebrate Paleontology 15(3): 482-505.

Arratia, G. \& Schultze, H.-P. 1987. A new halecostome (Actinopterygii, Osteichthyes) from the Late Jurassic of Chile and its relationships. - Dakoterra 3: 1-13.

- 1990. The urohyal: Development and homology within osteichthyans. - Journal of Morphology 203: 247-382.

- 1991. Development and homology of the palatoquadrate in osteichthyans. - Journal of Morphology 208: 1-81.

- 1992. Reevaluation of the caudal skeleton of certain actinopterygian fishes: III. Salmonidae. Homologization of caudal skeletal structures. - Journal of Morphology 214: $187-249$.

- 1999. Semionotiform fish from the Upper Jurassic of Tendaguru (Tanzania). - Mitteilungen aus dem Museum für Naturkunde in Berlin, Geowissenschaftliche Reihe 2: 135-153.

Blainville, H. D. de 1818. Sur les ichthyolites ou les poissons fossiles. Nouveau Dictionnaire d'Histoire Naturelle. Nouvelle Édition 27: 310-395.

Bardack, D. 1965. Anatomy and evolution of chirocentrid fishes. - The University of Kansas Paleontological Contributions Vertebrata, Article 10: 1-88.

Bardack, D. \& Sprinkle, D. 1969. Morphology and relationships of saurocephalid fishes. - Fieldiana, Geology 16: $297-340$.

Biese, W. 1927. Ueber einige Pholidophoriden aus den lithographischen Schiefern Bayerns. - Neues Jahrbuch für Mineralogie, Geologie und Paläontologie 58: 50-100.

Bonaparte, C. L. J. L. 1846. Osservazoni sullo stato della Zoologica in Europei in quanto ai Vertebrati nell'anno: 51 pp., Firenze.

Brito, P. 1997. Révision des Aspidorhynchidae (Pisces, Actinopterygii) du Mésozoïque: ostéologie, relations phylogénétiques, donnés environmentales et biogéographiques. - Geodiversitas 19(4): 681-772.

Casier, E. 1966. Faune ichthyologique du London Clay. XIV + 496 pp., British Museum of Natural History, London.

Chen X.-Y. \& Arratia, G. 1994. Olfactory organ in Acipenseriformes and comparison with other actinopterygians: patterns of diversity. - Journal of Morphology 222: $241-267$.

Dietl, G. \& Schweigert, G. 1999. Nusplinger Plattenkalk. Eine tropische Lagune der Jura-Zeit. - Stuttgarter Beiträge zur Naturkunde, Serie C, 45: $64 \mathrm{pp}$.

Eastman, C. R. 1914. Catalog of the fossil fishes in the Carnegie Museum. Part 4. Descriptive catalog of the fossil fishes of the lithographic stone of Solnhofen, Bavaria. Memoirs of the Carnegie Museum 6: 389-423.

Farris, J. S. 1982. Outgroups and parsimony. - Systematic Zoology 31: 328-334.

Fink, S. \& Fink, W. 1981. Interrelationships of ostariophysan fishes (Teleostei). - Zoological Journal of Linnean Society of London 72: 297-358.

- 1996. Interrelationships of ostariophysan fishes. In Stiassny, M. L. J., Parenti, L. R. \& Johnson, G. D. (eds). Interrelationships of Fishes: 209-249, Academic Press, San Diego.
Forey, P. L. 1973. A revision of the elopiform fishes, fossil and Recent. - Bulletin of the British Museum of Natural History, Geology, Supplement 10: $1-222$.

Gaudant, J. 1968. Contribution à une révision des Anaethalion de Cerin (Ain). - Bulletin du Bureau Régional de la Géologie et des Mines 4(1): 96-115.

- 1978. Essai de révision taxonomique des "Pholidophortu" (Poissons actinoptérygiens) du Jurassique supérieur de Cerin (Ain). - Nouvelles Archives du Muséum d'Histoire naturelle de Lyon, fasc. 16: 101-121.

Grande, L. 1985. Recent and fossil clupeomorph fishes with materials for revision of the subgroups of clupeids. Bulletin of the American Museum of Natural History 181: $231-272$.

Grande, L. \& Bemis, W. 1998. A comprehensive phylogenetic study of amiid fishes (Amiidae) based on comparative skeletal anatomy. An empirical search for interconnected patterns of natural history. - Journal of Vertebrate Paleontology 18, supplement 1, Memoir 4: $1-690$.

Greenwood, P. H., Rosen, D. E., Weitzman, S. H. \& Myers, G. S. 1966. Phyletic studies of teleostean fishes, with a provisional classification of living forms. - Bulletin of the American Museum of Natural History 131: 339-456.

Hennig, W. 1966. Phylogenetic Systematics. 263 pp., University of Illinois Press, Urbana.

Jessen, H. 1972. Schultergürtel und Pectoralflosse bei Actinopterygiern. - Fossils and Strata 1: 1-101.

Johnson, G. D. \& Patterson, C. 1996. Relationships of lower euteleostean fishes. In Stiassny, M. L. J., Parenti, L. R. \& Johnson, G. D. (eds). Interrelationships of Fishes: 251-332, Academic Press, San Diego.

Jollie, M. 1962. Chordate Morphology. XIV + 478 pp., Rheinhold Books, New York.

Kluge, A. G. 1985. Ontogeny and phylogenetic systematics. - Cladistic 1(1): 3-28.

Kluge, A. G. \& Farris, J. S. 1969. Quantitative phyletics and the evolution of anurans. - Systematic Zoology 18: 1-32.

Knorr, G. W. 1755. Sammlung von Merckwürdigkeiten der Natur- und Alterhümer des Erdbodens. Nürnberg.

Lacépede, B. G. E. 1803. Histoire naturelle des poissons. Vol. 5: 803 pp., Paris.

Lauder, G. V. \& Liem, K. 1983. The evolution and interrelationships of the actinopterygian fishes. - Bulletin of the Museum of Comparative Zoology, Harvard University 150: 95-197.

Lecointre, G. \& Nelson, G. J. 1996. Clupeomorpha, sistergroup of Ostariophysi. In Stiassny, M. L. J., Parenti, L. R. \& Johnson, G. D. (eds). Interrelationships of Fishes: 193-207, Academic Press, San Diego.

Li G.-Q. \& Wilson, M. V. H. 1996. Phylogeny of Osteoglossomorpha. In Stiassny, M. L. J., Parenti, L. R. \& Johnson, G. D. (eds). Interrelationships of Fishes: 163-174, Academic Press, San Diego.

Linnaeus, C. 1766. Systema naturae sive regna tria naturae, secundum classes, ordiner, genera, species, cum characterikus, differentiis, synonymis, locis. $-12^{\text {th }}$ ed., vol. 1 (pt. 1): 1-538, Laurenti Salvii, Holmiae.

Longman, H. A. 1932. A new Cretaceous fish. - Memoirs of the Queensland Museum 10: 89-97.

Maddison, W. P., Donoghue, M. \& Maddison, D. R. 1984. Outgroup analysis and parsimony. - Systematic Zoology 37: $106-141$.

Mainwaring, A. J. 1978. Anatomical and systematic revision of the Pachycormidae, a family of Mesozoic fossil fishes. - Unpublished Doctoral thesis, 127 pp., Westfield College, London.

Maisey, J. 1991. Santana Fossils. An Illustrated Atlas. 459 pp. T.F.H. Publications Inc., Neptune, New Jersey.

Münster, G. von 1834. Mittheilungen, an Professor Bronn gerichtet. - Neues Jahrbuch für Mineralogie, Geognosie, Geologie und Petrefaktenkunde 1834: 538-542. 
- 1839a. Über einige Versteinerungen in den lithographischen Schiefern von Solnhofen. - Neues Jahrbuch für Mineralogie. Geognosie. Geologie und Petrefaktenkunde 1839: $677-682$

- 1839b. Ascalabos voithii. - Beiträge zur PetrefactenKunde 2: $112-114$

- 1842. Beiträge zur Kenntniss einiger neuen seltenen Versteinerungen aus den lithographischen Schiefern in Baiern. - Neues Jahrbuch für Mineralogie. Geognosie. Geologie und Petrefaktenkunde 1842: 35-64.

Nelson. G. J. 1969. Infraorbital bones and their bearing on the phylogeny and geography of osteoglossomorph fishes. - American Museum Novitates 2394: 1-37.

Nelson. J. S. 1994. Fishes of the World. 3rd ed.: XIII +600 pp., J. Wilcy \& Sons. Inc.. New York. Chichester. Brisbane, Toronto. Singapore.

Nybelin, O. 1963. Zur Morphologie und Terminologie des Schwanzskelettes der Actinopterygier. - Arkiv för Zoologi, Serie 2. 15: $485-516$

- 1964. Versuch einer taxonomischen Revision der jurassischen Fisch-Gattung Thrissops Agassiz. - Göteborgs kungliga vetenskaps-ochvitterhets Samhälle Handligar. Serie B, 9: 351-432.

- 1967. Versuch einer taxonomischen Revision der Anaethalion-Arten des Weissjura Deutschlands. - Acta Regiae Societatis scientiarum et litterarum Gothoburgensis. Zoologica 2: 1-53.

- 1971. On the caudal skeleton in Elops with remarks on other teleostean fishes. - Acta Regiae Societatis scientiarum et litterarum Gothoburgensis. Zoologica 7: 1-52.

- 1974. A revision of the leptolepid fishes. - Acta Regiae Societatis scientiarum et litterarum Gothoburgensis. Zoologica 9: 1-202.

Patterson. C. 1973. Interrelationships of holosteans. In Greenwood. P. H.. Miles. R. S. \& Patterson. C. (eds). Interrelationships of Fishes. Zoological Journal of the Linnean Society, Supplement 1: 233-305. Academic Press London.

- 1977. The contribution of paleontology to teleostean phylogeny. In Hecht. P. C.. Goodv. P. C. \& Hecht. B. M (eds). Major Patterns in Vertebrate Evolution: 579-643. Plenum Press. New York.

Patterson, C. \& Rosen. D. E. 1977. Review of the ichthyodectiforms and other Mesozoic teleost fishes and the theory and practice of classifying fossils. - Bulletin of the American Museum of Natural History 158: 83-172.

Pinna, M. de 1996. Teleostean monophyly. In Stiassny. M. L. J., Parenti, L. R. \& Johnson. G. D. (eds). Interrelationships of Fishes: 147-162. Academic Press. San Diego.

Poyato-Ariza. F. J. 1995. Ichthyemidion a new genus for the elopiform fish 'Anaethalion idali. from the Early Cretaceous of Spain: phylogenetic comments. - Comptes Rendus de YAcadémie des Sciences. Paris 320. série Ila $133-139$.

- 1996. A revision of the ostariophysan family Chanidae. with special reference to the Mesozoic forms. - Palaeo Ichthyologica 6: 5-52.

- 1999. The elopiform fish Anaethalion angustus restored. with comments on individual variation. In Arratia. G. \& Schultze. H.-P. (eds). Mesozoic Fishes - Systematics and Fossil Record: 361-368, Verlag Dr. F. Pfeil. München.

Poyato-Ariza. F. J. \& Wenz. S. 1994. Naiathaelon okkidion n.g.n.sp. (Teleostei. Elopomorpha) from the Lower Tithonian of Canjuers (Var. France). - Geobios. Mémoirs Table Ronde International des Calcaires lithographiques. Lvon 1991: $157-166$.

Röper. M. Rothgaenger. M. \& Rothgaenger. K. 1996. Die Plattenkalke von Brunn. Sensationelle Fossilien aus dem Oberpfälzer Jura. 102 pp.. Eichendorf Verlag. Eichendorf.

Röper. M. \& Rothgaenger, M. 1998. Die Plattenkalke von Hienheim. Echinodermen - Biotope im Südfränkischen Jura. 110 pp. Eichendorf Verlag. Eichendorf.
Röper. M.. Leich, H. \& Rothgaenger, M. 1999. Die Plattenkalke von Pfalzpaint. Faszination fossiler Quallen. 119 pp.. Eichendorf Verlag, Eichendorf.

Saint-Seine, P. de. 1949. Les poissons des calcaires lithographiques de Cerin (Ain). - Nouvelles Archives du Muséum d Histoire naturelle, Lyon 2: 1-257, Lyon.

Schaeffer. B. \& Patterson, C. 1984. Jurassic fishes from the western United States, with comments on Jurassic fish distribution. - American Museum Novitates 2796: 1-86.

Schultze. H.-P. 1993. Patterns of diversity in the skulls of jawed fishes. In Hanken, J. \& Hall, B. K. (eds). The Skull. Volume 2. Patterns of Structural and Systematic Diversity: 189-254, The University of Chicago Press, Chicago and London.

- 1996. The scales of Mesozoic actinopterygians. In Arratia, G. \& Viohl. G. (eds). Mesozoic Fishes - Systematics and Paleoecology: 243-259, Verlag Dr. F. Pfeil, München.

Schultze. H.-P. \& Arsenault, M. 1985. The panderichthyid fish Elpistostege: A close relative of tetrapods? - Palaeontology 28: 293-309.

Schultze, H.-P. \& Arratia, G. 1986. Reevaluation of the caudal skeleton of actinopterygian fishes. I. Lepisosteus and Amia. - Journal of Morphology 195: 257-303.

- 1988. Reevaluation of the caudal skeleton of actinopterygian fishes. II. Hiodon, Elops and Albula. - Journal of Morphology 195: 257-303.

- 1989. The composition of the caudal skeleton of teleosts (Actinopterygii, Osteichthyes). - Zoological Journal of the Linnean Society of London 97: 189-231.

Stiassny. M. L. J. 1986. The limits and relationships of the acanthomorph teleosts. - Journal of Zoology B $\mathbf{1}$ $411-460$.

Swofford, D. 1993. PAUP: Phylogenetic Analysis Using Parsimony. Version 3.1. 264 pp., Illinois Natural History Survey, Champaign.

Taverne. L. 1975a. Sur Leptolepis (Ascalabos) voithi (Münster. G., 1839), téléostéen fossile du Jurassique supérieur de l'Europe, et ses affinités systématiques. - Biologisch Jaarboek Dodonaea 43: 233-245.

- 1975b. Considerations sur la position systématique des genres fossiles Leptolepis et Allothrissops au sein des Téléostéens primitifs et sur l'origine et le polyphylétisme des Poissons Téléostéens. - Bulletin de la Classe des Sciences. Académie Royal de Belgique, 5 série, LXX $335-371$.

- 1981. Ostéologie et affinités systématiques de Leptolepides sprattiformis (Pisces, Teleostei) du Jurassique supérieur de l'Europe. - Annales de la Société Royale Zoologique, Belgique 110: 7-28.

- 1999. Ostéologie et position systématique dí Arratiaelops vectensis gen. nov., téléostéen élopiforme du Wealdien (Crétacé inférieur) d'Angleterre et de Belgique. - Bulletin de l'Institut Royal des Sciences Naturelles de Belgique. Sciences de la Terre 69: 77-96.

Thies. D. \& Zapp. M. 1997. Ein Lepidotes (Actinopterygii, $\lceil$ Scmionotiformes) aus den Plattenkalken (Oberjura, oberes Kimmeridgium) bei Schamhaupten (Süddeutschland). - Archaeopteryx 15: 11-26.

Vetter. B. 1881. Die Fische aus dem lithographischen Schiefer im Dresdener Museum. - Mittheilungen aus dem königlich mineralogisch-geologischen und praehistorischen Museum in Dresden 4: $1-118$

Viohl. G. 1996. The paleoenvironment of the Late Jurassic fishes from the southern Franconian Alb (Bavaria, Germany). In Arratia, G. \& Viohl, G. (eds). Mesozoic Fishes - Systematics and Paleoccology: 513-528, Verlag Dr. F. Pfeil. München

Wagner. J. A. 1861. Vergleichung der urweltlichen Fauna des lithographischen Schiefers von Cerin mit den gleichnamigen Ablagerungen im fränkischen Jura. - Gelehrten Anzeiger der königlich bayerischen Akademie der Wissenschaften 48-51(1860): 390-412. 
- 1863. Monographie der fossilen Fische aus dem lithographischen Schiefer Bayerns. Zweite Abtheilung. - Abhandlungen der königlich bayerischen Akademie der Wissenschaften, mathematisch-physikalische Klasse 9, 3: 612-748.

Weitzel, K. 1933. Pachythrissops macrolepidotus n. sp., ein neuer Leptolepide aus den Solnhofener Schiefern. Paläontologische Zeitschrift 15: 22-30.

Wenz, S. 1965. Les poissons Albiens de Vallentigny (Aube). - Annales de Paléontologie, Vertébrés 51(1): 1-23.

Wenz, S. \& Brito, P. M. 1992. Première découverte de Lepisosteidae (Pisces, Actinopterygii) dans le Crétacé inférieur de la Chapada do Araripe (N-E du Brésil). Conséquences sur la phylogénie des Ginglymodi. - Comptes Rendus de l'Académie des Sciences 314, série II: $1519-1525$.

- 1996. New data about des lepisosteids and semionotids from the Early Cretaceous of Chapada do Araripe (NE Brazil): Phylogenetic implications. In Arratia, G. \& Viohl, G. (eds). Mesozoic Fishes - Systematics and Paleoecology: 153-165, Verlag Dr. F. Pfeil, München.

Wenz, S., Bernier, P., Barale, G., Bourseau, J.-P., Buffetaut, E., Gaillard, C. \& Gall, J.C. 1993. L'ichthyofaune des cal- caires lithographiques du Kiméridgian supérieur de Cerin (Aim, France). - Geobios, Memoire Special 16: 61-70.

White, E. I. 1938. The generic name Aethalion. - Annals and Magazine of Natural History (11), 2: 319.

White, E. I. \& Moy-Thomas, J. A. 1940. Notes on the nomenclature of fossil fishes - Part III, Homonyms M-Z. Annals and Magazine of Natural History 7: 395-400.

Wiley, E. O. 1981. Phylogenetics. The Theory and Practice of Phylogenetic Systematics. 439 pp., J. Wiley and Sons, New York.

Woodward, A. S. 1895. Catalogue of the Fossil Fishes in the British Museum (Natural History). - Part 3 (Pholidophoridae): 446-478, Trustees of the British Museum of Natural History, London.

- 1901. Catalogue of the Fossil Fishes in the British Museum (Natural History). - Part 4: XXXVIII + 636 pp. Trustees of the British Museum of Natural History. London.

- 1919. The fossil fishes of the English Wealden and Purbeck Formation. Part 3. - Palaeontological Society. Monographs, London: 105-148.

\section{Appendix 1: List of characters}

The phylogenetic relationships of certain teleosts (Fig. 21) are based on the features listed below. [0] represents the plesiomorphic character state and [1], [2], [3], and [4] the apomorphic character states. The outgroup used to polarize characters includes Amia calva, $\dagger$ A. pattersoni, $\dagger$ Dapedium, $\dagger$ Mesturus, Lepisosteus spp., and $\dagger$ Obaichthys following Arratia's (1999) phylogenetic hypotheses. The coding of characters of $†$ Amia pattersoni is based on the description by Grande \& Bemis (1998) and that of †Obaichthys follows Wenz \& Brito $(1992,1996)$.

Characters 1 to 187 are from Arratia (1999), and characters 188 to 191 are new. For explanation of characters and their codings see Arratia (1997: 107-141, 1999: 281-313).

1. Ethmopalatine ossification in the floor of nasal capsule articulating with autopalatine: [0] absent; [1] present.

2. Two paired endoskeletal ethmoidal ossifications: [0] absent; [1] present.

3. Postparietal (= so-called parietal) bones: [0] independent; [1] fused to each other; [2] fused with other skull bones. (Modified from Arratia 1999.)

4. Supraoccipital bone: [0] absent; [1] confined to occipital region; [2] extending forward in roof of otic region. (Modified from Patterson 1977.)

5. Basisphenoid: [0] present; [1] absent.

6. Sutures between all cartilage bones in the braincase retained throughout life, rather than being lost ontogenetically: [0] absent; [1] present. (Patterson \& Rosen 1977.)

7. Suture between parietal bones (= so-called frontals) smooth (sutura harmonica); [0] present; [1] absent.

8. Large orbitosphenoid bone: [0] absent; [1] present.

9. Orbitosphenoid bone partially or completely reaching the parasphenoid, ventrally: [0] absent; [1] present.

10. Parasphenoid: [0] with small teeth; [1] toothless; [2] with large teeth.

11. Long parasphenoid extending posterior to basioccipital; [0] absent; [1] present.

12. Ossified aortic canal: [0] present; [1] absent.

13. Canals for occipital arteries in basioccipital bone: [0] present; [1] absent.

14. Spiracular canal: [0] developed; [1] greatly reduced; [2] absent.

15. Anterior myodome: [0] as a median compartment; [1] paired; [2] absent.

16. Myodome: [0] bone-enclosed; [1] opens posteriorly, beneath basioccipital. (Patterson 1977.)

17. Recessus lateralis: [0] absent; [1] present.

18. Otophysic connection involving a diverticulum of the swimbladder that penetrates the exoccipital and extends into the prootic within the lateral wall of the braincase: [0] absent; [1] present. (Patterson \& Rosen 1977, Grande 1985.)

19. Pre-epiotic fossa: [0] absent; [1] present.

20. Foramen for glossopharyngeal nerve in exoccipital: [0] absent; [1] present. (Patterson \& Rosen 1977.)

21. Foramen for vagus nerve placed in posterolateral face of exoccipital alone: [0] absent; [1] present.

22. Cephalic sensory canal components: [0] continuous; [1] interrupted between them.

23. Cephalic sensory canals with: [0] branched tubules; [1] simple tubules; [2] reduced tubules.

24. Antorbital bone carrying a bony enclosed portion of the infraorbital sensory canal: [0] antorbital bone absent; [1] present; [2] absent.

25. An ethmoidal commissure that penetrates and passes through the whole width of a broad mesethmoid: [0] absent: [1] present.

26. Middle pit-line groove crossing the dermopterotic (or pterotic): [0] present; [1] absent.

27. Supratemporal commissure (primitively) passing through postparietals or through postparietals (= so called parietal) and supraoccipital: [0] absent; [1] present. (Patterson \& Rosen 1977, Grande 1985.) 
28. Ankylosis or fusion between the mesial extrascapula and postparietal alone or postparietal (= so called parietal) and supraoccipital: [0] absent: [1] present. (Arratia \& Gayet 1995: modified from Lecointre \& Nelson 1996.)

29. A narrow tube-like infraorbital 1 or a broad antorbital plus infraorbital 1 combined with enlarged bone(s) representing the third and fourth and / or fourth and fifth of other teleosts: [0] absent; [1] present.

30. Fourth and fifth infraorbital bones: [0] separate: [1] fused forming an expanded bone.

31. Suborbital bone(s): [0] one or more: [1] none.

32. Supraorbital bone(s): [0] two or more: [1] one: [2] none: [3] fused with other bone forming the supraorbitodermosphenotic.

33. Large supraorbital bone with expanded anteroventral portion: [0] absent; [1] present.

34. Comma-shaped antorbital bone: [0] absent: [1] present.

35. Toothed dermopalatine bone(s): [0] present: [1] absent.

36. Autopalatine bone: [0] ossifies late in ontogeny: [1] ossifies early in ontogeny; [2] autopalatine absent. (Arratia \& Schultze 1991.)

37. Parasagittal elongation of suspensorium due to separation between quadrate and hyomandibula and elongation of symplectic: [0] absent: [1] present. (Fink \& Fink 1981. Arratia 1992.)

38. Partial parasagittal elongation of the suspensorium due to enlargement of quadrate and symplectic and the separation between the long and narrow ventral part of the hyomandibula and symplectic: [0] absent; [1] present.

39. Elongation of the suspensorium due to the ventroposterior inclination of the hyomandibula: [0] absent; [1] present.

40. Hyomandibular bone with a preopercular process at its posterior margin: [0] absent; [1] present.

41. Elongate jaws bearing numerous villiform teeth: [0] absent: [1] present.

42. Upper and lower jaws: [0] with teeth: [1] without teeth.

43. Very broad, concave-convex premaxilla: [0] absent: [1] present. (Poyato-Ariza 1996.)

44. Articular process of maxilla very long and irregularly shaped: [0] absent: [1] present.

45. Dentated maxilla: [0] present: [1] absent: [2] other condition: maxilla and infraorbital bones fused.

46. Supramaxilla(ae) dorsal to the dorsal margin of maxilla: [0] present: [1] absent: [2] other condition: placed posteriorly to maxilla.

47. Quadrate-mandibular articulation: [0] posterior to orbit: [1] placed below the posterior half of orbit; [2] below anterior half of orbit; [3] anterior to orbit.

48. Retroarticular bone: [0] included in the joint facet for quadrate: [1] excluded from the joint facet for quadrate; [2] retroarticular bone absent.

49. Articular bone: [0] not fused to angular and retroarticular; [1] fused with angular and retroarticular bones; [2] fused with angular; [3] partially fused with anguloretroarticular late in ontogeny.

50. Postarticular process of lower jaw: [0] poorly developed: [1] well developed.

51. Notch in the deep dorsal ascending margin of the dentary: [0] absent: [1] present.

52. Posterior opening of the mandibular sensory canal: [0] placed medial or posterior; [1] placed lateral to the angular portion of the jaw

53. Posterior section of the mandibular canal: [0] present: [1] absent.

54. Mandibular canal enclosed in bone along the whole jaw: [0] present: [1] absent.

55. Elongate posteroventral process of quadrate: [0] absent: [1] present. (Arratia \& Schultze 1991.)

56. Gular plate: [0] present: [1] absent.

57. Hyoidean artery: [0] not piercing the hypohyals: [1] piercing the hypohyals: [2] piercing ventral hypohyal.

58. Basibranchials $1-3$ and basihyal cartilages overlain by median tooth plate(s): [0] absent; [1] present. (Lauder \& Liem 1983.)

59. Branchial spiracle: [0] absent: [1] present.

60. Pharyngobranchials: [0] two ossified elements and a cartilaginous one bearing tooth plate(s); [1] three ossified elements and a cartilaginous one bearing tooth-plate(s): [2] other condition: pharyngobranchials 1 and 4 missing.

61. Pharyngobranchial 1 in large individuals: [0] rod-like or elongate: [1] with a bony, broad base articulating with epibranchial 1 and bearing a short dorsal process: [2] with a cartilaginous or bony narrow base, keeping mainly or only the elongate ossified dorsal process: [3] pharyngobranchial 1 absent.

62. Tooth-plate of last pharyngobranchial bone formed by: [0] confluence of many tooth-plates; [1] growth of one toothplate; [2] cartilaginous pharyngobranchial 4 of teleosts missing.

63. Tooth-plates associated with pharyngobranchials 1-3: [0] absent: [1] present: [2] another condition: pharyngobranchial 1 absent.

64. Suprapreopercle: [0] absent: [1] present.

65. Ventroposterior region of preopercle: [0] narrow or slightly expanded; [1] broadly expanded.

66. Preopercular sensory canal with most tubules in ventral limb reaching ventral and ventroposterior margins of the bone: [0] absent: [1] present.

67. Preopercular sensory canal with four or fewer short and simple tubules placed in the ventral limb of the bone: [0] absent; [1] present.

68. Distinctively enlarged preopercle: [0] absent; [1] present.

69. Irregular parallelogram. or oval. or kidney-shaped opercular bone: [0] absent; [1] present. (Li \& Wilson 1996.)

70. Opisthocoelus centra with a convex anterior articular surface and a concave posterior articular surface: [0] absent; [1] present.

71. Each vertebral centrum of the caudal region of adult individuals formed by: [0] mineralized chordacentrum and arcocentra: [1] chordacentrum and basal part of arcocentra surrounded by autocentrum: [2] basal part of arcocentra surrounded by autocentrum.

72. Midcaudal vertebral autocentra: [0] absent: [1] thin and smooth: [2] thick and sculptured; [3] thick and smooth. (Modified from Arratia 1991, 1997.)

73. Autocentrum of midcaudal vertebrac: [0] absent: [1] without cavities for adipose tissue; [2] with cavities for adipose tissue.

74. Midcaudal autocentra: [0] absent: [1] not constricting the notochord; [2] strongly constricting the notochord.

75. Neural arches of the abdominal region: [0] unfused to the centra: [1] fused, except for the first five or six; [2] fused to the autocentra. 
76. Dorsomedial portions of the anterior neural arches expanded and abutting against each other and the posterior margin of the exoccipital: [0] absent; [1] present. (Fink \& Fink 1981.)

77. Neural arches of most abdominal vertebrae: [0] with separate halves of the neural arch; [1] with fused halves of the neural arch forming a median neural spine.

78. Supradorsal cartilages in abdominal vertebrae: [0] present; [1] absent.

79. Anterior pleural rib, on third vertebra, is distinctly larger than the next few ribs: [0] absent: [1] present. (Fink \& Fink 1996.)

80. Neural spines of caudal region: [0] paired; [1] unpaired.

81. Interhaemal bones: [0] present; [1] absent.

82. The first supraneural anterior to the neural spine of vertebra 1 develops independently, and the remainder differentiate in rostral and caudal gradients from a focus midway between the occiput and dorsal fin origin: [0] absent; [1] present. (Johnson \& Patterson 1996.)

83. In adult individuals, elongate, solid epineural processes of neural arch: [0] absent; [1] present; [2] another condition: a separate bone joined to the neural arch by a ligament.

84. In adult individuals, last epineural processes of neural arch belonging to caudal vertebrae: [0] absent; [1] present.

85. Epipleural intermuscular bones: [0] absent; [1] few bones in the anterior caudal region; [2] many bones developed in the abdominal and anterior caudal regions.

86. Complex epipleural bones: [0] absent; [1] present.

87. Series of dorsal intermuscular bones throughout caudal region: [0] absent; [1] present.

88. Supracleithrum with main lateral line emerging: [0] at its upper half; [1] at its posteroventral margin; [2] lateral line not running through the supracleithrum.

89. Postsupracleithum(ra): [0] absent; [1] present.

90. Postcleithra: [0] three or two; [1] four or more; [2] none.

91. Coracoid bone enlarged ventrally meeting its fellow in a midventral coracoid symphysis: [0] absent; [1] present. (Patterson \& Rosen 1977.)

92. Pectoral propterygium fused with first pectoral ray: [0] absent; [1] present. (Jessen 1972, Patterson 1977.)

93. Pectoral axillary process: [0] absent; [1] present; formed by small bony elements; [2] present; formed by an elongate bony element; [1] present; formed by modified scales.

94. Pelvic axillary process: [0] absent; [1] present; formed by an elongate bone; [2] present; formed by a combination of bony element(s) and modified scales; [3] present; formed by modified scales.

95. Dorsal and anal fins posteriorly placed: [0] absent; [1] present.

96. Dorsal fin origin anterior to that of pelvic fin: [0] absent; [1] present.

97. Dorsal and anal fins acuminate: [0] absent; [1] present.

98. Anal fin long, falcate, opposed by a short, remote dorsal fin: [0] absent; [1] present. (Patterson \& Rosen 1977.)

99. First anal pterygiophore placed posterior to fourth or fifth haemal spine: [0] absent; [1] present.

100. Preural vertebrae (without preural centrum 1) of adult individuals with haemal arches: [0] autogenous; [1] laterally fused to their respective autocentra; [2] not fused laterally to their autocentra.

101. Parhypural (in adults) with haemal arch: [0] autogenous; [1] laterally fused to its autocentrum; [2] laterally unfused to its autocentrum.

102. Hypurapophysis: [0] absent; [1] present.

103. Neural spine of preural vertebrae 5-3 distally expanded by fine anterior and posterior membranous outgrowths: [0] absent; [1] present.

104. Neural spines of at least preural vertebral 4-2 with membranous outgrowths and leaf-like: [0] absent; [1] present.

105. Neural spine of preural vertebra 3: [0] inclined toward the horizontal at an angle of less than 45 degrees in relation to the dorsal margin of the centra; [1] inclined toward the horizontal at an angle of over 45 degrees.

106. Neural spine of preural centrum 2: [0] shorter than neural spine of preural centrum $3 ;[1]$ as long as neural spine of preural centrum 3; [2] neural spine absent.

107. Neural spine of preural centrum 1: [0] rudimentary or short; [1] long, close to, or reaching the dorsal margin of the body; [2] absent.

108. Neural arch on preural centrum 1: [0] present; [1] absent or atrophic.

109. Neural spine of ural centra 1 and 2 or 'first' ural centrum: [0] present; [1] absent; [2] other condition: preural centrum 1 fused with ural centrum(tra).

110. Neural arch of ural centra 1 and 2 or the 'first' ural centrum: [0] present; [1] absent; [2] other condition: fusion of elements.

111. Neural arch over 'first' ural centrum: [0] complete; [1] reduced; [2] other condition: fusion of elements.

112. A mass of cartilage, or uroneural cartilage, apparently originated by fusion of cartilaginous ural neural arches: [0] absent: [1] present.

113. A compound neural arch formed in a mass of cartilage over preural centrum 1 and ural centra: [0] absent; [1] present (Modified from Patterson \& Rosen 1977.)

114. Ural centra (originate only) as expansion of the dorsal arcualia: [0] absent; [1] present. (Schultze \& Arratia 1986, 1989.)

115. 'First' ural centrum corresponds to: [0] two separate centra or fusion of ural centra 1 and 2; [1] ural centrum 2 only: [2] ural centrum(a) fuses to preural centrum $1 ;[1]$ all elements fused.

116. 'Second' ural centrum corresponds to: [0] two or more separate centra or fusion of ural centra; [1] ural centrum 4; [2] all elements fused.

117. Number of epurals: [0] five or more; [1] three or four; [2] two; [3] one; [4] none.

118. Some preural neural arches modified as uroneural-like bones: [0] absent; [1] present.

119. Number of ural neural arches modified as uroneurals: [0] none; [1] seven or more; [2] six; [3] five or four; [4] three or less.

120. Anteriormost uroneurals present as: [0] none; [1] two or three long separate uroneurals (loss or fusion of one); [2] two long separate uroneurals (loss or fusion of two); [3] one long uroneural (loss or fusion of three); [4] one long uroneural (fusion of four).

121. All uroneurals inclined towards the horizontal, one beside the other: [0] no uroneural present; [1] present; [2] absent; [3] other condition: less than two uppermost uroneurals present. 
122. Six or seven uroneurals, the first three or four extending anteroventrally to cover the entire lateral surface of the first, second or third preural centra: [0] absent: [1] present.

123. Uppermost three uroneurals forming a series that overlaps and lies at an angle to, longer anterior ones: [0] no uroneural present; [1] absent; [2] present: [3] other condition: less than three uppermost uroneurals. (Modified from Patterson \& Rosen 1977.)

124. First uroneural reaches: [0] no uroneural present: [1] preural centrum 4 or 3; [2] preural centrum 2; [3] preural centrum $1 ;$ [4] reaching no preural cenira.

125. Two uroneurals. rather than three or four, extending forward beyond the 'second" ural centrum: [0] no uroneural present; [1] absent: [2] present: [3] other condition: one uroneural present. (Modified from Patterson \& Rosen 1977.)

126. Number of hypurals in adult individuals: [0] ten, nine, or eight; [1] seven or less: [2] all hypurals fused.

127. Only hypural 2 fused with 'first' ural centrum: [0] absent: [1] present.

128. Bases of hypurals 1 and 2: [0] not joined by cartilage in any growth stage; [1] joined by cartilage (and/or bone) in some growth stage.

129. Both hypurals 1 and 2 associated by fusion or articulation with a 'compound' centrum, apparently formed by preural centrum 1 and ural centrum(a): [0] absent: [1] present: [2] fusion of elements.

130. A space or diastema between hypurals 2 and 3: [0] absent: [1] present; [2] other condition: fusion of elements.

131. First uroneural fused with a compound centrum apparently formed by preural centrum 1 and ural centrum(a): [0] absent; [1] present.

132. Stegural: [0] absent; [1] present.

133. Membranous outgrowth of stegural covering laterally the ventral tips of epurals: [0] absent; [1] present.

134. Pleurostyle: [0] absent; [1] present.

135. Median caudal cartilages: [0] absent: [1] present.

136. Urodermals and "urodermals": [0] more than two urodermals; [1] two "urodermals"; [2] one "urodermal"; [3] none.

137. Three or more fringing fulcra preceeding the first principal caudal ray: [0] present; [1] absent.

138. Both epaxial and hypaxial basal fulcra: [0] present: [1] absent.

139. Proximity of the fulcra or dorsal procurrent rays to: [0] epurals and posterior uroneurals; [1] neural spines, epurals, and posterior uroneurals; [2] absence of structures.

140. Long dorsal segmented procurrent rays: [0] absent: [1] present.

141. Number of principal caudal rays: [0] iwenty or more: [1] nineteen: [2] less than nineteen.

142. Lower lobe of the caudal fin with: [0] no well-defined ventral lobe: [1] more than nine principal rays; [2] nine principal rays; [3] less than nine principal rays.

143. Branched rays of the caudal fin: [0] more than 16: [1] 16 or less.

144. Bases of the dorsalmost principal rays of the caudal fin crossing obliquely over the entire upper hypural series (save the last): [0] present: [1] absent.

145. Dorsal processes of the bases of the innermost principal caudal rays of upper lobe: $[0]$ absent; [1] present.

146. Principal caudal rays with elongate segments and with: [0] Z-like or step-like segmentation; [1] straight segmentation. (Modified from Arratia 1991. 1996. 1997.)

147. Abrupt dorsal flexion of the tail begins at preural centrum 1 or 'first' ural centrum: [0/ absent; [1] present; [2] fusion of elements.

148. One or more abdominal scutes. each of a single element which crosses the ventral midline of the fish: [0] absent; [1] present.

149. Dorsal scute(s) preceeding caudal fin: [0] present: [1] absent.

150. Amioid-type of scales or scales with radial structures (sensu Schultze 1996): [0] absent; [1] present.

151. Lepidosteoid-type of scales: [0] absent: [1] present.

152. Cycloid scales: [0] absent: [1] present: [2] other condition: without scales.

153. Cycloid scales posterior to the pectoral girdle with circuli crossed by transverse lines in the middle field: [0] absent; [1] present: [2] other condition: without scales.

154. Cycloid scales with crenulate posterior margin: [0] absent: [1] present: [2] other condition: without scales.

155. Leptocephalous larva: [0] absent: [1] present.

156. Narrow separation between olfactory organ and eye: $[0]$ present: [1] absent.

157. Primary olfactory lamellae bearing secondary lamellae: [0] present: [1] absent.

158. Adipose fin: [0] absent: [1] present.

159. Primary bite between parasphenoid and basihyal: [0] absent: [1] present. (Li \& Wilson 1996.)

160. Intestine coiling to left of stomach: [0] absent: [1] present. (Nelson 1969.)

161. Posterior margin of maxilla: [0] concave or at least notched: [1] convexely rounded or straight; [2] sharp. (Modified from Grande \& Bemis 1998. but polarization modified.)

162. Symplectic: [0] articulates with lower jaw: [1] does not articulate with lower jaw. (Patterson 1973.)

163. Solid perichordally ossified diplospondylous centra in adult individuals: [0] absent; [1] present.

164. Posterior margin of caudal fin convexly rounded: [0] absent: [1] present.

165. Number of ossified ural neural arches: [0] more than two: [1] two; [2] one or none.

166. Arrangements of hypurals and caudal fin rays: [0] each hypural normally articulates with one caudal ray; [1] each hypural normally articulates with a few caudal rays; [2] fusion of hypurals. (Modified from Grande \& Bemis 1998.)

167. Number of ural centra (in adults): [0] more than two: [1] two or one: [2] no ural centra. (Modified from Patterson 1977, Pinna 1996.)

168. First two hypurals supported by a single centrum: [0] absent: [1] present: [2] fusion of elements. (Modified from Patterson 1977. Pinna 1996.)

169. Only ural neural arches modified as uroneurals: [0] absent: [1] present. (Modified from Patterson 1973, 1977, Pinna 1996.)

170. Two ossified hypohyals: [0] absent: [1] present. (Arratia \& Schultze 1990.)

171. Urohyal formed as an unpaired tendon-bone: [0] absent: [1] present. (Arratia \& Schultze 1990, Pinna 1996.)

172. Hyoidean artery: [0] not piercing the hypohyal(s): [1] piercing one or both hypohyals. (Arratia \& Schultze 1990, Pinna 1996.)

173. Independent endoskeletal basihyal: [0] absent: [1] present; [2] other condition.

174. Mobile premaxilla: [0] absent: [1] probably with certain mobility: [1] present. (Modified from Patterson \& Rosen 1977, Pinna 1996.) 
175. Coronoid bones in lower jaw: [0] present; [1] absent. (Patterson 1977, Pinna 1996.)

176. Suprangular bone in lower jaw: [0] present; [1] absent.

177. Posterior myodome: [0] not extending into basioccipital (e.g., in prootic); [1] extending in basioccipital; [2] absent. (Modified from Patterson 1977, Pinna 1996.)

178. [In adults] Vomer: [0] paired; [1] unpaired. (Modified from Patterson 1977, Pinna 1996.)

179. Parietal bones (= so-called frontal) : [0] not distinct broadening between anterior and posterior parts; [1] distinctly broader posteriorly, but long and narrow anteriorly; [2] fused to other cranial bones. (Arratia \& Schultze 1987, Pinna 1996.)

180. Craniotemporal muscle: [0] absent; [1] present. (Stiassny 1986, Pinna 1996.)

181. Accessory nasal sacs: [0] absent; [1] present. (Chen \& Arratia 1994, Pinna 1996.)

182. Four proximal pectoral radials: [0] absent; [1] present. (Jessen 1972, Patterson 1977, Pinna 1996.)

183. Premaxillae forming a rostral tube that projects into the ethmoidal region: $[0]$ absent; $[1]$ present. (Brito 1997.)

184. Presence of a toothed predentary: [0] absent; [1] present. (Brito 1997.)

185. Very posterior position of the preopercular sensory canal in a peculiarly shaped preopercle: [0] absent; [1] present. (Brito 1997.)

186. Interopercular bone: [0] present; [1] absent. (Brito 1997, Arratia 1999.)

187. An occipital process formed by fusion of intercalar and autopterotic: [0] absent; [1] present. (Brito 1997.)

188. Approximately 40 vertebrae (including preural centrum 1): [0] absent; [1] present.

189. Narrow, elongate neural and haemal arches placed at the dorsal and middle regions of each centra: [0] absent; [1] present.

190. Large compound rostro-dermethmoid meeting the parietal bones (so-called frontais) posteriorly, and separating the paired premaxillae and nasal bones: [0] absent; [1] present. (Mainwaring 1978.)

191. Pectoral fin scythe-like and rays branching at their extreme ends: [0] absent; [1] present. (Mainwaring 1978.)

\section{Appendix 2}

List of characters and character states for some fossil and extant elopomorphs. Figure 22 is based on the features listed below. [0] represents the plesiomorphic character state and [1] and [2] the apomorphic character states. The outgroup used to polarize characters follows the phylogenetic hypotheses of Arratia $(1997,1999)$ and includes $\dagger$ Allothrissops, $\dagger$ Ascalabos, and $\dagger$ Tharsis. Characters 1 to 23 are from Arratia (1997: app. 1), and characters 24 to 30 are new.

1. Mesethmoid with well developped lateral processes: [0] present; [1] absent.

2. A broad mesethmoid carrying an ethmoidal commissure that penetrates and passes through the whole width of the bone: [0] absent; [1] present.

3. Lateral rostral: [0] absent; [1] present.

4. Antorbital bone elongated and placed anterior to infraorbital 1: [0] absent; [1] present.

5. Large infraorbital 1 expanded anteriorly and dorsally: [0] absent; [1] present.

6. Posterior margin of infraorbitals 3-4 not reaching anterior margin of preopercle: [0] absent; [1] present.

7. Maxilla: [0] not extending laterally onto quadrate or reaching quadrate; [1] long; extending laterally onto quadrate.

8. Quadrate-mandibular articulation: [0] below the middle of the orbit or below posterior half of orbit; [1] below the posterior margin of orbit or posterior.

9. Anterior ceratohyal fenestrated: [0] present; [1] absent.

10. Preopercle broadly expanded posteriorly: [0] absent; [1] present.

11. Number of vertebrae: [0] less than $55 ;[1]$ over 70.

12. Vertebral autocentra sculptured with numerous fine longitudinal grooves and crests (in adults): [0] absent; [1] present.

13. Midcaudal centra with neural and haema] arches laterally fused in adults: [0] present; [1] absent.

14. Cleithrum with short and sharp dorsal limb: [0] absent; [1] present.

15. A compound neural arch formed in cartilage over preural centrum 1 and 'first' ural centrum [0] absent; [1] present.

16. Parhypural (in adults) with haemal arch laterally fused to its centrum: [0] present; [1] absent.

17. Hypurapophysis: [0] absent; [1] present.

18. Neural spine of preural centrum 2 short and leaf-like: [0] absent; [1] present.

19. Number of uroneurals: [0] four or more; [1] three.

20. First uroneural anterolaterally expanded: [0] absent; [1] present.

21. The longest anterior uroneural anteriorly reaching preural centrum: [0] three; [1] two.

22. Few fringing fulcra in the dorsal lobe of the caudal fin: [0] present; [1] absent.

23. Leptocephalous larvae: [0] absent; [1] present.

24. Parasphenoid bearing numerous small villiform teeth: [0] absent; [1] present.

25. Medial views of ecto- and entopterygoid covered with small villiform teeth: [0] absent; [1] present.

26. Elongate jaws bearing numerous, small, villiform teeth: [0] absent; [1] present.

27. Numerous and ramified tubules of the preopercular sensory canal almost reaching the margin of the bone: [0] absent: [1] present.

28. Opercular and subopercular bones broadly expanded posteriorly: [0] absent; [1] present.

29. Origin of dorsal fin slightly opposite or anterior to that of pelvic fin: [0] absent; [1] present.

30. Neural spine of preural centrum 1: [0] short or absent; [1] long. 